\title{
Otoliths in situ from Sarmatian (Middle Miocene) fishes of the Paratethys. Part III: tales from the cradle of the Ponto-Caspian gobies
}

\author{
Werner Schwarzhans ${ }^{1} \cdot$ Harald Ahnelt ${ }^{2} \cdot$ Giorgio Carnevale $^{3} \cdot$ Sanja Japundžic $^{4}$. \\ Katarina Bradić $^{5} \cdot$ Andriy Bratishko ${ }^{6,7}$
}

Received: 2 June 2016/ Accepted: 16 September 2016/Published online: 10 November 2016

(C) The Author(s) 2016. This article is published with open access at Springerlink.com

\begin{abstract}
Articulated fossil fish skeletons with otoliths in situ provide a unique opportunity to link these two, otherwise independent data sets of skeletons and otoliths. They provide calibration points for otoliths also adding important information for the evolutionary interpretation of fishes. Here, we review nine articulated skeletons of gobies from the early Sarmatian of Dolje, Croatia, and Belgrade, Serbia, which were previously regarded as members of a single gobiid and a callionymid species. We found them to represent five different gobiid species belonging to five different genera, four of which are related to extant endemic Ponto-Caspian gobiid lineages. The species are: Aphia macrophthalma n.sp., Proneogobius n.gen. pullus (the only previously recognized species), Protobenthophilus n.gen. squamatus n.sp., Economidichthys triangularis (a species first described based on otoliths) and Hesperichthys n.gen. reductus $\mathrm{n}$.sp. Five specimens contained otoliths in situ and a sixth shows imprints of otoliths which unfortunately must
\end{abstract}

Editorial handling: L. Cavin and D. Marty.

\author{
Werner Schwarzhans \\ wwschwarz@aol.com \\ Harald Ahnelt \\ harald.ahnelt@univie.ac.at \\ Giorgio Carnevale \\ giorgio.carnevale@unito.it \\ Sanja Japundžić \\ Sanja.Japundzic@hpm.hr \\ Katarina Bradić \\ bradic.kaca@gmail.com \\ Andriy Bratishko \\ andrejbratishko@mail.ru
}

1 Natural History Museum of Denmark, Zoological Museum, Universitetsparken 15, 2100 Copenhagen, Denmark have been lost in the past, probably during preparation of the fossil. Together, they represent all five species recognized by skeletons, and three are linked to otolith-based species. Isolated otoliths have been reviewed from a variety of collections from Sarmatian strata in Austria, Bulgaria, Czechia, Romania and Slovakia resulting in the description of five new otolith-based species: Benthophilus? ovisulcus n.sp., Benthophilus styriacus n.sp., Protobenthophilus strashimirovi n.sp., Economidichthys altidorsalis n.sp. and Knipowitschia bulgarica n.sp. Our review demonstrates that all major endemic Ponto-Caspian gobiid lineages were already present during Sarmatian times, thereby pushing back their origin by approximately 5-10 myr in comparison to previously published dates for dichotomies. In our assessment, the origination of these lineages is linked to the early stage of separation of the Paratethys from the world oceans and the ecological changes that occurred during that time. These geological events parallel a dramatic increase in gobiid radiation and speciation, giving rise to many lineages, not all of which have persisted until today.

2 Department of Theoretical Biology, University of Vienna, Althanstrasse 14, 1090 Vienna, Austria

3 Dipartimento di Scienze della Terra, Università degli Studi di Torino, via Valperga Caluso 35, 10125 Turin, Italy

4 Department of Geology and Paleontology, Croatian Natural History Museum, Demetrova 1, 10000 Zagreb, Croatia

5 Department of Paleontology, Faculty of Mining and Geology, University of Belgrade, Kamenička 6, 11000 Belgrade, Serbia

6 Faculty of Natural Sciences, Luhansk Taras Shevchenko National University, Gogolya Sqr. 1, Starobelsk, Luhansk Region 92703, Ukraine

7 BugWare Inc., 1615 Village Square Blvd., Ste 208, Tallahassee, FL 32309, USA 
Keywords Gobiidae $\cdot$ Aphia lineage $\cdot$ Benthophilus lineage $\cdot$ Pomatoschistus lineage

\section{Introduction}

The Ponto-Caspian Basin is the scene of a highly diverse endemic evolution of fishes of the family Gobiidae. It encompasses two principal lineages, the Ponto-Caspian gobies (Thacker and Roje 2011) (Benthophilus lineage of Neilson and Stepien 2009) and a branch of the sand gobies (Thacker and Roje 2011) (Pomatoschistus lineage of Agoretta et al. 2013 and Thacker 2015) primarily represented by the genera Knipowitschia and Economidichthys. Some species of the genera Neogobius and Proterorhinus are known to be highly competitive and invasive when being displaced into environments not normally reached from the Ponto-Caspian (Dillon and Stepien 2001; Jacobs and Hoedemakers 2013). The origin and evolution of the endemic gobies of the PontoCaspian Basin in time and space have been subject of much discussion in recent ichthyological literature (Economidis and Miller 1990; Miller 1990; Huyse et al. 2004; Neilson and Stepien 2009). Neilson and Stepien (2009) commented that "the historic endemism and taxonomic diversity of the PontoCaspian neogobiins are remarkable, and knowledge of their evolutionary history may yield insight into the evolution of species flocks, factors leading to their rapid evolutionary diversification, as well as invasive success in new habitats". Hence, several of the studies made extensive use of the palinspastic geological restorations and paleogeographic reconstructions of the Paratethys (for instance from Rögl, 1999), but without any direct fossil data of gobiid fishes having been available. It has only been very recently that fossil otoliths of gobies have been described from Middle Miocene strata of the Paratethys from Kazakhstan (Bratishko et al. 2015) and Serbia (Schwarzhans et al. 2015) and were identified as related to those endemic Ponto-Caspian goby groups. These studies indicated that the origin of the endemic gobies in the Ponto-Caspian Basin was intimately connected to the geographic separation of the Paratethys from the Mediterranean and other world oceans during the Middle Miocene and thus lends support for an earlier variant of the evolutionary origin. The articulated skeletons with otoliths in situ studied herein offer new insight into this crucial period of the evolution of the Ponto-Caspian gobies, confirm the previous otolithbased results and enhance and broaden our understanding of the evolutionary history of the group.

Articulated skeletons of gobies are not uncommon in the Sarmatian of the Central and Eastern Paratethys, but they have obviously attracted limited interest in recent years and have never been comprehensively reviewed. The oldest report of gobies from the Sarmatian of the Paratethys was provided by Steindachner (1860), who described three species from a particular paleoenvironment in Austria (Gobius elatus, G. oblongus and G. viennensis). They are not part of this review and are currently being studied by Reichenbacher and Gierl in Munich. Subsequently, a number of articulated skeletal remains were collected in the late nineteenth century by Kramberger (1882) in Croatia and identified as Gobius pullus Kramberger 1882. Anđelković (1989) reported additional gobiid specimens from the Sarmatian of Serbia assigned to the species G. pullus and G. brivesi Arambourg 1927. The latter species was originally described from the Messinian of Oran, Algeria, and its presence in the Paratethyan realm seems to be unlikely (see Schwarzhans et al. 2016a, 2016b). Carnevale et al. (2006) described a gobiid from the Sarmatian of the northern Caucasus, Russia, which they identified as Pomatoschistus sp. based on otoliths in situ.

Many of the specimens originally described by Kramberger (1882) and a single specimen from the collection of Anđelković were found to contain otoliths in situ, and constitute the source of the main part of our study. Gobiid otoliths are very common in the Sarmatian (and younger) sediments of the Paratethys, often representing the most common faunal element, and they have been documented to represent a highly diverse assemblage of species and genera (Bratishko et al. 2015; Schwarzhans et al. 2015). Moreover, Sarmatian gobiid otoliths collected by Weiler and Strashimirov and housed in the collections of the Senckenberg Museum, Frankfurt/Main (SMF) and the Museum of Geology and Paleontology, University of Mining and Geology "St. Ivan Rilski", Sofia (UMG), respectively, provide additional information to such a complex scenario. Therefore, we have included new otolithbased gobiid findings herein, with the scope to provide a comprehensive review, and to make use of both the skeletaland otolith-based data sets for an integrated evolutionary and paleogeographic evaluation.

With the new material described here from the collections assembled by Weiler and Strashimirov, the total number of verified otolith-based gobiid species from the late Badenian and Sarmatian reaches 15 species. Additional material currently being studied by Bratishko and Schwarzhans from the Sarmatian of the Crimea will further increase the taxonomic diversity. This amazing diversity compares to the nine skeleton-based gobiid species recognized from the same area and time interval. In fact, 12 of these otolith-based species occur in the Central and western part of the Eastern Paratethys, an area, where skeletonbased data have almost exclusively been assigned to Gobius pullus. Our review, however, reveals that the material that was assigned to Gobius pullus actually comprises five different species allocated to five different genera.

Here, we describe three new skeleton-based gobiid species with otoliths in situ, two of which are also known based on isolated otoliths, and one species is found to correlate with an already known otolith-based species. The systematic 
part is enriched by the description of five new otolith-based species. Most of the gobiids reported herein document the earliest phases of the evolutionary history of the endemic Ponto-Caspian lineages. We recognized articulated skeletons belonging to the genus Aphia, to a fossil genus related to Neogobius and Ponticola, Economidichthys, and two extinct genera related to Benthophilus and to the sand gobies. A very similar assemblage can be recognized based on otoliths, which document species of the genera Knipowitschia, Pomatoschistus, Benthophilus and Proterorhinus.

\section{Material and methods}

Eight articulated gobiid skeletons from the collection of the Croatian Natural History Museum, Zagreb (CNHM) were studied, four of which were found to contain otoliths in situ plus another with otolith impression only. A single specimen with otoliths in situ was found in the collection of the Chair of Historical Geology, Department of Regional Geology, Faculty of Mining and Geology, University of Belgrade (RGF), indicated with the collection acronym AJ (referring to the collection of Jelena Anđelković). All the Croatian specimens were originally identified as Gobius pullus by Kramberger (1882), whereas the Serbian one was referred to as Callionymus macrocephalus by Anđelković (1969). The holotype of Gobius pullus, herein assigned to Proneogobius n. gen. pullus, was studied during a visit at the CNHM.

All the skeletal materials with otoliths in situ housed at the CNHM were collected from the Sarmatian s.s. (Volhynian) deposits cropping out near Dolje, north of Zagreb. They are preserved in a finely laminated diatomite. The bones of the individual specimens are relatively well preserved, even if preparation is extremely difficult due to the brittle nature of the matrix. The delicate otoliths are difficult to extract from the matrix due to their weak mineralization. As a consequence, the otoliths were left in their in situ position as much as possible, particularly when their inner surface is exposed, and were carefully extracted only when necessary. The RGF specimen with otoliths in situ was collected from temporary excavations in 1961-1962 during the renovation of the Rajko Mitic football stadium (formerly 'Red Star') in Belgrade. This fish is embedded in a relatively hard gray mudstone and the preparation of the bones is very difficult. In contrast, otoliths are well preserved and were left in situ.

The studied otoliths originally collected by Weiler consist of 20 specimens from Austrian localities ranging from early to late Sarmatian s.s., plus 33 specimens from Romania, Czech Republic and Slovakia of undetermined Sarmatian age. The otoliths collected by Strashimirov ( 93 specimens, of which are 64 gobiids) are derived from 15 Bulgarian localities from sediments of Tarkhanian, late Badenian, and early to late Sarmatian s.l. age. The Weiler material is housed at the Senckenberg Museum, Frankfurt/ Main, Germany (SMF), whereas the material collected by Strashimirov is housed in the Museum of Geology and Paleontology, University of Mining and Geology "St. Ivan Rilski”, Sofia, Bulgaria (UMG).

A slightly modified version of the dorsal pterygiophore formula following Birdsong et al. (1988) is used herein. The initial digit indicates the interneural space into which the pterygiophore of the first dorsal fin inserts. A dash separates the sequence of interneural spaces starting with that into which the first pterygiophore inserts, and the number is the

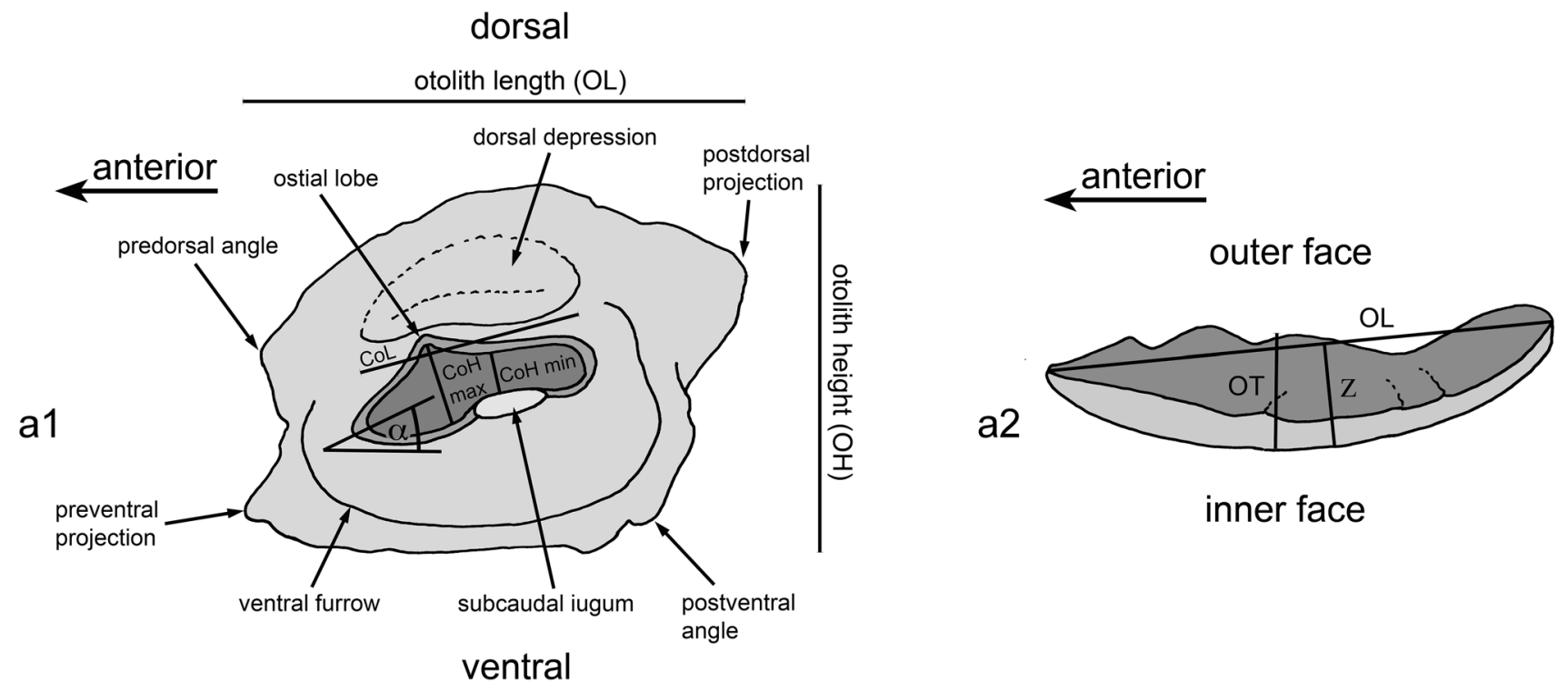

Fig. 1 Gobiid otolith terminology after Schwarzhans (2014); a1 inner face; a2 view from dorsal 
number of pterygiophores inserting at that position. An asterisk $(*)$ denotes a free pterygiophore. Zeros $(0)$ indicate interneural spaces without pterygiophores, usually located between the first and the second dorsal fin. The formula ends with the neural space and the associated first pterygiophore of the second dorsal fin. The morphological terminology of otoliths was established by Koken (1891) and subsequently modified by Weiler (1942) and Schwarzhans (1978); a more specific terminology for gobiid otolith morphologies was provided by Schwarzhans (2014) (Fig. 1).

Abbreviations general: $\mathrm{nm}=$ not measurable, $\mathrm{nv}=\mathrm{not}$ visible, $\quad$ vs $=$ versus, $\mathrm{HT}=$ holotype, $\mathrm{LT}=$ lectotype, $\mathrm{PT}=$ paratype(s); skeletons: $\mathrm{A}=$ anal fin rays, $\mathrm{AP}=$ anal pterygiophores prior to first haemal spine, $\mathrm{ART}=$ articular, $\mathrm{C}=$ principal caudal fin rays, $\mathrm{CH}=$ ceratohyal, $\mathrm{CL}=$ cleithrum, $\mathrm{COR}=$ coracoid, $\mathrm{CV}=$ caudal vertebrae, $\mathrm{D}=$ dentary, $\mathrm{D} 1=$ rays in first dorsal fin, $\mathrm{D} 2=$ rays in second dorsal fin, $\mathrm{EPT}=$ ectopterygoid, $\mathrm{EPU}=$ epural, $\mathrm{HL}=$ head length, $\mathrm{LAC}=$ lacrimale, $\mathrm{MX}=$ maxillary, $\mathrm{NS}=$ neural spine, $\mathrm{OP}=$ opercle, $\mathrm{P}=$ pectoral-fin rays, $\mathrm{PAL}=$ palatine, $\mathrm{PMX}=$ postmaxillary, $\mathrm{PT}=$ pterygiophore, $\mathrm{PTT}=$ posttemporal, $\mathrm{PV}=$ precaudal vertebrae, $\mathrm{QU}=$ quadratum, $\mathrm{SCL}=$ supracleithrum, $\mathrm{SL}=$ standard length, $\quad \mathrm{SOP}=$ subopercle, $\quad \mathrm{SYM}=$ symplectrum, $\mathrm{TL}=$ total length, $\mathrm{UH}=$ urohyal, $\mathrm{V}=$ pelvic-fin rays,
Fig. 3 Schematic location map of the Dacic Basin during Sarmatian s.s. depicting otolith sample localities in Bulgaria and Romania, and stratigraphic correlation chart showing samples from outcrops and sample intervals in wells (shaded). Those having yielded gobiid otoliths are shown in bold. Paleogeography after Popov et al. (2004). Geographic names follow local spelling. Dark shaded areas on the map represent emergent terrain; light shaded areas represent terrain covered by the Paratethys Sea

Roman numbers indicate fin spines, Arabic numbers indicate branched soft rays; otoliths: $\alpha=$ sulcus inclination angle, $\mathrm{CoL}=$ length of colliculum, $\mathrm{CoH} \max / \mathrm{min}=$ maximal and minimal height of colliculum, $\mathrm{OH}=$ otolith height, $\mathrm{OL}=$ otolith length, OT = otolith thickness, $\mathrm{SuL}=$ sulcus length, $\mathrm{OH}=$ otolith height, $\mathrm{OL}=$ otolith length, $\mathrm{OT}=$ otolith thickness, $\mathrm{SuL}=$ sulcus length, $\mathrm{Z}=$ curvature index of inner face (as percentage of OL).

\section{Regional geology and localities}

\section{(Figures 2 and 3)}

The regional stratigraphic terminology of the Central Paratethys follows Kováč et al. (2007). The articulated fish skeletal remains were collected from the lower Sarmatian s.s. (Volhynian) deposits exposed at Dolje, Croatia (see

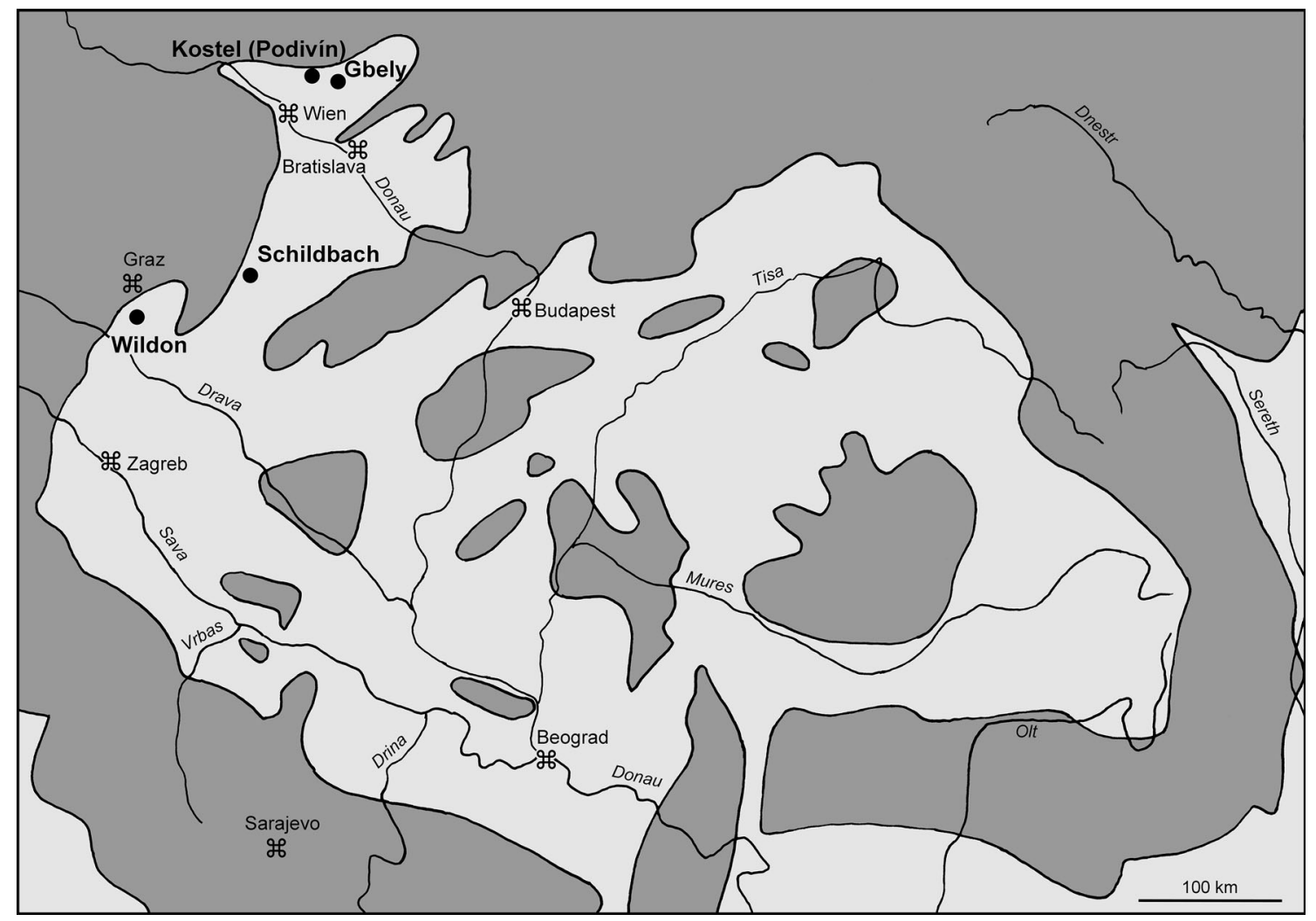

Fig. 2 Schematic location map of the Pannonian Basin during Sarmatian s.s. depicting otolith sample localities in Austria, Czech Republic and Slovakia. Paleogeography after Popov et al. (2004).
Geographic names follow local spelling. Dark shaded areas on the map represent emergent terrain; light shaded areas represent terrain covered by the Paratethys Sea 


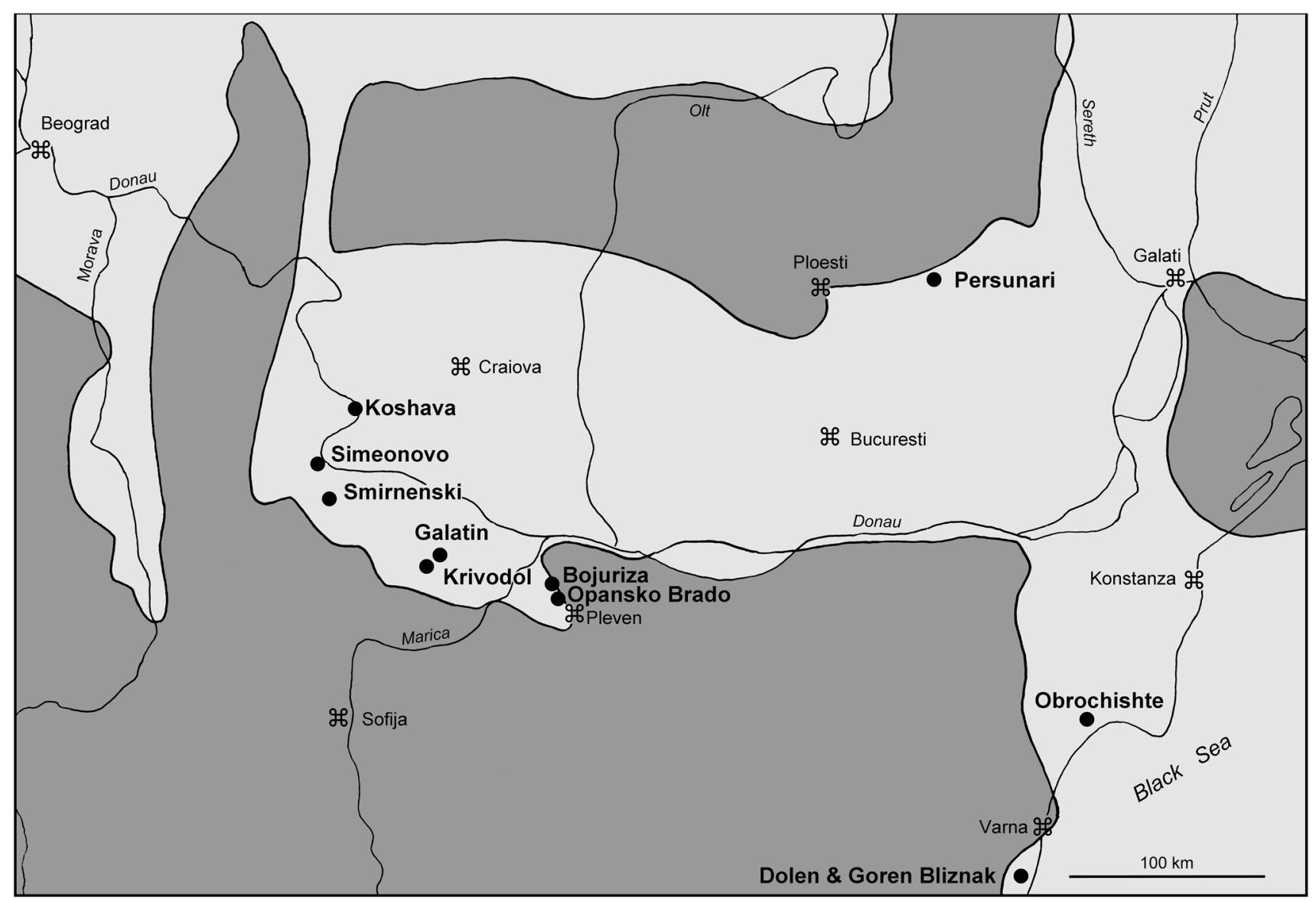

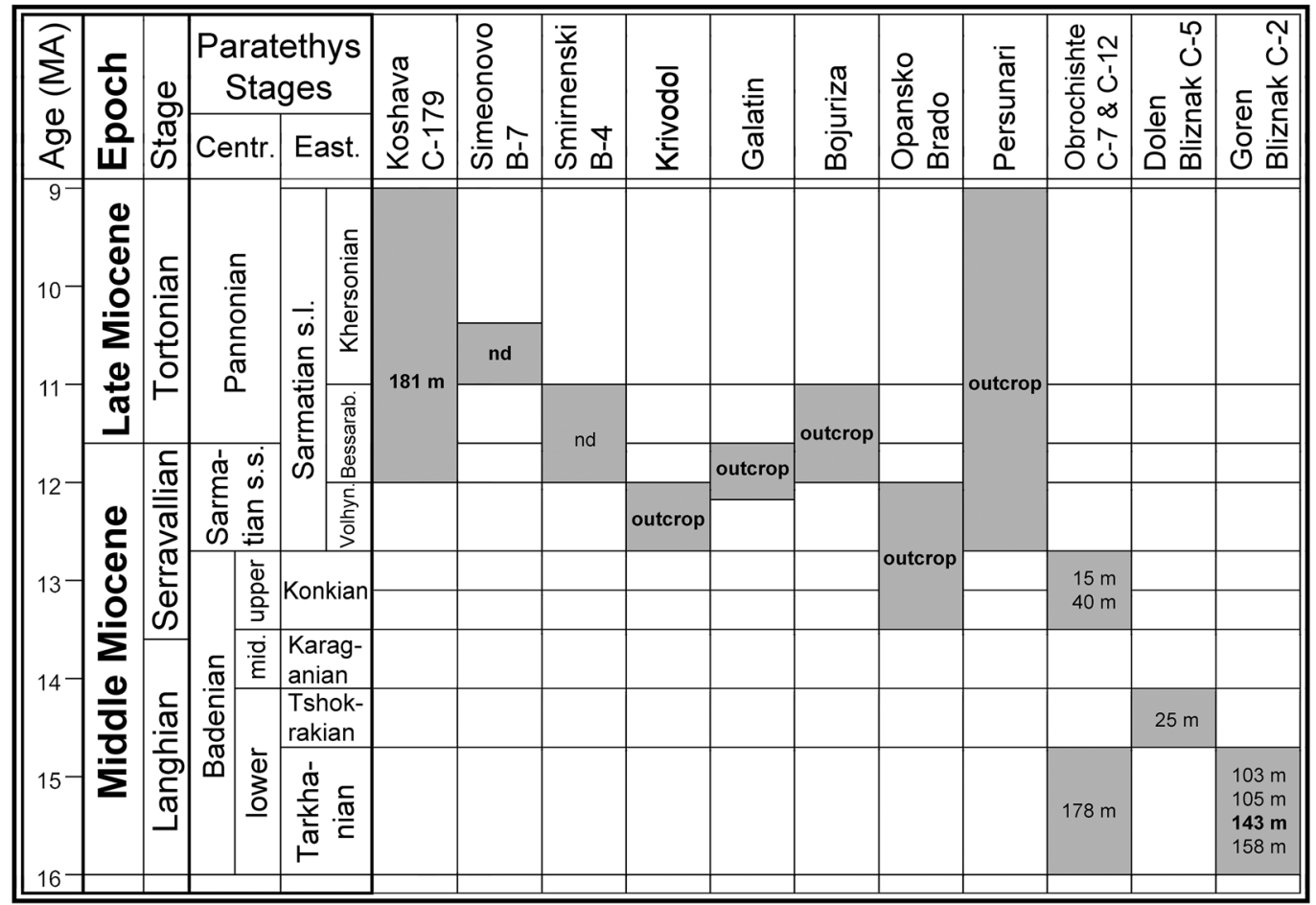


Vrsaljko et al. 2006 for details), and from approximately coeval strata in the subsurface of the Red Star stadium in Belgrade, Serbia (see Anđelković 1969 for details).

The isolated otoliths collected by Weiler and housed at SMF come from two localities of Sarmatian age in Romania and Slovakia, and from the early and late Sarmatian s.s. in Austria and Czech Republic. The Romanian locality is located near Persunari along the western rim of the Dacic Basin and has been annotated by Weiler as of late Sarmatian age (Fig. 3). However, we are not certain how this annotation would correspond to the Sarmatian s.s. of the Central Paratethys or the Sarmatian s.l. of the Eastern Paratethys and, therefore, consider the exact stratigraphic position of the samples as unresolved. The Slovakian locality refers to a shallow well near Gbely in the Vienna Basin (Fig. 2), annotated by Weiler as Gbely-358, with three samples at 14.5-15.5, 20.8-21.9 and 101.7-102.7 $\mathrm{m}$. The Czech locality refers to a well-named Kostel-1 (an old German name of the Czech city Podivín), 398.6-405.6 m, labeled as late Sarmatian. The Austrian sites refer to two localities collected by Kollmann in 1954 in the Styrian Basin, one near Wildon (early Sarmatian s.s.) and the other at Schildbach near Hartberg (late Sarmatian s.s.) (Fig. 2). The detailed geological description of the sedimentary sequence of the Hartberg region by Brandl (1931, 1953) confirms the likely late Sarmatian s.s. age annotated by Weiler and/or Kollmann, e.g., P. granosum zone according to Friebe (1994). Additional details for any of these localities are unknown.

The isolated otoliths of the Strashimirov collection primarily are derived from various wells in Bulgaria drilled during the 1980s, mostly located in the southwestern part of the Dacic Basin, but few along the coast near Varna or Tolbuhin. The exact locations of most wells cannot be retrieved with much detail and it is inferred that the names of the wells reflect towns and villages nearby. Based on the notes by the late Strashimirov and references from the publications of Kojumdgieva et al. (1982), Kojumdgieva and Popov (1988) and Koleva-Rekalova (2000), it was possible to restrict the position of the localities and place most of the samples within a stratigraphic context (Fig. 3). The samples vary greatly from early Badenian to late Sarmatian s.l. and are sorted in the following list by age:

Tarkhanian (early Badenian): Goren Bliznak C-2, 103-105, 105-107, 143-145, 158 m; Goren Bliznak C-55, $180 \mathrm{~m}$ (no gobiid otoliths). Both localities mentioned in Strashimirov (1972) near Varna.

Tshokrakian (early Badenian): Dolen Bliznak C-5, 25 m near Varna.
Unspecified Tarkhanian or Tshokrakian (early Badenian): well C-8 without further denomination, $46 \mathrm{~m}$; Obrochishte C-7, $40 \mathrm{~m}$ (no gobiid otoliths), $178 \mathrm{~m}$; Obrochishte $\mathrm{C}-12,15 \mathrm{~m}$ (no gobiid otoliths). Obrochishte is located near Tolbuhin and a stratigraphic section is figured in Strashimirov (1980).

Buglovian $($ Konkian $=$ late Badenian): Bukovez C-8, 260 m; Gabrovniza C-8 (no gobiid otoliths), 365, 370 m. Both are probably localities in the southwestern Dacic Basin, but could not be located.

Volhynian (early Sarmatian s.l.): Krivodol, Nakhod 1; Opansko Bardo (Opanec?). Both are localities in the southwestern Dacic Basin. An outcrop near Krivodol is the type locality of the Krivodol Formation, which encompasses early and middle Sarmatian s.l. (Kojumdgieva and Popov 1988). According to annotations by Strashimirov, the otoliths are from the early Sarmatian s.l.

Late Volhynian to early Bessarabian (middle Sarmatian s.1.): Galatin. An outcrop near Galatin is the type locality of the Galatin Formation, a local equivalent to the middle part of the Krivodol Formation, primarily encompassing the early Bessarabian but extending downwards slightly into the late Volhynian (Kojumdgieva and Popov 1988).

Bessarabian (middle Sarmatian s.l.): Bojuriza, Smirnenski B-4 (no gobiid otoliths) (nearby outcrop locality shown in Kojumdgieva and Popov 1988).

Early Chersonian (late Sarmatian s.1.): Simeonovo B-7 (nearby outcrop locality shown in Kojumdgieva and Popov 1988).

Middle or late Sarmatian s.l. unspecified: Koshava C-179, $181 \mathrm{~m}$.

\section{Systematic paleontology}

\section{Order Gobiiformes Günther 1880}

Family Gobiidae Cuvier 1816

The Gobiidae represent the largest living family of marine teleosts. Their relationships have been subject of several recent molecular phylogenetic studies (see Agoretta et al. 2013). We follow the classification proposed by Agorreta et al. (2013) but still use Gobiinae and Gobonellinae as subfamilies. With respect to individual lineages, however, we make exception for the usage of the Benthophilus lineage (Gobiinae; Benthophilinae sensu Iljin 1927) containing the neogobiins and tadpole gobies. The gobiid subfamily Benthophilinae was first erected by Iljin (1927) to accommodate all the endemic Ponto-Caspian gobies. The subfamily Benthophilinae apparently was not used much in subsequent ichthyological literature and the 
related groups were variously referred to as neogobiins and tadpole gobies until Neilson and Stepien (2009) resurrected the subfamily Benthophilinae and introduced three tribes: the Neogobiini, Benthophilini and Ponticolini. In Agorreta et al. (2013), the benthophilins represent a monophyletic clade deeply nested within the Gobius lineage. However, we consider this group of gobies as a well-defined lineage distinct from the Gobius lineage at least since Middle Miocene times about $15 \mathrm{Ma}$ and refer to it as the Benthophilus lineage herein.

Subfamily Gobiinae Cuvier 1816

Aphia lineage sensu Agorreta et al. 2013

Genus Aphia Risso 1827

Aphia macrophthalma Schwarzhans, Ahnelt, Carnevale and Japundžić n.sp.

(Figure 4a, d; Table 1)

?1962 Gobius tenuis Weiler 1943.-Paghida: pl., fig. 3

1969 Callionymus macrocephalus Kramberger 1882.Anđelković: pl. 1, fig. 6

1989 Callionymus macrocephalus Kramberger 1882.Anđelković: pl. 7, fig. 3

Holotype RGFAJ29, nearly complete articulated skeleton (Fig. 4a) with the right saccular otolith and both utricular otoliths in situ (Fig. 4d), and the left saccular otolith represented as impression of the outer face, $14.5 \mathrm{~mm} \mathrm{SL}$.

Type location and horizon Collected during the excavations for the renovation of the football stadium 'Red Star' in Belgrade, Serbia, 1961-1962; early Sarmatian s.s.

Etymology A combination of macros (Greek) = large and ophthalmos $($ Greek $)=$ eye, referring to the large orbital diameter characteristic for this fish.

Diagnosis Gobiid fish of small size; $28(11+17)$ vertebrae; first dorsal fin with six spines; second dorsal fin with a single spine plus ten rays; anal fin with a single spine plus ten rays; dorsal pterygiophore formula 3-21111001; orbit diameter $9 \% \mathrm{SL}$; OL:OH $=0.8$; otolith with high dorsal rim and without postdorsal process; sulcus with deepened ostium and large, triangular subcaudal iugum.

Description Counts and measurements are reported in Table 1.

Neurocranium The skull is remarkably compressed dorsoventrally and laterally expanded. The cranial bones are badly damaged, crushed and fragmented and their morphology is only partially recognizable. Many bones are displaced from their original position. Most of the basicranium and otic region are nearly completely covered by the otoliths of the right side. The orbits are clearly recognizable and very large (Fig. 4a).
Jaws Remains of the premaxilla and dentary bearing small conical teeth, arranged into a single row, can be recognized. The maxilla is elongate and expanded posteriorly.

Suspensorium and opercular series The bones of the suspensorium are inadequately preserved. Fragmented remains of the opercular bones can be recognized lateral to both saccular otoliths.

Hyoid bar and gill arches A couple of branchiostegal rays are exposed in the specimen.

Axial skeleton The vertebral column is well preserved allowing a clear separation into precaudal and caudal vertebrae. There are $28(11+17)$ vertebrae. The vertebrae are somewhat elongated giving the trunk of the fish an elongated appearance. The pectoral fin covers the ventral parts of most of the precaudal vertebrae. Therefore, the shape and position of parapophyses and ribs are not visible. The neural and haemal spines are narrow and elongated, of similar length and insert on the anterior end of each vertebral centrum except for those on the last caudal vertebrae (9th to 16 th caudal vertebra). The neural spine of the 9th caudal vertebra inserts in the middle, those of the 10th-16th vertebra on the posterior end. The neural and haemal spines of the 16th caudal vertebra (ultimate vertebra to the urostyle) are expanded.

Caudal skeleton Most elements are clearly distinguishable, including the parhypural, the ventral (fused hypurals $1+2$ ) and the dorsal (fused hypurals $3+4$ ) hypural plates, the latter fused to the urostyle. The hypural 5 is not preserved, even if it is recognizable as a feeble impression. A single fragmented epural is recognizable. There are 18 principal caudal rays.

Median fins There are two dorsal fins and a single anal fin. The first dorsal fin contains six spines, each supported by a single pterygiophore. It originates above the third abdominal vertebra and ends above the seventh abdominal vertebra. The second dorsal fin contains 11 fin elements (a single spine followed by ten dorsal-fin rays). It originates above the tenth abdominal vertebra (penultimate abdominal vertebra) ending above the 20th vertebra (tenth caudal vertebra). These fins are distinctly separated by a large interdorsal gap. The anal fin originates immediately behind the origin of the second dorsal fin, just below the 11th vertebra, ending at the level of the ninth caudal vertebra; it contains a single spine followed by ten fin rays. The first anal-fin pterygiophore is directly opposite to the second pterygiophore of the second dorsal fin.

Paired fins and girdles The pectoral- and pelvic-fin rays are partially preserved. The pectoral fin contains at least 12 rays. The rest of the fin skeleton and the elements of the pectoral and pelvic girdles are not clearly recognizable.

Otolith (sagitta) The otolith is small, high bodied and about $0.5 \mathrm{~mm}$ in length; $\mathrm{OL}: \mathrm{OH}$ is 0.8 . Its thickness is not 


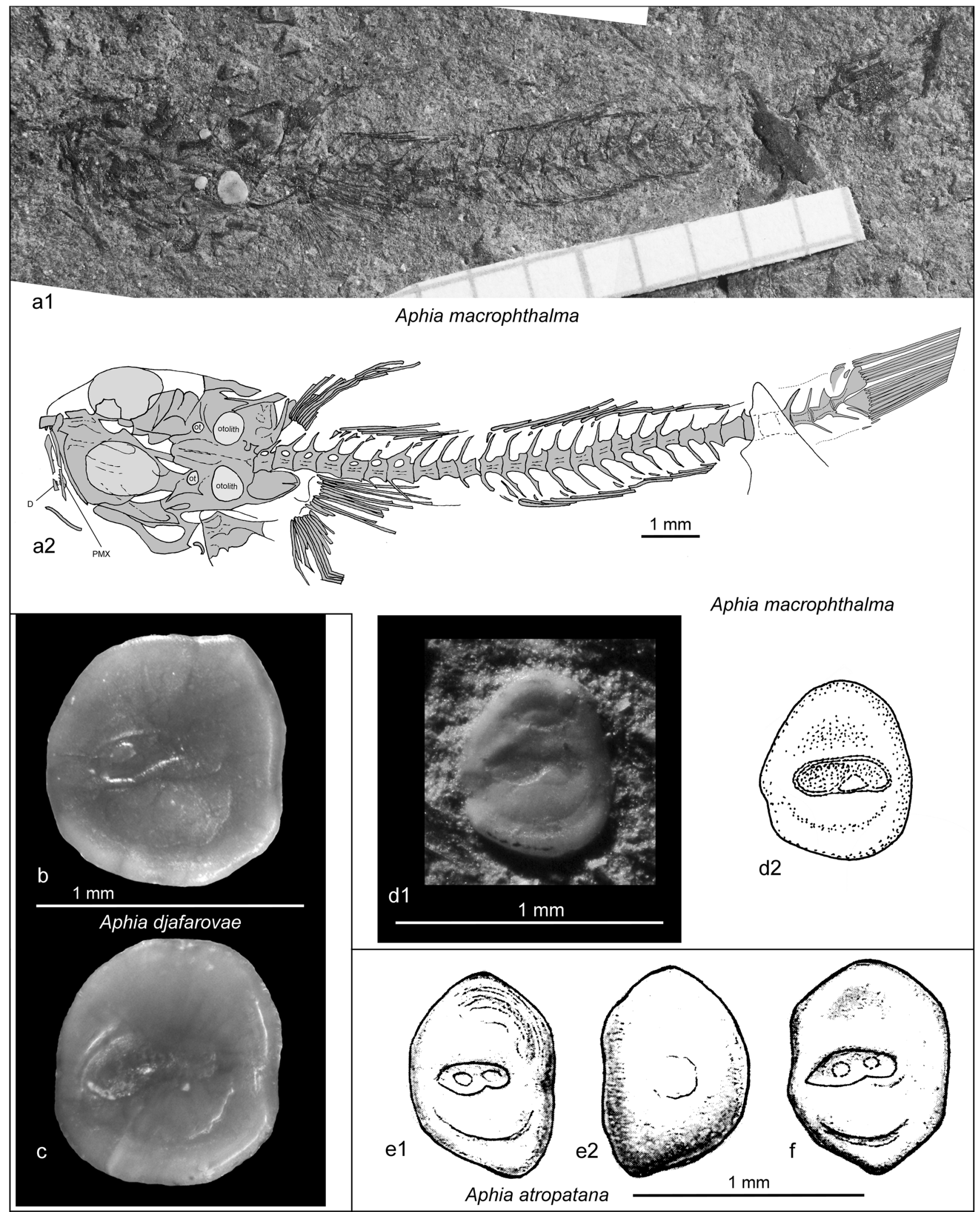


4Fig. 4 Skeleton and otoliths of Aphia. a articulated skeleton of Aphia macrophthalma n.sp. (mirror imaged), holotype, RGFAJ29, early Sarmatian s.s., Belgrade, Serbia, a1 photograph, a2 interpretative reconstruction; b, c otoliths of Aphia djafarovae Bratishko, Schwarzhans and Reichenbacher 2015 (refigured from Bratishko et al. 2015), Konkian, Mangyshlak, Kazakhstan; d otolith of Aphia macrophthalma n.sp. found in situ in RGFAJ29 (mirror imaged), d1 photograph, $\mathbf{d} 2$ drawing; $\mathbf{e}, \mathbf{f}$ otoliths of Aphia atropatana (Djafarova 2006) (refigured from Djafarova 2006) (e = mirror imaged), middle Sarmatian, Nakhitchevan, Azerbaijan

measurable (otolith embedded in rock). The dorsal rim is very high; the ventral rim is moderately deep and regularly curved. The anterior rim is bluntly rounded, with a broad, lower projection at the level of the sulcus and inclined backwards dorsally. The posterior rim is almost vertically cut, without a postdorsal lobe or projection. All rims are smooth.

The inner face is flat, even slightly concave in vertical direction. The sulcus is small, narrow, almost horizontal and not inclined, and positioned slightly inframedian. CoL:CoH $\max =3$; CoL:CoH min about 7.8. The ostium is about twice as long as the cauda, anteriorly rounded and with a very feeble ostial lobe. The cauda is small and set off from the ostium by a deeply incisive, triangular subcaudal iugum. The ostium is slightly deepened in comparison to the cauda. The dorsal field shows a broad, relatively short depression. The ventral field has a broad ventral furrow running at considerable distance from the ventral rim of the otolith. The outer face is mildly convex and smooth, judging from the imprint of the left otolith.

Discussion Aphia macrophthalma resembles the extant $A$. minuta in many meristic, morphometric, osteological and especially in otolith characters, including: (1) high bodied otolith without postdorsal projection, the ostium deepened compared to the cauda with a low ostial lobe and a strong, broad subcaudal iugum. (2) 28 vertebrae (vs mostly 27-28), of which 11 are abdominal (vs 10) and 17 are caudal (vs mostly 17-18) (Rojo 1985; Birdsong et al. 1988). The plesiomorphic state for extant Gobiidae is 10 abdominal vertebrae, although most of the North-eastern Atlantic and Mediterranean gobiids exhibit 11 elements (Miller 1981; Birdsong et al. 1988; Simonovic 1996; McKay and Miller 1997). The Aphia lineage is currently regarded as a sister group to the Valenciennea lineage (Thacker 2015). Aphia minuta has typically 27 vertebrae $(10+17)$ and differs in this trait from the species of the sister lineage Valenciennea by having an additional caudal vertebra (17 vs 16). Therefore, the presence of 11 abdominal vertebrae in A. macrophthalma may represent a derived condition resulting from the insertion of an extra vertebra between the eighth abdominal and first caudal vertebrae. As a result of this additional abdominal vertebra, two interneural spaces are present anterior to the first pterygiophore of the second dorsal fin in $A$. macrophthalma, while all the extant species of the Aphia and Gobius linages have only one free interneural space. (3) First dorsal fin with six spines vs primarily five elements (ranging from four to six) in A. minuta. The loss of a spine in the first dorsal fin in A. minuta possibly represents a derived character. Although the sixth spine is lost in the Recent species, the sixth pterygiophore is still developed (Rojo 1985). (4) Dorsal pterygiophore insertion pattern 3-21111001 vs mostly $3-1311 * 01$ to 3-221101 in A. minuta. Birdsong et al. (1988) mention a pattern of 3-131001 in A. minuta, thereby suggesting that two vacant interneural spaces are present anterior to the second dorsal fin like in A. macrophthalma. However, the sixth pterygiophore is cartilaginous and reduced in size in A. minuta (Rojo 1985) and, therefore, possibly not recognized in the radiographs on which Birdsong et al. (1988) based the majority of their results. The analyses of specimens available to one of us (HA) support Rojo's (1985) counts. (5) The presence of two anal-fin pterygiophores anterior to the first haemal spine. (6) The presence of a single row of very small premaxillary and dentary conical teeth. Only small fragments of both bones are preserved in A. macrophthalma. The premaxilla includes two fragments seen in dorsal view and, therefore, the single visible row of teeth may not be complete. Another very small bone fragment interpreted as part of the dentary shows a short row of four or five sockets. The extant A. minuta has a single row of small teeth on both premaxilla and dentary, which has been considered as an adaption to their suprademersal life by Mestermann and Zander (1984). (7) The impression of the leading edge of what appears to be a single epural. These conformities are our main arguments for placing the fossil specimen in the genus Aphia.

Aphia macrophthalma differs from A. minuta in having a large orbit (orbit diameter $9 \%$ SL vs $6.5 \%$ SL), low number of second dorsal-fin rays $(\mathrm{I}+10$ vs $\mathrm{I}+11-13)$ and anal fin rays $(\mathrm{I}+10$ vs $\mathrm{I}+13-14)$, a dorsal pterygiophore insertion pattern with two vacant interneural spaces anterior to the second dorsal fin vs one vacant interneural space, a sixth pterygiophore ossified vs cartilaginous and a very high otolith (OL:OH $=0.8$ vs 0.85-0.95).

Isolated otoliths of Aphia macrophthalma are not known. However, similar Aphia otoliths have been reported from the Konkian and the late Sarmatian s.l. of the Eastern Paratethys, namely A. djafarovae Bratishko, Schwarzhans and Reichenbacher 2015 and A. atropatana (Djafarova 2006), respectively. The earlier A. djafarovae (Fig. 4b, c) differs in having a wider ostium and a less high body shape $(\mathrm{OL}: \mathrm{OH}=0.9-1.0$ vs 0.8$)$. Similar otoliths probably representing the same species have been recorded as "genus Gobiidarum" sp. 3 from the late early Badenian and middle 
Table 1 Counts and measurements of Aphia macrophthalma n.sp. and comparison with the extant Aphia minuta (Risso, 1810) (extant data after Rojo 1985)

\begin{tabular}{|c|c|c|}
\hline & $\begin{array}{l}\text { Aphia macrophthalma n.sp. } \\
\text { HT-RGFAJ29 }\end{array}$ & Aphia minuta \\
\hline $\mathrm{SL}(\mathrm{mm})$ & 14.5 & $<58$ \\
\hline Otolith in situ & Yes & \\
\hline \multicolumn{3}{|l|}{ Meristics } \\
\hline Precaudal vertebrae & 11 & 10 \\
\hline Total vertebrae & 28 & $26-28$ \\
\hline D 1 & VI & V (IV-VI) \\
\hline D 2 & $\mathrm{I}+10$ & $\mathrm{I}+12(11-13)$ \\
\hline A & $\mathrm{I}+10$ & $\mathrm{I}+13-14$ \\
\hline Pectoral & $11+$ & $17-18$ \\
\hline D1 last ray between NS & NS7-NS8 & NS5-NS6 \\
\hline Empty neural spines & NS8-NS10 & NS7-NS9 \\
\hline D2 first PT between NS & NS10-NS11 & NS9-NS10 \\
\hline Caudal principle & 18 & $14-17$ \\
\hline Dorsal pterygiophore formula & 3-21111001 & $3-1311 * 01$ to $3-2211 * 01$ \\
\hline Anal PT1 opposite to & $\mathrm{D} 2 / 1$ & \\
\hline Postmaxillary process on PMX & nv & Present \\
\hline EPU & $1 ?$ & 1 \\
\hline AP & 2 & 2 \\
\hline SOP anterior-ventral shape & nv & Hook-like \\
\hline \multicolumn{3}{|l|}{ Scales } \\
\hline On head & nv & Naked \\
\hline On body & Few indications of scales & Predorsal naked \\
\hline Type & Cycloid? & Cycloid \\
\hline Scales along lateral line & $\mathrm{nm}$ & $19-25$ \\
\hline Scale size $(\mathrm{mm})$ & & \\
\hline \multicolumn{3}{|l|}{ Morphometrics (\% of SL) } \\
\hline Head length & 31.7 & $25-27$ \\
\hline Max. body height & 10.6 & $16-18.5$ \\
\hline Orbit diameter & 9.0 & $\sim 6.5$ \\
\hline D1 length & 10.0 & \\
\hline A length & 8.7 & \\
\hline $\mathrm{PL}=$ pectoral length & 17.0 & \\
\hline Predorsal to D1 & 36.0 & \\
\hline Predorsal to D2 & 54.3 & \\
\hline Preanal & 58.3 & \\
\hline Base of D1 & 10.3 & \\
\hline Base of D2 & 27.8 & \\
\hline Base of $\mathrm{A}$ & 22.8 & \\
\hline Distance of D1 to D2 & 8.0 & \\
\hline
\end{tabular}

Badenian of Poland by Radwanska (1992). Paghida (1962) described and figured an otolith from the late Badenian of Moldavia as Gobius tenuis Weiler 1943, which shows the deepened ostium which is typical for Aphia and a OL:OH ratio of 0.85 , which is closer to A. macrophthalma than $A$. djafarovae. We, therefore, tentatively refer this specimen with $A$. macrophthalma indicating that the two species $A$. macrophthalma and A. djafarovae actually may have occurred contemporaneously for some time. Aphia atropatana is even more high bodied than A. macrophthalma (OL:OH $=0.7-0.75$ ) based on Djafarova's drawings (Fig. 4e, f), and shows a very small sulcus and a conspicuous expansion of the postventral rim. These three species represent a discrete lineage within the genus endemic to the Paratethys, which became extinct sometimes during or after the late Sarmatian s.l. The otolithbased Aphia weinbrechti Schwarzhans 2010 represents a further species of the genus known from the Gramian/Late 
Tortonian of the North Sea Basin (equals Maeotian in the Eastern Paratethys). The otoliths of this species are somewhat less compressed (OL:OH $=0.85-0.95)$ and show no subcaudal iugum. The lack of the subcaudal iugum is also the main difference with the Recent $A$. minuta and thereby indicating that $A$. weinbrechti may not belong to the ancestral stock of the extant species.

Benthophilus lineage modified sensu Neilson and Stepien 2009

Genus Benthophilus Eichwald 1831

Benthophilus? ovisulcus Schwarzhans, Bradić and Bratishko n. sp.

(Figure 5a, b)

Holotype SMF P.2871c, an otolith from Persunari, Romania, Sarmatian s.l. (Fig. 5a).

Paratype SMF P.2871e, a single otolith from Persunari, Romania, Sarmatian s.1. (Fig. 5b).

Etymology Combination of ovum (Latin) = egg and the descriptive otolith term sulcus, referring to the very small, unstructured, oval, egg-shaped sulcus.

Diagnosis OL:OH $=0.9$. Ventral rim more deeply curved than dorsal rim. Inner face flat, outer face convex. Sulcus very small $(\mathrm{OL}: \mathrm{SuL}=2.6)$, compressed $\quad(\mathrm{CoL}$ :$\mathrm{CoH}=1.9-2.3)$ and unstructured oval in outline.

Description The otoliths are small, high bodied, reaching about $0.9 \mathrm{~mm}$ in length (holotype) and with a subquadrate outline. OH:OT $=2.9$. The dorsal rim is broad, slightly expanded anteriorly and posteriorly, without prominent angles. The ventral rim is deeply and very regularly curved without angles or projections. The anterior rim is nearly vertical, with rounded edges towards the dorsal and ventral rims. The posterior rim likewise is nearly vertical with rounded edges, but also with a small incision at about one-third from the top, above the caudal tip, resulting in a small, blunt postdorsal process above the incision. All rims are smooth.

The inner face is flat. The sulcus is extremely small, short, rather wide and oval to egg shaped with the caudal tip being narrower than the ostial tip. The sulcus is not or very slightly inclined, and positioned slightly supramedian. The ostium and cauda are not distinguishable from each other. There is no subcaudal iugum. The dorsal field is narrow, small, and with a rather distinct depression. The ventral field shows a wide, indistinct ventral furrow at about its midlength. The outer face is moderately convex, smooth.

Discussion Benthophilus? ovisulcus is readily recognized by its compressed subquadrate outline and the extremely small and not differentiated oval sulcus. It is more compressed and with a shorter sulcus than any of the known extant species of the genus and resembles Gobiusculus (see Nolf 2013), which lacks the incision of the posterior rim and also has a less reduced sulcus morphology and shows a subcaudal iugum (lacking in the Benthophilus lineage), except the fossil Gobiusculus rotundus (Pobedina 1954) (see below). It is possible that B.? ovisulcus represents an extinct, highly derived genus within the Benthophilus group, and, for this reason, we have tentatively assigned it to the genus Benthophilus.

Benthophilus styriacus Schwarzhans, Bradić and Bratishko n.sp.

(Figure 5c, d)

?1950 Gobius pretiosus Prochazka 1893.-Weiler: pl. 8, fig. 62 .

Holotype SMF PO 91749, an otolith from Schildbach near Hartberg, Styria, Austria, late Sarmatian s.s. (Fig. 5c).

Paratypes SMF P.2869, P.2872c, three otoliths from Persunari, Romania, Sarmatian (Fig. 5d).

Tentatively assigned specimens: SMF P.2848, a single poorly preserved otolith from Persunari, Romania, Sarmatian, figured by Weiler (1950).

Etymology Referring to the type locality in the Styrian Basin.

Diagnosis OL:OH = 1.10-1.15. Ventral rim flat; preventral and postdorsal projections short, broad, and rounded; predorsal and postventral angles broadly rounded. Inner face almost flat, outer face convex. Sulcus small $(\mathrm{OL}: \mathrm{SuL}=$ 2.0-2.2), narrow ( $\mathrm{CoL}: \mathrm{CoH}=2.7-3.0)$. Ostium and cauda nearly equally long and wide without ostial lobe and with small ventral indention. No subcaudal iugum.

Description The otoliths are small, moderately compressed, reaching up to about $1.5 \mathrm{~mm}$ in length (holotype $1.4 \mathrm{~mm}$ ) with a quadrangular outline. $\mathrm{OH}$ :OT $=2.5-2.7$. The dorsal rim is slightly anteriorly inclined with a depressed, rounded predorsal angle, and a broadly rounded postdorsal angle, followed by a blunt, short postdorsal projection. The ventral rim is straight, slightly concave at its middle section, and shows a slightly projecting, rounded preventral projection and a broadly rounded postventral angle. The anterior rim is nearly vertical to slightly inclined backwards towards dorsal and shows a weak indentation at about its midpoint. The posterior rim is slightly inclined backwards towards dorsal and shows a weak incision somewhat above its midpoint. All rims are smooth.

The inner face is almost flat with a slightly convex central part. The sulcus is small, relatively short, narrow, located at the middle of the inner face and inclined at about $15^{\circ}-18^{\circ}$. The dorsal margin of the sulcus is regularly curved without an ostial lobe, its anterior and posterior tips 


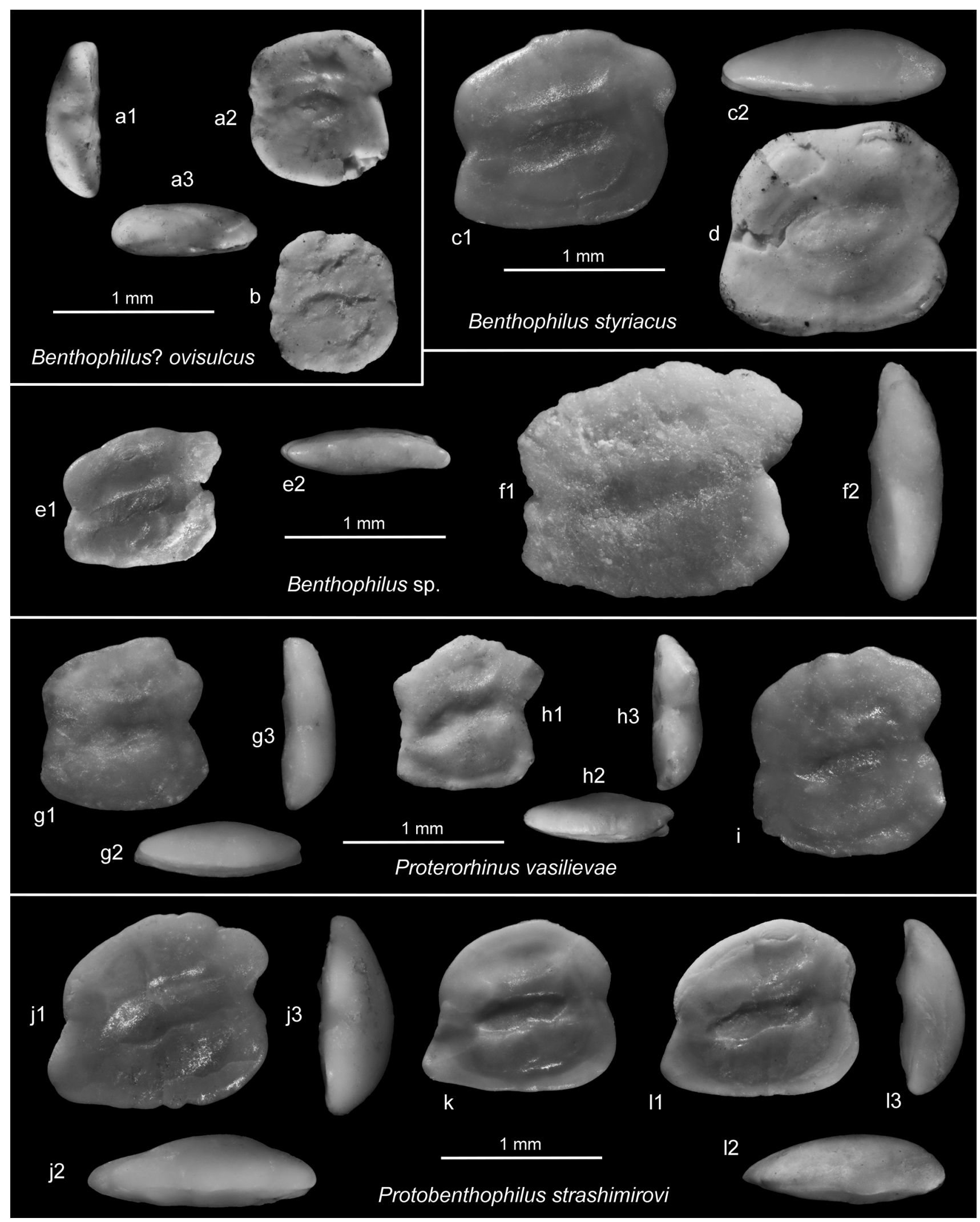


4Fig. 5 Otoliths of Benthophilus, Proterorhinus and Protobenthophilus n.gen. a, b Benthophilus? ovisulcus n.sp., a holotype, SMF P.2871c, Sarmatian s.1., Persunari, Romania, a1 anterior view, $\mathbf{a} 2$ inner face, $\mathbf{a} 3$ dorsal view, b paratype, SMF P.2871e, same data as holotype; c, d Benthophilus styriacus n.sp., c holotype, SMF PO 91749, late Sarmatian s.s., Schildbach near Hartberg, Austria, c1 inner face, c2 dorsal view, d paratype, SMF P.2872c, Sarmatian s.1., Persunari, Romania; e, f Benthophilus sp., e refigured specimen from Schwarzhans, Bradić and Rundić (2015), late Badenian, Barajevo-1 well, 65-70 m, Serbia, f SMF PO 91750, late Sarmatian s.s., Schildbach near Hartberg, Austria; g-i Proterorhinus vasilievae Schwarzhans, Bradić and Rundić 2015. g SMF PO 91754, late Sarmatian s.s., Schildbach near Hartberg, Austria, g1 inner face, g2 dorsal view, g3 posterior view, h SMF P.2872b, Sarmatian s.l., Persunari, Romania, h1 inner face, $\mathbf{h} \mathbf{2}$ dorsal view, $\mathbf{h} \mathbf{3}$ posterior view, i SMF PO 91753 (mirror imaged), late Sarmatian s.s., Schildbach near Hartberg, Austria, j-l Protobenthophilus strashimirovi n.gen. et sp., paratypes, UMG-X 8587, early Sarmatian s.l., Krivodol, Bulgaria, j1 inner face, $\mathbf{j} \mathbf{2}$ dorsal view, $\mathbf{j 3}$ posterior view, $\mathbf{k}$ holotype, UMG-X 8590, early Sarmatian s.1., Krivodol, Bulgaria, 11 inner face, $\mathbf{1 2}$ dorsal view, $\mathbf{1 3}$ posterior view

are regularly rounded and its ventral rim shows a small indentation at about its midpoint indicating a faint discrimination between ostium and cauda. There is no subcaudal iugum. The dorsal field shows a narrow, often indistinct dorsal depression. The ventral field shows a broad ventral furrow and the area between the ventral furrow and the sulcus is somewhat elevated. The outer face is moderately convex and smooth.

Discussion The characteristic pattern with a small sulcus with regularly curved dorsal margin without ostial lobe, the rounded anterior and posterior tips, and the small indentation at the ventral rim is characteristic of otoliths of Benthophilus, as are the rather flat inner face and weak postdorsal and preventral projections. The known otoliths of Recent species of this genus are all more elongate than those of $B$. styriacus. We consider $B$. styriacus as a typical representative of the genus, representing the earliest in record.

Benthophilus sp.

(Figure 5e, f)

2015 'Gobius' aff. pullus Kramberger 1882.-Schwarzhans, Bradić and Rundić: fig. 8.1

Material SMF PO 91750-51, two otoliths from Schildbach near Hartberg, Styria, Austria, late Sarmatian s.s. (Fig. 5f).

Description The two otoliths are moderately large and elongate, reaching up to about $1.8 \mathrm{~mm}$ in length. The outline is quadrangular. $\mathrm{OL}: \mathrm{OH}=1.15-1.2$; $\mathrm{OH}: \mathrm{OT}=3.0$. The dorsal rim is anteriorly depressed and shows a broadly rounded mediodorsal angle, a right predorsal angle, and a moderately strong postdorsal projection. The ventral rim is flat, very slightly curved, with a weak and angular preventral projection and a broadly rounded postventral angle. The anterior and posterior rims show slight indentations at the level of the sulcus. The rims are smooth or slightly ornamented.

The inner face is moderately convex, and the postdorsal projection is moderately bent outwards. The curvature index of the inner face is about $10 \%$ of OL. The sulcus is slightly supramedian, narrow, and its inclination is about $13^{\circ}-18^{\circ}$. There is no ostial lobe and no subcaudal iugum (or a very faint indication). The dorsal depression is indistinct. The ventral furrow is broad, but with indistinct margin. The outer face is smooth and almost flat.

Discussion This is one of the gobiid otolith morphologies described herein with a discernable outward bent postdorsal projection, the other one being Proneogobius pullus. However, the postdorsal projection is short and only slightly bent; the inner face is only moderately convex, a character shared with extant Benthophilus otoliths. The small sulcus with the flat, not expanded ostial lobe as well as the lack of a subcaudal iugum are also typical of Benthophilus. Most likely, these otoliths represent another undescribed species of Benthophilus; however, the specimens currently available are not suitable for a proper definition because of surface incrustations obliterating morphology (Fig. 5f), or the small size (Fig. 5e; refigured from Schwarzhans et al. 2015).

Genus †Proneogobius Schwarzhans, Ahnelt, Carnevale and Japundžić n.gen.

Type species: Gobius pullus Kramberger 1882.

Etymology A combination of pro (Latin) = before and the genus name Neogobius, referring to the basal relationship of the fossil genus to the extant genus Neogobius.

Diagnosis A genus of the family Gobiidae, subfamily Gobiinae, with the following combination of characters. 29-31 vertebrae, of which 11-13 abdominal; first dorsal fin with six to seven spines, second dorsal fin with a single spine plus nine to 12 rays; anal fin with a single spine plus ten to 12 rays; pectoral fin with 19 rays; last first dorsal-fin pterygiophore inserts between neural spines six and seven, vacant interneural space between neural spines seven and eight or nine, first pterygiophore of the second dorsal fin inserts between neural spines nine and ten or between neural spines ten and 11; dorsal pterygiophore formula 3222101 or 3-2221001; first anal-fin pterygiophore opposite to the third or fourth pterygiophore of the second dorsal fin; a single epural; two anal-fin pterygiophores in front of the first haemal spine. Body fully scaled; head naked except for few remnants on nape; scales ctenoid, probably 35-40 scales along lateral line. Head massive, large, 31.4-35.4\% of SL. Pectoral-fin length about $17-18 \%$ of SL. Otolith with quadrangular outline with short preventral and postdorsal projections, the latter only slightly bent outwards; 
sulcus with low ostial lobe and small, but distinct subcaudal iugum.

Discussion Proneogobius has a morphology intermediate between that of Gobius and Neogobius. For example, Gobius has 27-28 vertebrae, while in Neogobius, Ponticola and Proterorhinus the vertebral count ranges from 32 to 35 (down to 31 in Neogobius). Proneogobius has 29-31 vertebrae. The first one or two vertebrae are often covered by part of the opercle being difficult to observe in fossil material, providing an explanation why Kramberger (1882) noted only 28 vertebrae in his type specimen. The number of spines of the first dorsal fin (VI-VII) and dorsal pterygiophore formula (3-22210(0)1) resemble more Neogobius than Gobius, probably reflecting the incipient additions in the vertebrate column at the boundary between the precaudal and caudal vertebrae (11 precaudal vertebrae in Gobius, 11-13 precaudal vertebrae in Proneogobius, and 13-14 precaudal vertebrae in Neogobius). The second dorsal fin and the anal fin on the other hand show a reduced number of fin rays also found in Gobius rather than in Neogobius. Likewise the low number of scales along the lateral line is similar to that found in Gobius (30-65 vs 45-65 in Neogobius). The position of the anal fin, however, is more forward positioned than in any of the related extant genera (first analfin pterygiophore opposite to the third or fourth pterygiophore of the second dorsal fin vs opposite to the fifth in Gobius and the seventh or eighth in Neogobius).

The otoliths of the genera Gobius, Neogobius and Ponticola are difficult to distinguish from each other and there is not a single character or a combination of characters unequivocally distinguishing all three genera throughout the morphological continuum exhibited by all the species involved. However, otoliths of Ponticola are always more elongate than those of Neogobius and also Proneogobius, further supporting the existence of a closer relationship of the latter two. The outward bent of the postdorsal projection is rather weak in Neogobius and Proneogobius when compared to Ponticola and most of the Gobius species. The presence or absence and expression of the subcaudal iugum are usually a valuable character for species differentiation, but often show a mosaic distribution pattern within genera and hence rarely add value on higher taxonomic levels. For instance, otoliths of the species of the genus Gobius usually show a distinct, often wide subcaudal iugum (see figures in Lombarte et al. 2006), but in G. cobitis and G. paganellus it is absent. In Ponticola, a subcaudal iugum is usually present, but rather delicate and weak, even if there are a few species, in which it is absent ( $P$. constructor, $P$. cyrius, $P$. eurycephalus $P$. gymnotrachelus). Concerning the three extant species of Neogobius, the subcaudal iugum is absent in $N$. caspius and $N$. fluviatilis, while it is present in N. melanostomus (see figures in Jacobs and Hoedemakers, 2013).

While Proneogobius seems to represent a basal morphology in the neogobiin clade of the Benthophilus lineage, there is also evidence from otoliths that more advanced genera of the group discussed above were present at that time. Bratishko et al. (2015) described Neogobius udovichenkoi Bratishko, Schwarzhans and Reichenbacher 2015 and Ponticola zosimovichi Bratishko, Schwarzhans and Reichenbacher 2015 from the late Badenian of the Eastern Paratethys. Both species are characterized by a complete lack of a subcaudal iugum, which is consistent with certain extant species of both genera, while they are well distinguished from the only two Gobius species without subcaudal iugum, G. cobitis and G. paganellus, which have elongate otoliths with a strongly convex inner face and strongly concave outer face including the strongly bent postdorsal projection. Otoliths of Proterorhinus are more compressed than any of the genera discussed herein (OL:OH $=0.9-1.0$ vs $1.15-1.6)$.

Species A single species, Proneogobius pullus (Kramberger 1882) from the Middle Miocene, early Sarmatian s.s. of the Central Paratethys.

Proneogobius pullus (Kramberger 1882)

(Figures 6a-d, 7a-f; Table 2)

1882 Gobius pullus Kramberger.-Kramberger: pl. 25, fig. 2, ?2a

Material Four specimens from Dolje, Croatia, Sarmatian s.s. (Volhynian). CNHM 146, lectotype, (SL $35 \mathrm{~mm}$ ) (Fig. 6a), plus three referred specimens collected by Kramberger: CNHM 145 (SL $34 \mathrm{~mm}$ ) (Figs. 6c, 7d), CNHM 150 (SL $30+$ mm) (Figs. 6d, 7a, c, e, f), CNHM 151 (SL 33.5 mm) (Figs. 6b, 7b); Kramberger's paralectotype from Podsused was not studied and, therefore, is only tentatively included (Kramberger's Fig. 2a in plate 25); specimen CNHM 150 contains both saccular otoliths and the left utricular otolith in situ (Fig. 7f); the left sagitta is seen from the outer face, and the right sagitta from the inner face.

Diagnosis As for the genus.

Description Skeleton: Counts and measurements are reported in Table 2.

Neurocranium. The skull is laterally compressed in two of the four specimens and dorso-ventrally compressed in the other two specimens. Most cranial bones are badly damaged and fragmented and their morphology is only partially recognizable. The frontals form the largest part of the skull roof (Fig. 6a), separated by a very low crest, followed by a 


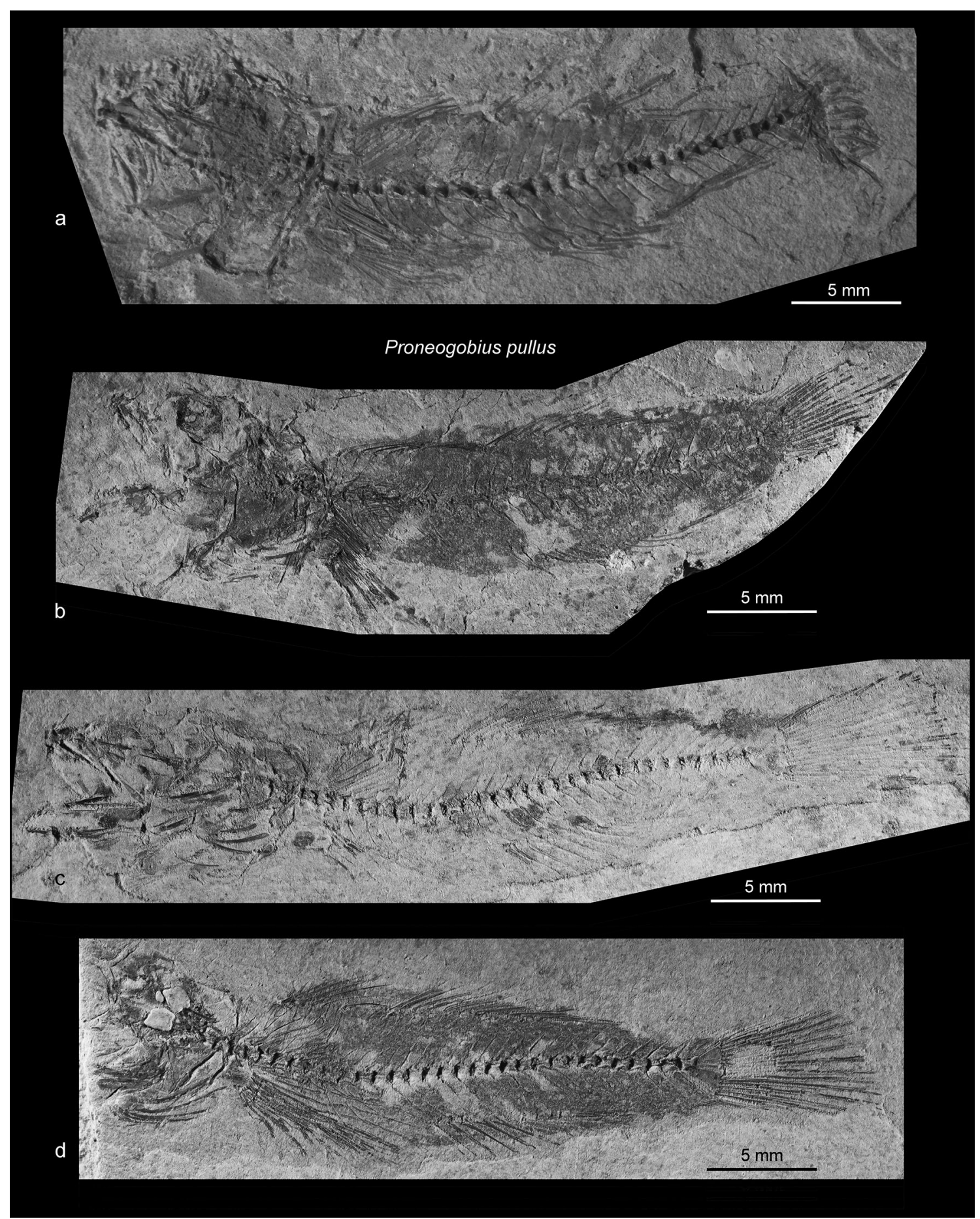

Fig. 6 Articulated skeletons of Proneogobius pullus (Kramberger 1882) n.gen., early Sarmatian s.s., Dolje, Croatia. a lectotype, CNHM 146 (mirror imaged), b CNHM 151 (mirror imaged), c CNHM 145 (mirror imaged), d CNHM 150

median supraoccipital indicated by a shallow longitudinal crest immediately anterior to the first vertebra. A groovelike depression which carries the interorbital section of the supraorbital canal is recognizable. The posterior part of the interorbital section and the postorbital sections of the supraorbital canal are clearly exposed in Fig. 6d as a laterally lying Y-shaped structure. The nasal is rod-like and characterized by a groove-like depression on its dorsal side, representing the origin of the supraorbital canal. The elongate sphenotic extends posterior to the orbit followed posteriorly by the larger and flat pterotic. The parasphenoid is straight and forms most of the basicranium. Anteriorly, it 

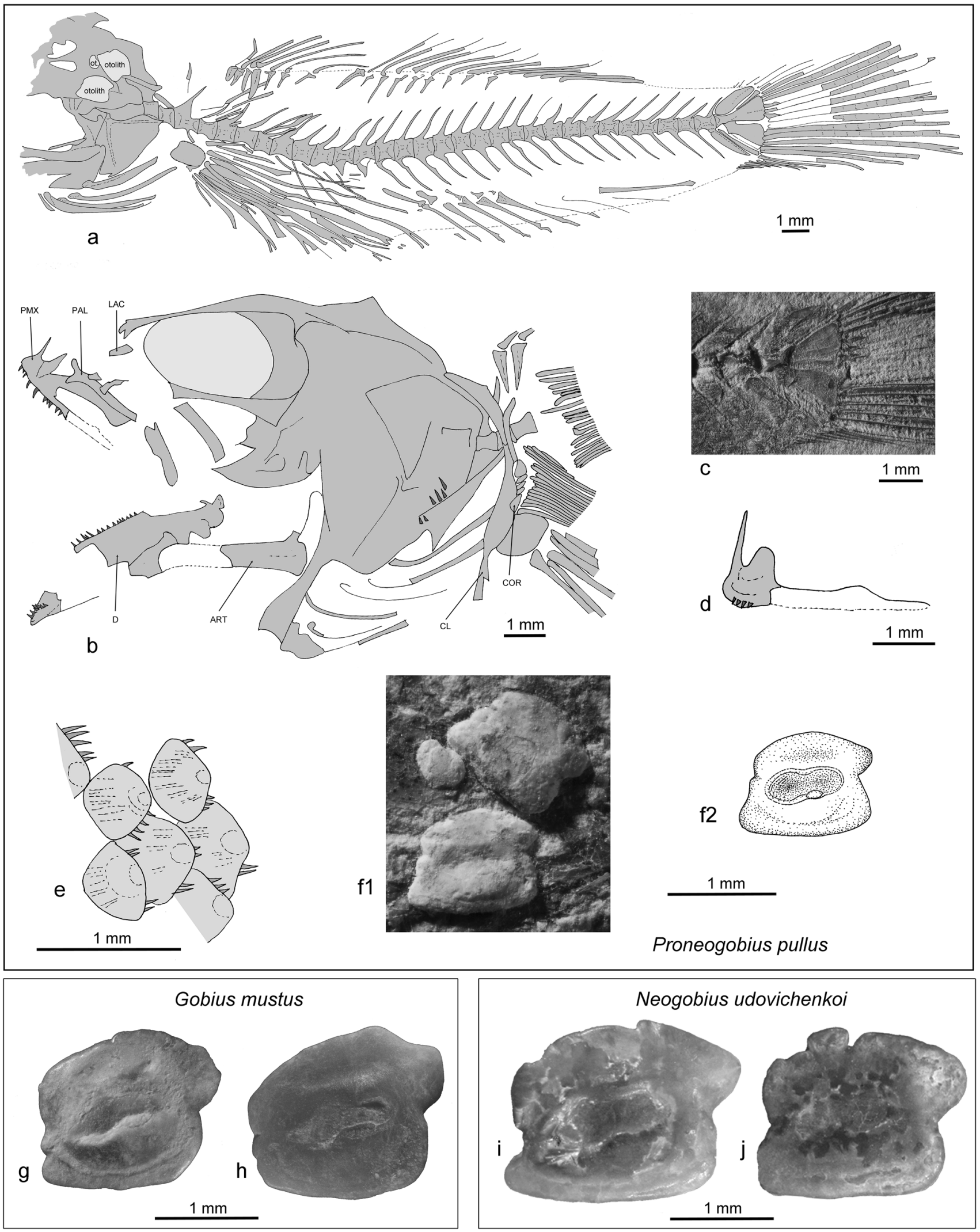
4Fig. 7 Skeleton and otoliths of Proneogobius n.gen., and otoliths of Gobius and Neogobius. a-f Proneogobius pullus (Kramberger 1882) n.gen., a CNHM 150, interpretative reconstruction of articulated skeleton, b CNHM 151 (mirror imaged), interpretative reconstruction of skull, c CNHM 150, detail of caudal skeleton, d CNHM 145 (mirror imaged), detail drawing of premaxillary, e CNHM 150, detail drawing of scale patch, f otolith found in situ in CNHM 150, f1 photograph, f2 drawing; g, h Gobius mustus Schwarzhans 2014, coll. Schwarzhans, Serravallian, Seythasan, southeastern Turkey; i, j Neogobius udovichenkoi Bratishko, Schwarzhans and Reichenbacher 2015 (refigured from Bratishko et al. 2015), Konkian, Mangyshlak, Kazakhstan Holotype, i holotype, NMNH 2532/075, j paratype, NMNH 2532/073

is overlapped by the vomer which is knob-like shaped at its anterior end (Fig. 6a-c).

Jaws The premaxilla bears a pointed ascending process, separated through a deep notch from the articular process (Fig. 7d); the postmaxillary process forms a shallow longitudinal crest (Fig. 7b). The alveolar process of the premaxilla bears conical teeth of different sizes (Figs. 6a-c, $7 b)$. The maxilla has an expanded or ovoid distal end (Fig. 6a-c). The dentary is deep and gradually increases in height posteriorly; its posterior edge is notched. The dentary teeth are similar to the premaxillary ones. The pointed anterior end of the anguloarticular fits into the posterior notch of the dentary. This bone is anteriorly also notched divided into a dorsal and ventral ramus. The articular surface between anguloarticular and retroarticular is not recognizable.

Opercular series The opercle is triangular (Figs. 6d, 7a). Anterior to the subopercle, it is clearly recognizable a long, blade-like and ovoid interopercle (Fig. 6c, d). The preopercle is narrow and crescent shaped (Fig. 6c).

Suspensorium The quadrate consists of a subtriangular bony lamina with a slightly curved process extending posterodorsally (Fig. 6a, c). The metapterygoid is small and does not articulate with the quadrate. The symplectic is long, with an expanded dorsal end. The suspensorial interspace (see Harrison 1989) is well developed. The ectopterygoid is elongate with an expanded posterior part. The palatine has a T-shaped appearance with two anterior processes; the maxillary process extends antero-laterally, whereas the ethmoid process extends medio-dorsally (Fig. 7b).

Hyoid bar and gill arches The hyoid bar, urohyal and sabre-like branchiostegal rays can be easily recognized, as well as the two contralateral pharyngobranchials. The latters bear conical teeth.

Axial skeleton The vertebral column consists of 29-31 vertebrae, of which 11-13 are abdominal. The neural and haemal spines are narrow, elongated and of similar length and insert on the anterior end of each vertebral centra except for those on the posterior four to five caudal vertebrae. The morphology of the neural spine of the second preural vertebra is variable being long and slender (Fig. 6d) or, alternatively, somewhat shorter and broad (Fig. 6a). The haemal spine of the second preural vertebra is expanded. The abdominal vertebrae 3-8 (Fig. 6b, c) bear long pleural ribs. Epineural bones are also present (Fig. 6c).

Caudal skeleton Most of the caudal skeleton is clearly distinguishable; it consists of an autogenous parhypural, two large hypural plates (hypurals $1+2$ and hypurals $3+4$ ), and a small autogenous hypural 5 (Fig. 7b). The epural is elongate and large, with a thickened posterior margin. There are 15 principal caudal rays (Fig. 7c).

Median fins The first dorsal fin contains six spines, each supported by a single pterygiophore. It starts above the third abdominal vertebra ending at the level of the seventh vertebra. The second dorsal and anal fins are elongate containing a single spine and about ten to 12 fin rays each; the posterior ends of both these fins are depressed making it impossible to conclusively identify the exact number of rays. The second dorsal fin starts above the ninth vertebra. The anal fin originates well posterior to the origin of the second dorsal fin. There is a single vacant interneural space between the seventh and eighth vertebrae.

Paired fins and girdles Of the pectoral girdle only the cleithrum and the coracoid are recognizable (Fig. 6b). The cleithrum is long and crescent shaped. The coracoid is roughly triangular. The basipterygium pelvic is triangular in outline. Each pelvic fin has a single short spine plus five rays (Fig. $7 \mathrm{a})$.

Scales Small ctenoid scales cover the entire trunk up to the caudal-fin base (Figs. 6b, d, 7e).

Otolith (sagitta) Small otolith of $1.3 \mathrm{~mm}$ in length; $\mathrm{OL}: \mathrm{OH}=1.3$. The thickness is not measurable (otoliths embedded in rock). The outline is nearly rectangular with pre- and postventral and postdorsal projections all about equally long and only the predorsal angle less pronounced than other angles. The dorsal rim is moderately high, gently curving, highest at about its middle, with a rounded predorsal angle and moderately projecting at the slender postdorsal projection, which is slightly bent outwards; the ventral rim is nearly flat. The anterior rim is obliquely cut, straight, slightly undulating, with a sharp, moderately projecting preventral projection, and inclined backwards from the anterior-ventral corner at about $75^{\circ}-80^{\circ}$; the posterior rim with its broad postventral projection is positioned less inferior than the preventral projection; it shows a deep incision above the middle of the posterior rim at level of the caudal tip and a sharper, slightly outward bent 
Table 2 Counts and measurements of Proneogobius pullus (Kramberger 1882) and comparison with aggregated extant genera Gobius, Neogobius and Ponticola (extant data after Ahnelt et al. 2000; Miller 2003; Whitehead et al. 1986)

\begin{tabular}{|c|c|c|c|c|c|c|c|}
\hline & \multicolumn{4}{|c|}{ Proneogobius n.gen. pullus } & \multirow[t]{2}{*}{ Gobius spp. } & \multirow[t]{2}{*}{ Neogobius spp. } & \multirow[t]{2}{*}{ Ponticola spp. } \\
\hline & LT-CNHM 146 & CNHM 150 & CNHM 151 & CNHM 145 & & & \\
\hline SL (mm) & 35 & 29.7 & 33.3 & 33.8 & $<180(270)$ & $<220$ & $<250$ \\
\hline Otolith in situ & No & Yes & No & No & & & \\
\hline \multicolumn{8}{|l|}{ Meristics } \\
\hline $\begin{array}{l}\text { Precaudal } \\
\text { vertebrae }\end{array}$ & $11^{* *}$ & $12 * *$ & 12 or $13 * *$ & 12 & 11 & $13-14$ & $13-14$ \\
\hline Total vertebrae & $29 * *$ & $31 * *$ & $30 * *$ & 30 & $27-28$ & $31-34$ & $32-35$ \\
\hline D 1 & VI & VII & VII & $\mathrm{nv}$ & VI & VI (VI-VII) & VI (V-VII) \\
\hline D 2 & $I+9-10$ & $\mathrm{I}+11$ & $\mathrm{I}+10$ & $\begin{array}{c}I+11 \text { or } \\
12\end{array}$ & $I+11-16$ & $I+13-17$ & $I+15-20$ \\
\hline A & $\mathrm{I}+10-11$ & I + 9+ & $\mathrm{I}+12$ & $\mathrm{I}+11$ & $\mathrm{I}+10-14$ & $!+11-16$ & $I+11-16$ \\
\hline Pectoral & $12+$ & nv & 19 & $11-12+$ & $15-23$ & $16-20$ & $16-21$ \\
\hline $\begin{array}{l}\text { D1 last ray } \\
\text { between NS }\end{array}$ & NS6-NS7 & NS6-NS7 & NS6-NS7 & nv & NS6-NS7 & NS6-NS7 & NS6-NS7 \\
\hline $\begin{array}{l}\text { Empty neural } \\
\text { spines }\end{array}$ & NS7-NS8 & NS7-NS8 & NS7-NS9 & $\mathrm{nv}$ & NS7-NS8 & NS7-NS8 & NS7-NS8 \\
\hline $\begin{array}{l}\text { D2 first PT } \\
\text { between NS }\end{array}$ & NS8-NS9 & NS8-NS9 & NS9-NS10 & NS8-NS9 & NS8-NS9 & NS8-NS9 & NS8-NS9 \\
\hline Caudal principle & $14+$ & 15 & 15 & 15 & $16-18$ & $15-17$ & $14-16$ \\
\hline $\begin{array}{l}\text { Dorsal } \\
\text { pterygiophore } \\
\text { formula }\end{array}$ & $\mathrm{nv}$ & $3-222101$ & $3-2221001$ & nv & $3-22110$ & $3-22110$ & $3-22110$ \\
\hline $\begin{array}{l}\text { Anal PT1 } \\
\text { opposite to }\end{array}$ & $\mathrm{D} 2 / 2$ & $\mathrm{D} 2 / 3$ & $\mathrm{D} 2 / 2$ & $\mathrm{D} 2 / 3$ & $\mathrm{D} 2 / 4$ & D2/6 or 7 & $\mathrm{D} 2 / 6$ or 7 \\
\hline $\begin{array}{l}\text { Postmaxillary } \\
\text { process on } \\
\text { PMX }\end{array}$ & $\mathrm{nv}$ & nv & nv & Present & Present & Present & Present \\
\hline EPU & 1 & 1 & nv & nv & 1 & 1 & 1 \\
\hline AP & 2 & 2 & 3 & 2 & $1-3$ & $1-3$ & $1-3$ \\
\hline $\begin{array}{l}\text { SOP anterior- } \\
\text { ventral shape }\end{array}$ & $\mathrm{nv}$ & Hook-like & Hook-like & $\mathrm{nv}$ & Hook-like & Hook-like & Hook-like \\
\hline \multicolumn{8}{|l|}{ Scales } \\
\hline On head & & $\begin{array}{l}\text { Few } \\
\text { remnants } \\
\text { visible on } \\
\text { nape }\end{array}$ & $\begin{array}{l}\text { Few } \\
\text { remnants } \\
\text { visible } \\
\text { on nape }\end{array}$ & & $\begin{array}{l}\text { Scales on } \\
\text { nape, } \\
\text { occ. rear } \\
\text { cheek }\end{array}$ & $\begin{array}{l}\text { Partly scaled } \\
\text { on nape, } \\
\text { occ. upper } \\
\text { opercle }\end{array}$ & $\begin{array}{l}\text { Nape scaled } \\
\text { completely, } \\
\text { rarely only } \\
\text { rear }\end{array}$ \\
\hline On body & & Fully scaled & Fully scaled & & Fully scaled & Fully scaled & Fully scaled \\
\hline Type & & Ctenoid & Ctenoid & & Ctenoid & $\begin{array}{l}\text { Ctenoid, head } \\
\text { cycloid }\end{array}$ & $\begin{array}{l}\text { Ctenoid, head } \\
\text { cycloid }\end{array}$ \\
\hline $\begin{array}{l}\text { Scales along } \\
\text { lateral line }\end{array}$ & & $32+(+5 ?)$ & $30+$ & & $30-65$ & $45-65$ & $42-75$ \\
\hline Scale size $(\mathrm{mm})$ & & $\sim 0.6$ & $\mathrm{~nm}$ & & & & \\
\hline \multicolumn{8}{|c|}{ Morphometrics (\% of SL) } \\
\hline Head length & 31.4 & $\mathrm{~nm}$ & 33.2 & 35.4 & $25-30$ & $25-32$ & $30-39$ \\
\hline Max. body height & 18.7 & 21.4 & 17.3 & 15.1 & $19-21$ & $16-26$ & $17-30$ \\
\hline Orbit diameter & $\mathrm{nm}$ & $\mathrm{nm}$ & 6.8 & 6.4 & $8.5-10.5$ & $5.5-6$ & $5.5-6$ \\
\hline D1 length & 12.4 & 14.0 & 11.1 & $\mathrm{nv}$ & & & \\
\hline A length & 15.2 & 10.7 & 11.2 & 12.1 & & & \\
\hline $\begin{array}{l}\mathrm{PL}=\text { pectoral } \\
\text { length }\end{array}$ & 16.8 & $\mathrm{~nm}$ & $\sim 17.5$ & $\mathrm{~nm}$ & & & \\
\hline Predorsal to D1 & 37.4 & $\mathrm{~nm}$ & 32.7 & $\mathrm{~nm}$ & & $30-37$ & $34-41$ \\
\hline
\end{tabular}


Table 2 continued

\begin{tabular}{lllllll}
\hline & \multicolumn{2}{l}{ Proneogobius n.gen. pullus } & & Gobius spp. & Neogobius spp. & Ponticola spp. \\
\cline { 2 - 5 } & LT-CNHM 146 & CNHM 150 & CNHM 151 & CNHM 145 & \\
\hline Predorsal to D2 & 53.1 & $\mathrm{~nm}$ & 53.4 & 54.6 & $47-50$ \\
Preanal & 61.4 & $\mathrm{~nm}$ & 58.5 & 64.7 & $52-56$ \\
Base of D1 & 9.1 & 10.5 & 12.4 & $\mathrm{nv}$ & $9.5-11.5$ \\
Base of D2 & 26.4 & 26.9 & 22.7 & 26.5 & $33-37.5$ & $34-41$ \\
Base of A & 26.2 & 26.8 & 31.0 & $19.8(?)$ & $30-33.5$ & $23-33.5$ \\
Distance of D1 to & 5.5 & 5.8 & 8.0 & $\mathrm{~nm}$ & & \\
$\quad$ D2 & & & & & \\
\hline
\end{tabular}

** First vertebra obscured

postdorsal projection of about equal length with a postventral projection resulting in a nearly vertical configuration of the posterior rim. All rims are smooth except few undulations on the anterior rim and a deep incision on the posterior rim.

The inner face is slightly convex. The sulcus is moderately wide, inclined at about $10^{\circ}$ and positioned slightly supramedian. $\mathrm{CoL}: \mathrm{CoH} \max =2.6$; $\mathrm{CoL}: \mathrm{CoH} \min =4.5$. The ostium is about as long as the cauda and only slightly wider, anteriorly rounded, with a very feeble ostial lobe. The small but well-marked subcaudal iugum underlies the anterior part of the cauda. The sulcus is considerably deepened. The dorsal field shows an indistinct, small depression; the ventral field shows a distinct ventral furrow running at moderate distance from the ventral rim of the otolith. The area between the rear part of the ventral furrow and the cauda is bulbous. The outer face is mildly convex and smooth.

Discussion Proneogobius pullus was originally described by Kramberger (1882) as Gobius pullus based on two specimens. Subsequently, seven specimens from Dolje were also assigned by him to this taxon. A review of all the eight specimens from Dolje revealed that four of them represent Proneogobius pullus, while the other four specimens belong to three different additional species in three different genera. In any case, $P$. pullus represents the most common gobiid species at Dolje; however, it is not clear, if and how many of the other specimens recorded as Gobius pullus from Podsused (Kramberger 1882) and Belgrade (Anđelković 1969) actually belong to this species.

There are no isolated otoliths recorded so far that could be assigned to Proneogobius pullus. A small otolith of about $0.9 \mathrm{~mm}$ in length recorded as 'Gobius' aff. pullus by Schwarzhans et al. (2015) from the late Badenian of Serbia differs in the absence of a subcaudal iugum and a depressed ostial lobe. The correlation was based on a photograph made prior to cleaning the surface of the otolith of CNHM 150. It is now considered to represent an undetermined species of Benthophilus (see above). Proneogobius pullus resembles two other coeval species: Gobius mustus Schwarzhans 2014 (Fig. 7g, h) from the Serravallian of SETurkey (Schwarzhans 2014) and Neogobius udovichenkoi (Fig. 7i, j) from the late Badenian (Konkian) of Kazakhstan (Bratishko et al. 2015). It differs from G. mustus in having a more slender postdorsal projection which does not extend beyond the postventral projection, a distinct postventral projection (vs broadly rounded), the highest point of the dorsal rim at its midlength (vs distinctly posterior of the middle), and a shallow ostial lobe (vs expanded and angular). Proneogobius pullus differs from Neogobius udovichenkoi in the presence of a subcaudal iugum and a less massive and shorter postdorsal projection. It also does not have such an anteriorly expanded and irregularly crenulated anterior part of the dorsal rim, which is characteristic for N. udovichenkoi.

In conclusion, there is no confirmed record of Proneogobius pullus outside of Dolje.

Genus Proterorhinus Smitt 1899

Proterorhinus vasilievae Schwarzhans, Bradić and Rundić 2015

(Figure $5 \mathrm{~g}-\mathrm{i}$ )

1962 Gobius praetiosus Prochazka 1893._Paghida: pl. 2, fig. 2

2008 Gobiidarum sp. 1.-Chalupova: fig. 4

2008 Gobiidarum sp. 2.-Chalupova: fig. 5

2015 Proterorhinus vasilievae Schwarzhans, Bradić and Rundić.-Schwarzhans, Bradić and Rundić: figs. 8.2-8.5.

Material Seven otoliths; SMF P.2836, P.2871a, P.2872b, PO 91752, five otoliths from Persunari, Romania, 
Sarmatian; (Fig. 5h) SMF PO 91753-54, two otoliths from Schildbach near Hartberg, Styria, Austria, late Sarmatian s.s. (Fig. 5g, i).

Discussion Otoliths of Proterorhinus vasilievae are characterized by a compressed shape (OL:OH $=0.9-0.95)$; sharp and equally pronounced predorsal and preventral angles; distinct postdorsal angle followed by a short postdorsal projection, which is only slightly bent outwards; and a distinctly sole-shaped sulcus with a long, rather narrow subcaudal iugum. It was originally described from the late Badenian of Serbia. The new records from the Sarmatian of Romania reveal a wider geographic and stratigraphic range.

Genus †Protobenthophilus Schwarzhans, Ahnelt, Carnevale and Japundžić n.gen.

Type species: Protobenthophilus squamatus Schwarzhans, Ahnelt, Carnevale and Japundžić n.sp.

Etymology A combination of protos (Greek) = first and the genus name Benthophilus, referring to the assumed ancestral position of the fossil genus with respect to the extant genus Benthophilus.

Diagnosis A genus of the family Gobiidae, subfamily Gobiinae exhibiting the following combination of characters; 28 vertebrae, of which 10 are abdominal; first dorsal fin with five spines, second dorsal fin and anal fin contain a single spine followed by eight rays; last first dorsal-fin pterygiophore inserts between neural spines five and six; vacant interneural space between neural spines six to eight; first pterygiophore of the second dorsal fin inserts between neural spines eight and nine; dorsal pterygiophore formula 3-221001; no free pterygiophores; first anal-fin pterygiophore opposite of the third pterygiophore of second dorsal fin; a single epural; two anal pterygiophores in front of first haemal spine; body scaled on trunk; predorsal region and head naked; scales ctenoid, approximately 27 scales along lateral line; head massive, large, measuring about $32 \%$ of SL; first dorsal-fin base narrow $(6.8 \%$ of SL); gap between first and second dorsal fin equals $9 \%$ of SL; pectoral-fin length about $13 \%$ of SL; anterior end of the subopercle without hook; otolith with sharply pointed and distinctly projecting preventral tip; postdorsal projection absent or weak; sulcus short, nearly uniformly oval in shape with poorly distinguished ostium and cauda and with low ostial lobe; no subcaudal iugum.

Discussion The Benthophilus group comprises four genera, Anatirostrum, Benthophiloides, Benthophilus and Caspiosoma (Miller 2004; Neilson and Stepien 2009), representing a morphologically distinct assemblage clearly separated from the other genera of the Gobius lineage sensu Thacker (2015). Protobenthophilus shares with the genera Benthophilus and Anatirostrum several characters, including: anterior end of subopercle without hook; first dorsal-fin base narrow $(6.8 \% \mathrm{SL})$, shorter than the gap between first and second dorsal fin (9\% SL); low number of precaudal vertebrae (10); low second dorsal- and analfin counts $(\mathrm{I}+8)$; and the otolith pattern without postdorsal projection and a short, poorly structured sulcus without subcaudal iugum. All these characters are considered synapomorphies of Benthophilus and Anatirostrum that distinguish them from the entire Gobius lineage including the neogobiin genera, e.g., Neogobius, Ponticola or Proterorhinus. Protobenthophilus differs from Benthophilus and Anatirostrum in the absence of free dorsal pterygiophores, dorsal pterygiophore formula 3-221001 vs $3-221 * 01 *$ or $3-211 * 1 * 01 *$, the presence of two vs one vacant interneural spaces, first interneural space located between neural spines seven and eight vs between neural spines six and seven, first anal-fin pterygiophore opposite to the second ray of the second dorsal fin vs the first pterygiophore of the second dorsal fin, and a slightly higher number of first dorsal-fin spines (five vs two to four). In Protobenthophilus (and all other genera of the Gobius lineage including Benthophiloides and Caspiosoma), the second dorsal fin extends anteriorly beyond the anal-fin origin, whereas in Anatirostrum and in Benthophilus the origin of the anal fin is positioned just under the origin of the second dorsal fin. In Protobenthophilus, the first pterygiophores of the second dorsal fin support a single spine and a single ray, respectively, vs the first two pterygiophores support no spine or rays $(01 * 1 *)$. This unique position of both fins is caused by a caudad shift of the spine and rays of the second dorsal fin. In Anatirostrum and Benthophilus, the first two pterygiophores of the second dorsal fin do not support a spine or ray (Ahnelt 2003). The loss of two to three spines in the posterior part of the first dorsal fin and the caudal shift of the second dorsal fin results in a very distinct gap between the two dorsal fins. This character (gap between the two dorsal fins) in Protobenthophilus is intermediate between Anatirostrum, Benthophilus and the other extant genera of the Gobius lineage. Protobenthophilus differs from Benthophiloides and Caspiosoma in having a first dorsal-fin base shorter vs longer than the gap between first and second dorsal fins, five vs six (=plesiomorphic number of fin spines for the Gobius lineage) dorsal-fin spines; Protobenthophilus further differs from Caspiosoma by having a subopercle without hook (vs with hook). The shape of the subopercle of Benthophiloides is unknown. Recent molecular biological studies revealed Caspiosoma linage as sister lineage to the Benthophilus lineage sensu stricto (Neilson and Stepien 2009; Medvedev et al. 2013).

Protobenthophilus also differs from Benthophilus and Anatirostrum in the lack of the dorso-ventrally compressed, 
broad-headed 'tadpole'-shape and hence probably was adapted to a more benthopelagic way of life like Caspiosoma. It differs from all extant genera of the Benthophilus group for the presence of unmodified ctenoid scales on the trunk. While Caspiosoma is naked, Benthophiloides may be naked or covered by non-imbricate ctenoid scales. These scales show very long ctenii (Iljin 1930) and are regarded as a possible precursor of the highly modified scales (spiny tubercles and granules) of Anatirostrum and the advanced species of Benthophilus (Miller 2004). The scales in the ancestral group of Benthophilus still resemble less modified ctenoid scales (Neseka and Bogutskaya 2009). Protobenthophilus can be regarded as a basal genus within the Benthophilus group, with its origin possibly predating the dichotomy of Benthophilus-Caspiosoma.

The otoliths of the genera of the Benthophilus group are characterized by a pattern reflecting certain morphological reductions, such as the short, nearly oval and poorly structured sulcus with a very low or absent ostial lobe, the absence of a subcaudal iugum (although this character shows a somewhat mosaic distribution; see above), and the reduction of the postdorsal projection. The latter character is more reduced (i.e., absent) in Protobenthophilus than in Benthophilus. So far, no fossil otoliths of representatives of the Benthophilus group have been described. Here, however, we record several otolith-based species of Protobenthophilus and Benthophilus, in parallel and are also aware of further, still undescribed otolith-based species of Benthophilus in the middle to late Sarmatian s.l. from the Crimea (Bratishko and Schwarzhans; unpublished material).

Species Two species from the Sarmatian s.l.: Protobenthophilus squamatus n.sp. based on a single articulated skeleton with otoliths in situ from the early Sarmatian s.s. of Dolje, Croatia and isolated otoliths of the same species found in various localities of early to late Sarmatian s.l. age in Bulgaria and Romania; Protobenthophilus strashimirovi n.sp. an otolith-based species from the early to middle Sarmatian s.l. of Bulgaria.

Protobenthophilus squamatus Schwarzhans, Ahnelt, Carnevale and Japundžić n.sp.

(Figure 8a-c, e-j; Table 3)

1943 Gobius vicinalis Koken 1891.-Weiler: pl. 1, fig. 29 (non fig. 30)

1949 Gobius vicinalis Koken 1891.-Weiler: pl. 4, fig. 29 (non fig. 30)

Holotype CNHM 272, an articulated skeleton measuring $19 \mathrm{~mm}$ SL with both saccular and utricular otoliths in situ, Dolje, Croatia, Sarmatian s.s. (Volhynian), Fig. 8a-c.

Referred material 18 isolated otoliths (Fig. 8e-j); SMF P.2871b, P.2872d, P.2873, P.2874, nine otoliths from
Persunari, Romania, unspecified Sarmatian; SMF PO 91748, four otoliths from Schildbach near Hartberg, Styria, Austria, late Sarmatian s.s.; UMG-X 8586, a single otolith from Krivodol, Bulgaria, Volhynian (early Sarmatian s.1.); UMG-X 8578, a single otolith from Galatin, Bulgaria, Volhynian to Bessarabian (early Sarmatian s.1.); UMG-X 8589, two otoliths from Bojuriza, Bulgaria, Bessarabian (middle Sarmatian s.1.); UMG-X 8584, a single otolith from Simeonovo B-7, Bulgaria, early Chersonian (late Sarmatian s.1.).

Etymology From squamatus (Latin) = scaly, referring to the scaly trunk of the fish.

Diagnosis See genus diagnosis for skeletal characters. Otoliths: OL:OH $=0.95-1.05$. Preventral projection sharp; no or only incipient postdorsal projection. Posterior rim vertical or inclined forward towards dorsal. Ostium with low ostial lobe; no subcaudal iugum. Sulcus inclination $8^{\circ}$ $10^{\circ}$.

Description Skeleton: Counts and measurements are reported in Table 3 .

Neurocranium The skull is large, massive and moderately compressed laterally. Its postorbital portion is badly damaged. The dorsal and posterior limits of the orbits are partially formed by the anterior parts of the frontals. The long parasphenoid extends anteriorly and ventrally to the orbit. The vomer is roughly T-shaped with a wide and oval head and a narrow pointed process extending posteriorly. The anterior part of the skull is broken and twisted to the right resulting in a distorted view.

Jaws The upper jaw is twisted to the right and is only visible in ventral view. Therefore, the shape of the premaxillae is not discernable. Both the premaxillae bear two rows of conical teeth. The dentary bears a series of conical teeth The anguloarticular is rather large. The suture between anguloarticular and retroarticular is not discernable.

Suspensorium The quadrate consists of a large laminar anterior plate and a long curved and posteriorly extending process. The articular process extends antero-ventrally and contacts with the saddle-like facet of the anguloarticular. The symplectic is long and slender. The ectopterygoid extends anterior to the quadrate.

Opercular series The opercular bones are only partially recognizable. The subopercle lacks a distal hook.

Hyoid bar and gill arches The anterior ceratohyal is narrow anteriorly, becoming expanded posterly. The teeth of the lower pharyngeal jaw are visible ventrally to the small left otolith. The teeth of the dorsal pharyngeal jaw form a roundish patch posterior to it. 

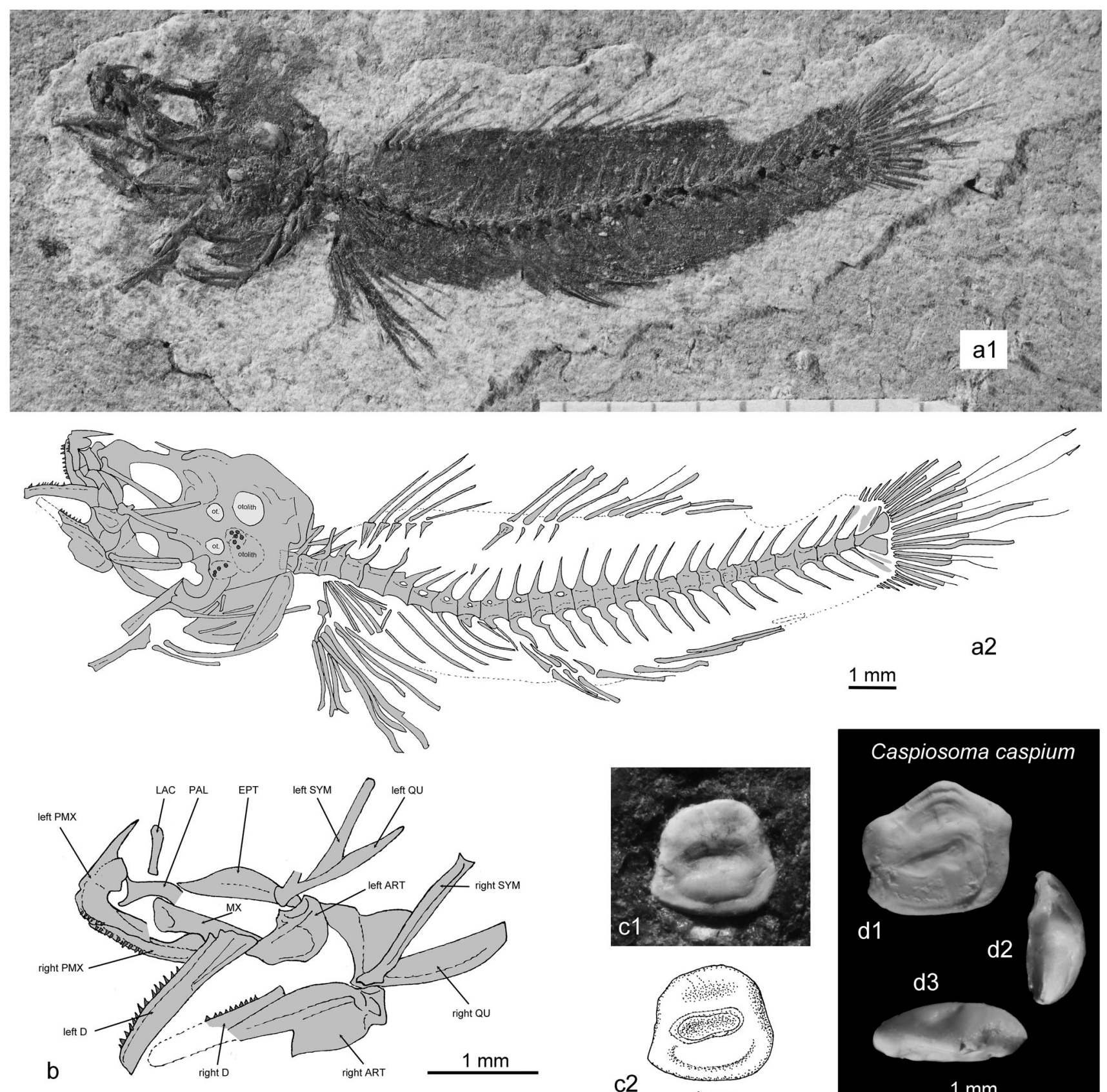

Protobenthophilus squamatus
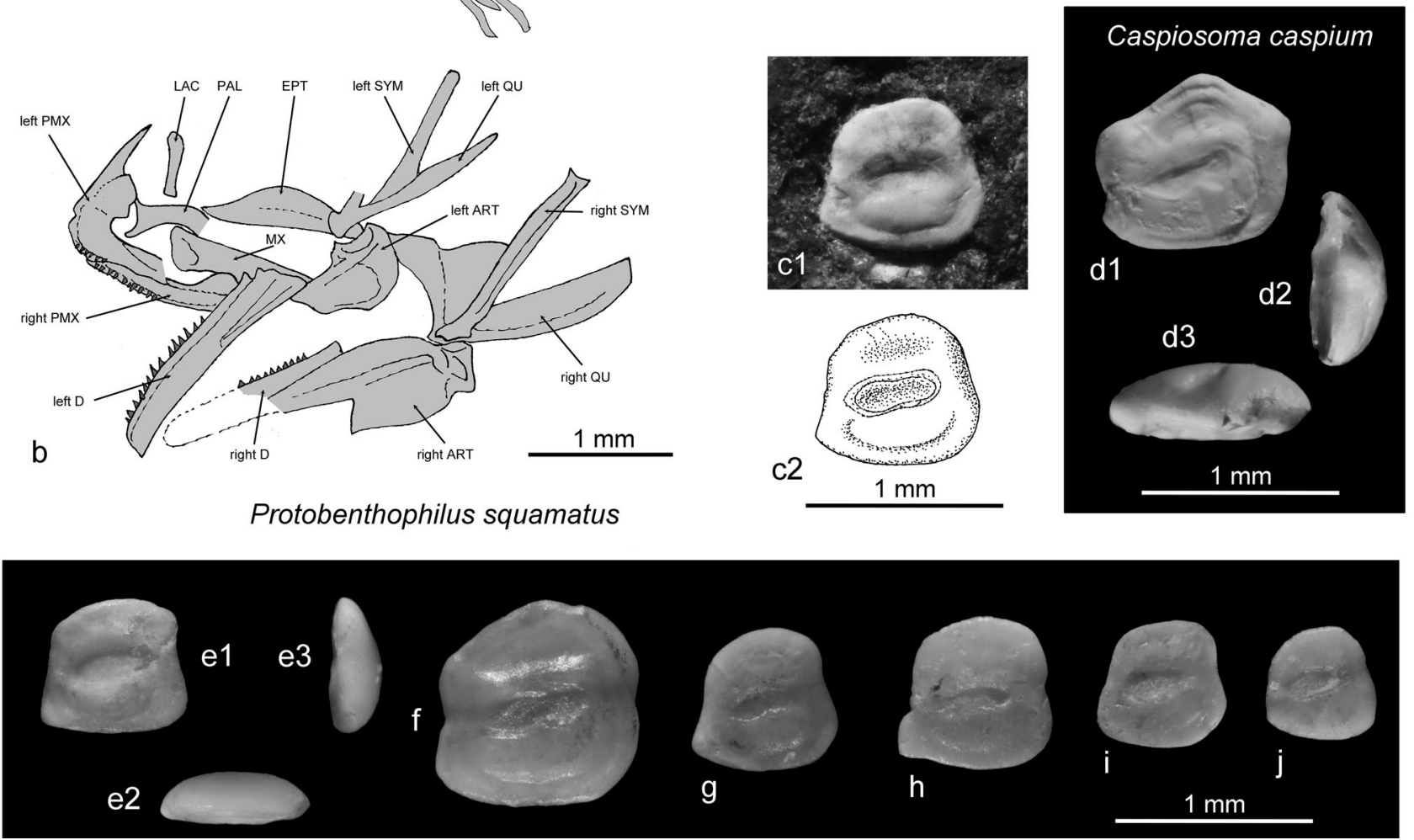
४Fig. 8 Skeleton and otoliths of Protobenthophilus squamatus n.gen. et sp. and otolith of Caspiosoma caspium (Kessler 1877). ac Protobenthophilus squamatus n.sp., holotype, CNHM 272, early Sarmatian s.s., Dolje, Croatia, a articulated skeleton, a1 photograph, a2 interpretative reconstruction, b detail drawing of jaws and suspensorium, c otolith found in situ, c1 photograph, c2 drawing; d otolith of Caspiosoma caspium (Kessler 1877), Recent, ZMMU P.13965 (male specimen), Ukraine, Black Sea, d1 inner face, d2 posterior view, d3 dorsal view; $\mathbf{e}-\mathbf{j}$ isolated otoliths of Protobenthophilus squamatus n.gen. et sp., e SMF P.2872d, Sarmatian s.1., Persunari, Romania, e1 inner face, e2 posterior view, e3 dorsal view, f UMG-X 8578 (mirror imaged), early Sarmatian s.l., Galatin, Bulgaria, g UMG-X 8584, late Sarmatian s.l., Simeonovo B-7, Bulgaria, h, i SMF P.2874, Sarmatian s.l., Persunari, Romania, j SMF P.2871b, Sarmatian s.l., Persunari, Romania

Axial skeleton The vertebral column contains 28 vertebrae of which 10 are abdominal, the first being only partly exposed. The neural and haemal spines are long, narrow and pointed emerging from the anterior part of the centra except for the five preceding the urostyle. Neural and haemal spines of these vertebrae shift their position gradually to the posterior end of the centra. The haemal spine of the second preural centrum is only slightly expanded.

Caudal skeleton The caudal skeleton consists of an autogenous parhypural, two large nearly triangular hypural plates (hypurals $1+2$ and $3+4$ ) and a small fifth hypural 5. A single elongate and rod-like epural is also present. There are 16 principal caudal-fin rays.

Median fins There are two dorsal fins and a single anal fin. The gap between the two dorsal fins is distinct and rather wide. The first dorsal fin has five spines and apparently originates at the level of the fourth abdominal vertebra ending just above the sixth vertebra. The second dorsal fin inserts above the eighth vertebra. The anal fin has two prehaemal pterygiophores and originates three vertebrae behind the second dorsal fin. Two vacant interneural spaces are present between neural spines six to eight.

Paired fins and girdles Pectoral and pelvic girdles are not recognizable. The pelvic-fin rays are long.

Otolith (sagitta) The otoliths are rather small, measuring up to about $1 \mathrm{~mm}$ in length; OL:OH $=0.95-1.05$. OH:OT about 2.8. The outline is subtriangular with the anterior rim inclined backward towards dorsal and the posterior rim is vertical or inclined forward towards dorsal. The dorsal rim is much shorter than the ventral rim, moderately high with rounded pre-and postdorsal angles, and without or with only an incipient postdorsal projection; it is usually highest behind the middle. The ventral rim is nearly flat. The anterior rim is inclined backwards towards dorsal at about $80^{\circ}$, smooth, straight, and with a sharp preventral projection. The posterior rim is vertical to slightly inclined forward towards dorsal, more strongly projecting at the rounded postventral than the postdorsal angle, and straight or with a weak indention above the caudal tip. All the rims are smooth.

The inner face is flat. The sulcus is short, moderately wide, inclined at about 8 to $10^{\circ}$, positioned slightly supramedian and with a rather regularly rounded to ovoid shape with no or only an incipient ventral indention at the ostial-caudal joint. Small specimens of $0.7 \mathrm{~mm}$ length or less usually have no ventral indention of the sulcus. $\mathrm{CoL}: \mathrm{CoH}=2.8-3.3$. The ostium is anteriorly rounded and shows a very low or no ostial lobe. No subcaudal iugum discernable, although a very incipient narrow indication may be visible at times. The sulcus is somewhat deepened. The dorsal field shows a variably expressed depression. The ventral field shows a distinct, regularly curved ventral furrow at moderate distance from the ventral rim of the otolith. The outer face is moderately convex and smooth.

Discussion Protobenthophilus squamatus is known from a single articulated skeleton from Dolje formerly identified by Kramberger as Gobius pullus. Isolated otoliths, however, indicate that this small species probably was quite common in the Sarmatian of the Central Paratethys and western part of the Eastern Paratethys. There are several high bodied and triangular to subtriangular otoliths of contemporaneous species known from the same region. Aphia macrophthalma differs in the deeper ventral rim and higher dorsal rim and the presence of a distinct subcaudal iugum combined with a deepened ostium. Economidichthys triangularis (Weiler 1943) has an even more regular triangular outline, thicker (OL:OH $=2.2-2.5$ vs 2.8 ), with a very short sulcus and the pre- and postventral angles equally pronounced (vs sharp preventral projection and rounded postventral angle). Knopwitschia bulgarica n.sp. lacks the sharp preventral projection (vs reduced rounded angle) and has a much larger and more steeply inclined sulcus $\left(15^{\circ}-20^{\circ}\right.$ vs $\left.8^{\circ}-10^{\circ}\right)$, often with a weak and rather wide subcaudal iugum.

As far as extant taxa are concerned, P. squamatus mostly resembles Caspiosoma caspium (Kessler 1877) (Fig. 8d), which has more elongate otoliths with a pronounced postdorsal angle above the cauda and a somewhat depressed predorsal area.

Protobenthophilus strashimirovi Schwarzhans, Bradić and Bratishko n.sp.

(Figure 5j-1)

Holotype UMG-X 8590, an otolith from Krivodol, Bulgaria, Volhynian (early Sarmatian s.1.), Fig. 51.

Paratypes Four otoliths; UMG-X 8587 (Fig. 5j-k), UMGX 8591, three otoliths from Krivodol, Bulgaria, Volhynian (early Sarmatian s.1.); UMG-X 8592, a single otolith from Galatin, Bulgaria, Volhynian to Bessarabian (early Sarmatian s.l.). 
Table 3 Counts and measurements of Protobenthophilus squamatus n.gen. et sp. and comparison with the extant Caspiosoma caspium (Kessler 1877) and the aggregated extant genus Benthophilus (extant data after Ahnelt et al. 2000; Ahnelt 2003 and Miller 2004)

\begin{tabular}{|c|c|c|c|}
\hline & $\begin{array}{l}\text { Protobentophilus n.gen. squamatus n.sp. } \\
\text { HT-CNHM } 272\end{array}$ & Caspiosoma caspium & Benthophilus spp. \\
\hline SL (mm) & 18.9 & $<46$ & $<94$ \\
\hline Otolith in situ & Yes & & \\
\hline \multicolumn{4}{|l|}{ Meristics } \\
\hline Precaudal vertebrae & 10 & 10 & $9-10$ \\
\hline Total vertebrae & 28 & $27-29$ & $27-31$ \\
\hline D 1 & V & VI (V-VII) & II-IV \\
\hline D 2 & $\mathrm{I}+8$ & $\mathrm{I}+10-13$ & $I+6-10$ \\
\hline A & $\mathrm{I}+8$ & $\mathrm{I}+7-10$ & $I+5-9$ \\
\hline Pectoral & $6+$ & $18-19$ & $15-19$ \\
\hline D1 last ray between NS & NS5-NS6 & NS6-NS7 & NS4-5-NS5-6 \\
\hline Empty neural spines & NS6-NS8 & NS7-NS8 & NS6-7-NS7-8 \\
\hline D2 first PT between NS & NS8-NS9 & NS8-NS9 & NS7-8-NS8-9 \\
\hline Caudal principle & 16 & & $13-14$ \\
\hline Dorsal pterygiophore formula & 3-221001 & $3-221101$ & $3-22100$ or $3-221 * 01 * 1 *$ \\
\hline Anal PT1 opposite to & $\mathrm{D} 2 / 2$ & & $\mathrm{D} 2 / 3$ \\
\hline postmaxillary process on PMX & Present & Present & Present \\
\hline EPU & 1 & 1 & 1 \\
\hline AP & 2 & $?$ & 1 \\
\hline SOP anterior-ventral shape & Smooth & Hook-like & Smooth \\
\hline \multicolumn{4}{|l|}{ Scales } \\
\hline On head & Naked & Naked & Absent (enlarged ossicles) \\
\hline On body & Predorsal naked & Naked & Absent (enlarged ossicles) \\
\hline Type & Ctenoid & - & - \\
\hline Scales along lateral line & $\sim 27$ & - & - \\
\hline Scale size $(\mathrm{mm})$ & $\sim 0.6$ & - & - \\
\hline \multicolumn{4}{|l|}{ Morphometrics (\% of SL) } \\
\hline Head length & 32.0 & $28.5-32$ & $28-43$ \\
\hline Max. body height & 18.8 & $14.5-20.5$ & $14-30$ \\
\hline Orbit diameter & 6.3 & $\sim 7.5$ & $\sim 3$ \\
\hline D1 length & 13.6 & & \\
\hline A length & 8.5 & & \\
\hline $\mathrm{PL}=$ pectoral length & 12.7 & & \\
\hline Predorsal to D1 & 35.5 & $37-42$ & $37-52$ \\
\hline Predorsal to D2 & 52.3 & & \\
\hline Preanal & 60.9 & & \\
\hline Base of D1 & 6.8 & & \\
\hline Base of D2 & 21.0 & $26-34.5$ & $15-30$ \\
\hline Base of $\mathrm{A}$ & 25.5 & & \\
\hline Distance of D1 to D2 & 9.0 & & \\
\hline
\end{tabular}

Etymology Named in honor of the late Boris Strashimirov, pioneer of otolith research in Bulgaria.

Diagnosis $\mathrm{OL}: \mathrm{OH}=1.10-1.15$; preventral projection sharp; postdorsal projection broad and short, not exceeding in length postventral angle; posterior rim vertical, with distinct indention or concavity at level of cauda; ostium with low ostial lobe; no subcaudal iugum, sulcus inclination $13^{\circ}-18^{\circ}$. 
Description The otoliths are small, measuring up to about $1.4 \mathrm{~mm}$ in length (holotype $1.2 \mathrm{~mm}$ ); OH:OT $=2.5-2.7$. The outline is approximately triangular with the anterior rim strongly inclined backward towards dorsal and the posterior rim near vertical. The dorsal rim is shorter than the ventral rim, moderately high, anteriorly depressed, with a broadly rounded mediodorsal angle, and a broad, short, not outward bend postdorsal projection. The ventral rim is nearly flat. The anterior rim shows a sharp preventral projection, is inclined backwards towards dorsal at about $75^{\circ}$, and shows a shallow concavity at the level of the ostium. The posterior rim is vertical, with a postventral projection not expanding further than the broad postdorsal angle, and with a distinct indention or concavity at the level of the cauda. All the rims are smooth or faintly crenulated in part.

The inner face is slightly convex. The sulcus is moderately long, slightly deepened, narrow, inclined at about $13-18^{\circ}$, positioned slightly supramedian, with a poorly distinguished ostium and cauda, and with a small, broad ventral indention at the ostial-caudal joint. $\mathrm{CoL}: \mathrm{CoH}$ $\max =2.7-3.2, \mathrm{CoL}: \mathrm{CoH} \min =3.7-3.9$. The ostium shows a very low lobe, and is anteriorly somewhat tapering or rounded. There is no subcaudal iugum. The dorsal field shows a small depression. The ventral field shows a broad, regularly curved ventral furrow at moderate distance from the ventral rim of the otolith. The outer face is moderately convex and smooth.

Discussion Protobenthophilus strashimorovi shows the typical sulcus morphology and otolith outline found in the genera Protobenthophilus and Benthophilus. We place it with Protobenthophilus because of the sharply pointed preventral projection and the postventral projection not expanding further than the postventral angle, characters which it shares with the type-species P. squamatus. Protobenthophilus strashimirovi differs from $P$. squamatus in having a more elongate shape $(\mathrm{OL}: \mathrm{OH}=1.1-1.15$ vs 0.95-1.05), less reduced sulcus morphology and more developed postdorsal projection combined with a near vertical posterior rim with a distinctive concavity at about the level of the cauda. All the investigated specimens of $P$. strashimirovi are larger than those of $P$. squamatus so that the observed difference of the posterior rim could be an ontogenetic effect. Other characters including the index $\mathrm{OL}: \mathrm{OH}$ are expected to be stable through ontogeny.

Subfamily Gobionellinae Bleeker 1874

Pomatoschistus lineage sensu Agorreta et al. 2013

Genus Economidichthys Bianco, Bullock, Miller and Roubal 1987

Economidichthys altidorsalis Schwarzhans, Bradić and Bratishko n.sp.
(Figure 10a-f)

Holotype SMF PO 91755, an otolith from Schildbach near Hartberg, Styria, Austria, late Sarmatian s.s. (Fig. 10a).

Paratypes 12 otoliths. SMF PO 91756-61, seven otoliths from Schildbach near Hartberg, Styria, Austria, late Sarmatian s.s. (Fig. 10b-d, f); SMF P.2872e, PO 91762-64, five otoliths from Persunari, Romania, unspecified Sarmatian (Fig. 10e).

Etymology Combination of altus (Latin) = high and dorsalis (Latin) $=$ dorsal, referring to the compressed outline and high dorsal rim.

Diagnosis $\mathrm{OL}: \mathrm{OH}=0.82-0.85$; high and broad dorsal rim, slightly forward inclined; posterior rim with broad, rounded, expanded postventral angle; ostium narrow; small subcaudal iugum. OL:SuL $=1.6-1.9$; sulcus inclination $15^{\circ}-22^{\circ}$.

Description The otoliths are small, high bodied reaching about $0.8 \mathrm{~mm}$ in length (holotype $0.7 \mathrm{~mm}$ ). $\mathrm{OH}: \mathrm{OT}=2.8-3.2$. The dorsal rim is markedly expanded, its highest point at about its midlength, and appearing forward inclined because of the near vertical anterior and the inclined posterior rims. The ventral rim is moderately deeply curved, often somewhat undulating. The anterior rim shows a variably pointed or rounded preventral angle and a broadly rounded predorsal angle, both projecting to similar levels or dorsally projecting slightly further. An indention is sometimes visible above the level of the ostial tip. The posterior rim is slightly forward inclined towards dorsal at an angle of $75^{\circ}-85^{\circ}$, being straight or, more commonly, with an angular incision above the level of the cauda. The postdorsal angle is broad, short, and projecting less than the broadly rounded postventral angle.

The inner face is flat. The sulcus is moderately long, narrow, inclined at about $15^{\circ}-22^{\circ}$, positioned slightly supramedian, and with a small, narrow subcaudal iugum. CoL:CoH $\max =3.5-3.8, \mathrm{CoL}: \mathrm{CoH} \min =5-9$. The ostium shows a low lobe, is highest close to the cauda, and anteriorly tapering and pointed. The dorsal field is high with a small, indistinct depression. The ventral field shows a broad, regularly curved ventral furrow at moderate distance from the ventral rim of the otolith. The outer face is moderately convex and smooth.

Discussion Economidichthys altidorsalis differs from $E$. triangularis primarily in the more compressed outline (OL:OH $=0.82-0.85$ vs $0.9-1.05)$ and the longer sulcus (OL:SuL $=1.6-2.0$ vs 2.2-2.4). The triangular sometimes forward inclined outline with the massive dorsal field appears to be typical for the genus. Economidichthys altidorsalis also shows a rather large degree of variability (like E. triangularis), which is primarily evidenced in the 

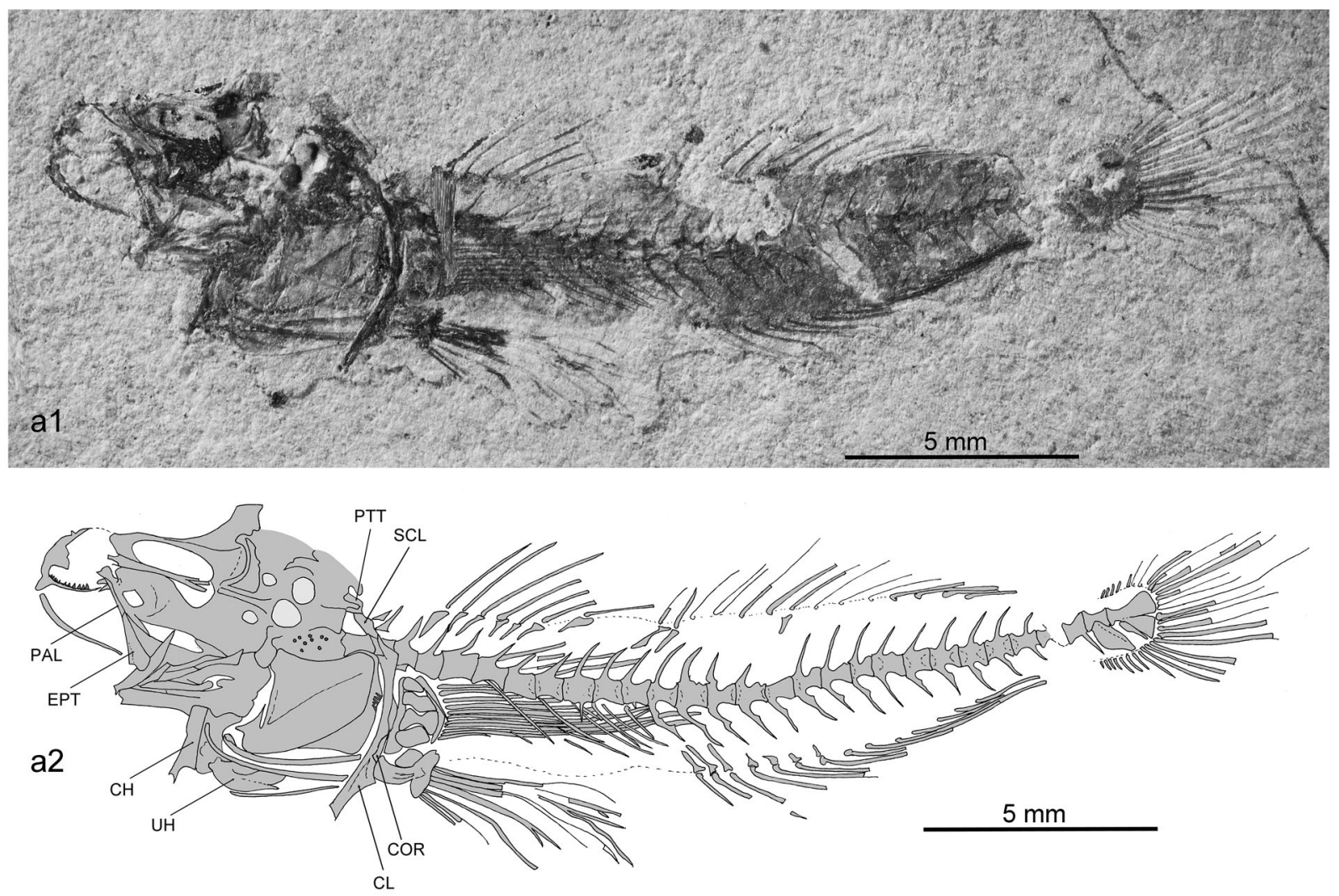

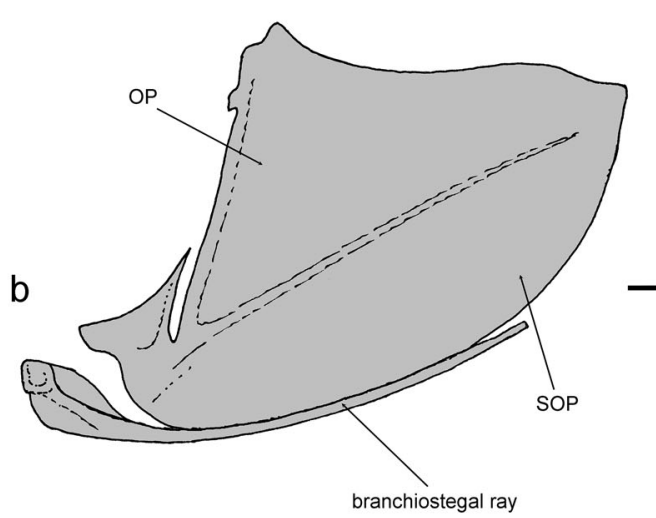

Economidichthys triangularis

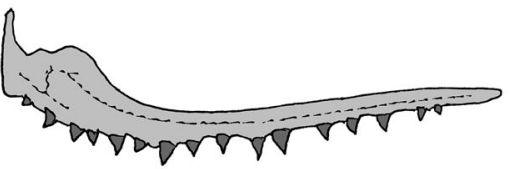

C

$1 \mathrm{~mm}$

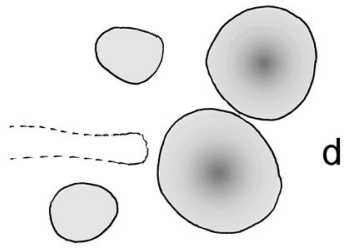

$1 \mathrm{~mm}$

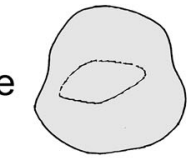

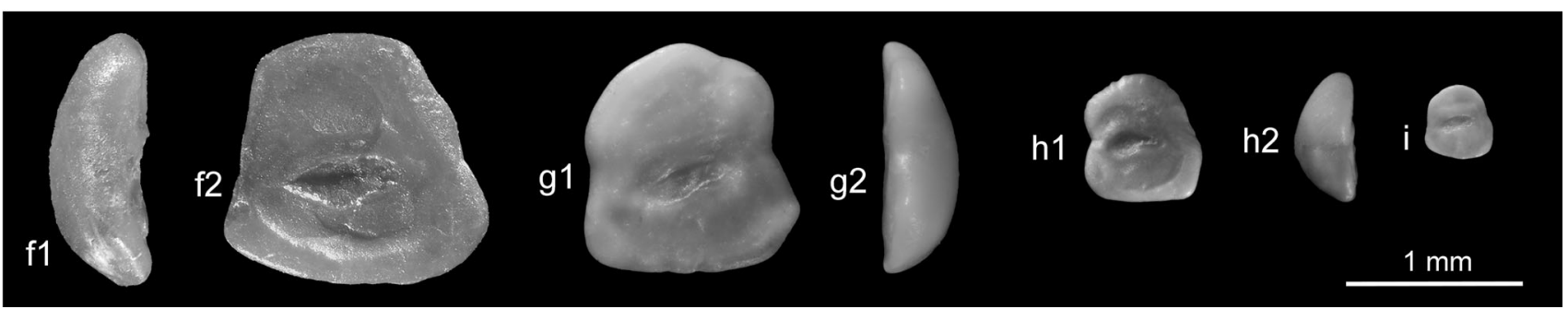


४Fig. 9 Economidichthys triangularis (Weiler, 1943). CNHM 231 and CNHM 232, early Sarmatian s.s., Dolje, Croatia, a merger of plate (CNHM 231) and counterplate (CNHM 232) of articulated skeleton, a1 photograph, a2 interpretative reconstruction, b detail drawing of opercle and subopercle, $\mathbf{c}$ detail drawing of premaxillary, $\mathbf{d}$ sketch of imprints of outer faces of otoliths, e sketch of imprint of inner face of right sagittal otolith; isolated otoliths, f holotype, SMF P.2651a, late Badenian, Salcia, Romania, $\mathbf{f} 1$ anterior view, $\mathbf{f} 2$ inner face, $\mathbf{g}$ SMF PO 91768, early Sarmatian s.s., Wildon, Austria, g1 inner face, g2 posterior view, $\mathbf{h}$ refigured specimen from Schwarzhans, Bradić and Rundić (2015), early Sarmatian, Barajevo-3 well, 40-43 m, Serbia, h1 inner face, h2 anterior view, i SMF P.2872a, Sarmatian s.1., Persunari, Romania

expression of the indentations of the anterior and posterior rims, which can be significant to absent. Also the sharpness or roundness of the preventral angle varies considerably. The otoliths from Persunari, Romania, differ from those of Schildbach, Austria, in the somewhat shorter sulcus (OL:SuL $=1.8-2.0$ vs 1.6-1.85), which is also less clearly structured. However, it is not possible to define whether this could be a regional variation or have stratigraphic relevance, because no detailed stratigraphic information is available. In any case, we consider this small difference to be an expression of variability, based on the presently available material.

Economidichthys altidorsalis is known from two localities. In the late Sarmatian s.s. of Schildbach, Styria in Austria, it represents the most common species. Its congener $E$. triangularis has not been recognized from Schildbach. At Persunari, Romania, however, it co-occurs with E. triangularis. Economidichthys triangularis is more widely distributed than E. altidorsalis and appears to be occurring earlier as well, i.e., since late Badenian, possibly early Badenian. We assume that E. altidorsalis may have been adapted to a more confined environment than $E$. triangularis.

Economidichthys triangularis (Weiler 1943)

(Figure 9a-i; Table 4)

?1906 Otolithus (Gobius) intimus Prochazka 1893.Schubert: pl. 6, fig. 36 (non 35, 37).

1943 Gobius triangularis Weiler.-Weiler: pl. 1, figs. 25-26.

1949 Gobius triangularis Weiler 1943.-Weiler: pl. 3, fig. 25, pl. 4, fig. 26.

1962 Gobius triangularis Weiler 1943.-Paghida: pl. 2, fig. 4.

?1968 Gobius intimus Prochazka 1893.-Rado: pl. 4, fig. 3 .

?1968 Otolithus (Gobius) sarmatus Suzin (in Zhizhenko).-Suzin: pl. 17, fig. 2; (name not available: ICZN article 13.1.1).
1968 Otolithus (Gobius) tenuis Suzin (in Zhizhenko).Suzin: pl. 17, fig. 5; (name not available: ICZN article 13.1.1).

1970 Gobius triangularis Weiler 1943.-Stancu: pl. 1, figs. 1-3, 5 (non fig. 4).

1974 Gobius triangularis Weiler 1943.-Brzobohaty and Stancu: pl. 2, figs. 1-5, 9-10 (figs. 6-8 ?).

?1982 Gobius triangularis Weiler 1943.-Strashimirov: pl. 2, figs. 5-10, ?11-14.

2006 Gobius triangularis Weiler 1943.-Djafarova: pl. 19, fig. 5, pl. 20, figs. 1-2 (non figs. 3-4).

2010 Trimma triangularis (Weiler 1943).--Schwarzhans: pl. 104, fig. 6 .

2015 Economidichthys triangularis (Weiler 1943).- Schwarzhans, Bradić and Rundić: figs. 6.4-6.6.

Material CNHM 231 and 232, a single specimen measuring $23.5 \mathrm{~mm}$ SL (Fig. 9a-e) with saccular otoliths represented as impression only, in part and counterpart, Dolje, Croatia, Sarmatian s.s. (Volhynian). Five isolated otoliths; SMF PO 91768 (Fig. 9g), a single, tentatively assigned otolith from Wildon, Styria, early Sarmatian s.s.; SMF P.2872a, SMF PO 91765-67 (Fig. 9i), four otoliths from Persunari, Romania, Sarmatian.

Diagnosis Gobiid fish of small size with $29(11+18)$ vertebrae (including urostyle); first dorsal fin contains seven spines; second dorsal fin and anal fin with a single spine plus 13 rays; dorsal pterygiophore formula 312310001; postmaxillary process of the premaxilla absent; head, nape and anterior back naked; scales mostly cycloid; $\mathrm{OL}: \mathrm{OH}=0.9-1.05$; otolith with triangular outline, without postdorsal process; $\mathrm{OL}: \mathrm{SuL}=2.2-2.4$; narrow and small subcaudal iugum; sulcus inclination $5^{\circ}-13^{\circ}$.

Description Counts and measurements are reported in Table 4.

Neurocranium The skull is badly damaged; its posterior part is crushed. The thin and long parasphenoid is the only recognizable bone of the neurocranium.

Jaws The premaxilla has rather short ascending and articular process; the postmaxillary process is absent (Fig. 9c), representing a diagnostic feature of the sand gobies. The left maxilla is located more or less parallel to the parasphenoid. The posterior most part of the right mandible is visible with the articulation facet for the quadrate.

Suspensorium The quadrate shows an anterior bony lamina and a long posterior process. Anterior to the quadrate, it is possible to recognize the ectopterygoid and the palatine.

Opercular series. The opercle and subopercle are large and well discernable. The opercle is of triangular shape, and the postero-ventrally located subopercle shows a 
Table 4 Counts and measurements of Economidichthys triangularis (Weiler 1943) and Pomatischistus sp. (after Carnevale et al. 2006) and comparison with the extant Economidichthys pygmaeus (Holly
1929), Hyrcanogobius bergi Iljin 1928 and the aggregated extant genera Knipowitschia and Pomatoschistus (extant data after Miller 2004 and Mestermann and Zander 1984)

\begin{tabular}{|c|c|c|c|c|c|c|}
\hline & $\begin{array}{l}\text { Economidichthys } \\
\text { triangularis } \\
\text { CNHM 231/232 }\end{array}$ & $\begin{array}{l}\text { Pomatoschistus } \\
\text { sp. } \\
\text { After Carnevale } \\
\text { et al. (2006) }\end{array}$ & $\begin{array}{l}\text { Economidichthys } \\
\text { pygmaeus }\end{array}$ & $\begin{array}{l}\text { Hyrcanogobius } \\
\text { bergi }\end{array}$ & Knipowitschia spp. & $\begin{array}{l}\text { Pomatoschistus } \\
\text { spp. }\end{array}$ \\
\hline $\mathrm{SL}(\mathrm{mm})$ & 23.5 & 22.3 & $<43$ & $<37$ & $<50$ & $<65$ \\
\hline Otolith in situ & Imprint & Yes & & & & \\
\hline \multicolumn{7}{|l|}{ Meristics } \\
\hline $\begin{array}{l}\text { Precaudal } \\
\text { vertebrae }\end{array}$ & 11 & 12 & $12-13$ & $?$ & $11-12$ & $11-13$ \\
\hline Total vertebrae & 29 & 32 & $29-31$ & $?$ & $30-33$ & $30-33$ \\
\hline D 1 & VII & VI & VI (V-VI) & VI (VI-VII) & VI (V-VII) & VI (V-VII) \\
\hline D 2 & $\mathrm{I}+13$ & $\mathrm{I}+11$ & $\mathrm{I}+8-11$ & $I+7-9$ & $I+6-9$ & $I+6-12$ \\
\hline A & $\mathrm{I}+13$ & $\mathrm{I}+10$ or 11 & $I+7-10$ & $I+7-9$ & $\mathrm{I}+7-10$ & $I+6-12$ \\
\hline Pectoral & $15-16$ & $\mathrm{~nm}$ & $13-19$ & $15-18$ & $15-19$ & $15-21$ \\
\hline $\begin{array}{l}\text { D1 last ray } \\
\text { between NS }\end{array}$ & NS6-NS7 & & NS6-NS7 & NS6-NS7 & NS6-NS7 & NS6-NS7 \\
\hline $\begin{array}{l}\text { empty neural } \\
\text { spines }\end{array}$ & NS7-NS10 & & $\begin{array}{l}\text { NS7-NS9 to } \\
\text { NS7-NS10 }\end{array}$ & NS7-NS9 & $\begin{array}{l}\text { NS8-NS19 to NS7- } \\
\quad \text { NS10 }\end{array}$ & NS7-NS10 \\
\hline $\begin{array}{l}\text { D2 first PT } \\
\text { between NS }\end{array}$ & NS10-NS11 & & $\begin{array}{l}\text { NS9-NS10 to } \\
\text { NS10-NS11 }\end{array}$ & NS9-NS10 & $\begin{array}{l}\text { NS9-NS10 to } \\
\text { NS10-NS11 }\end{array}$ & NS10-NS11 \\
\hline Caudal principle & 16 & 15 & $15-16$ & & 15 & $16-20$ \\
\hline $\begin{array}{l}\text { Dorsal } \\
\text { pterygiophore } \\
\text { formula }\end{array}$ & 3-12310001 & $3-1 \ldots$ & $3-1221001$ & $3-1221001$ & $\begin{array}{l}3-1221001 \text { to } \\
3-12201001\end{array}$ & $3-122100(0) 1$ \\
\hline $\begin{array}{l}\text { Anal PT1 } \\
\text { opposite to }\end{array}$ & $\mathrm{D} 2 / 1$ & & $\mathrm{D} 2 / 3$ & $\mathrm{D} 2 / 3$ & $\mathrm{D} 2 / 3$ & $\mathrm{D} 2 / 3$ \\
\hline $\begin{array}{l}\text { Postmaxillary } \\
\text { process on } \\
\text { PMX }\end{array}$ & Absent & & Absent & Absent & Absent & absent \\
\hline EPU & nv & 1 & 1 & 1 & 1 & 1 \\
\hline AP & 1 or 2 & & $?$ & $?$ & 2 & 2 \\
\hline $\begin{array}{l}\text { SOP anterior- } \\
\text { ventral shape }\end{array}$ & Hook-like & & Hook-like & Hook-like & Hook-like & Hook-like \\
\hline \multicolumn{7}{|l|}{ Scales } \\
\hline On head & Naked & & Naked & Naked & Naked & Naked \\
\hline On body & $\begin{array}{l}\text { Predorsal and } \\
\text { anterior back } \\
\text { naked }\end{array}$ & & $\begin{array}{l}\text { Back and } \\
\quad \text { abdomen } \\
\text { naked }\end{array}$ & $\begin{array}{l}\text { Back and } \\
\text { abdomen } \\
\text { naked }\end{array}$ & $\begin{array}{l}\text { Predorsal and } \\
\text { anterior back } \\
\text { naked }\end{array}$ & $\begin{array}{l}\text { Predorsal naked, } \\
\text { occ. scaled }\end{array}$ \\
\hline Type & Mostly cycloid & & Ctenoid & Ctenoid & Ctenoid & Ctenoid \\
\hline $\begin{array}{l}\text { Scales along } \\
\text { lateral line }\end{array}$ & $\sim 35$ & & $30-38$ & $23-31$ & $30-33$ & $36-75$ \\
\hline Scale size $(\mathrm{mm})$ & 0.5 & & & & & \\
\hline \multicolumn{7}{|c|}{ Morphometrics (\% of SL) } \\
\hline Head length & 32.5 & & $25-30$ & $26-32$ & $23.5-29$ & $23-28$ \\
\hline Max. Body height & 15.4 & & $20.5-25.5$ & $16.5-21$ & $17.5-24$ & $16-19$ \\
\hline Orbit diameter & 6.5 & & $\sim 7$ & $6-7$ & $6.5-7.5$ & $6-6.5$ \\
\hline D1 length & 12.4 & & & & & \\
\hline A length & 9.5 & & & & & \\
\hline $\begin{array}{l}\mathrm{PL}=\text { pectoral } \\
\text { length }\end{array}$ & 23.3 & & $16.5-19.0$ & & $16-22$ & \\
\hline Predorsal to D1 & 35.0 & & $37-41$ & $34-39.5$ & $34.5-40$ & $31-37$ \\
\hline Predorsal to D2 & 55.2 & & $54-61$ & $52.5-55$ & $52.0-60.5$ & $49-58$ \\
\hline
\end{tabular}


Table 4 continued

\begin{tabular}{lllllll}
\hline & $\begin{array}{l}\text { Economidichthys } \\
\text { triangularis } \\
\text { CNHM 231/232 }\end{array}$ & $\begin{array}{l}\text { Pomatoschistus } \\
\text { sp. } \\
\text { After Carnevale } \\
\text { et al. (2006) }\end{array}$ & $\begin{array}{l}\text { Economidichthys } \\
\text { pygmaeus }\end{array}$ & $\begin{array}{l}\text { Hyrcanogobius } \\
\text { bergi }\end{array}$ & $\begin{array}{l}\text { Knipowitschia spp. } \\
\text { Pomatoschistus } \\
\text { spp. }\end{array}$ \\
\hline Preanal & 60.5 & & $60-70$ & $54-57.5$ & $55.5-65$ & $54-58$ \\
Base of D1 & 12.8 & & $9-14$ & $8.5-10.5$ & $7-11$ & $9.5-12$ \\
Base of D2 & 27.6 & $15-21$ & $13.5-18.5$ & $13-18$ & $17-22$ \\
$\begin{array}{l}\text { Base of A } \\
\text { distance of D1 to }\end{array}$ & 27.1 & & $10-18$ & $12.5-15.5$ & $12.5-16$ & $15-20$ \\
D2 & & $6-10$ & & $6.5-13$ & \\
\end{tabular}

distinct hook. The interopercle and preopercle are not discernable.

Hyoid bar and gill arches The hyoid bar supports seven branchiostegal rays. The urohyal is cup shaped anterodorsally at the level of the contact with the first basibranchial; posteriorly, it extends forming a laminar compressed main body. Of the gill arches, a patch of pharyngobranchial teeth is exposed immediately dorsal to the opercle. The lower pharyngeal jaw (ceratobranchial 5) is oriented vertically immediately anterior to the cleithrum.

Axial skeleton The vertebral column consists of 29 $(11+18)$ vertebrae including the urostyle. The neural and haemal spines are long, narrow and pointed and originate on the anterior part of each centrum except for the seven preceding the urostyle. The haemal spine of the second preural vertebra is notably expanded.

Caudal skeleton The caudal skeleton is inadequately preserved. There are 16 principal caudal rays.

Median fins There are two dorsal fins and a single anal fin. There is a distinct gap between the two dorsal fins. The first dorsal fin comprises seven spines and originates just above the fourth vertebra ending at the level of the seventh abdominal vertebra. The second dorsal fin inserts above the tenth abdominal vertebra. There are two prehaemal anal-fin pterygiophores, the second of which is opposite the tip of the first haemal spine and originates at the level of one vertebra posterior to the second dorsal-fin origin. There are three vacant interneural spaces between the neural spines of the vertebrae seven to ten.

Paired fins and girdles The pectoral fin is supported by four ovoid radials. The cleithrum is crescent shaped. The posttemporal and supracleithrum are partially recognizable. The coracoid is rather small. The pelvic fin contains a short spine and five rays.

Otolith (sagitta) The otoliths are small, high bodied measuring up to about $1.8 \mathrm{~mm}$ in length (holotype $1.5 \mathrm{~mm}$ ), with triangular outline; $\mathrm{OH}: \mathrm{OT}=2.2-2.6$. The dorsal rim is high, flat or rounded, without postdorsal projection. The ventral rim is rather shallow, with a rounded or angular preventral angle and a broadly rounded postventral angle. The anterior and posterior rims are inclined upwards, the anterior rim at angle of $75^{\circ}-85^{\circ}$, the posterior rim at angle of $65^{\circ}-80^{\circ}$; occasionally, there is a slight incision of the anterior rim at the level of the ostium.

The inner face is flat. The sulcus is short, moderately wide, inclined at about $5^{\circ}-13^{\circ}$, positioned slightly supramedian and with a small, narrow, weak subcaudal iugum, usually below the entire cauda. CoL:CoH $\max =2.5-3.0$, CoL:CoH min $=3.5-5$. The ostium shows a low lobe; it is equally strongly curved ventrally, and anteriorly tapering, rounded or pointed. The cauda is very narrow. The dorsal field is high with a large, wide depression. The ventral field shows a wide, distinct ventral furrow at considerable distance from the ventral rim of the otolith. The outer face is convex and smooth.

Discussion The morphological analysis of the moderately well-preserved CNHM 231/232 reveals that it is a member of the sand gobies (Pomatoschictus lineage) because of the lack of a postmaxillary process in the premaxilla, dorsal pterygiophore formula starting with 3-1231, and three vacant interneural spaces between first and second dorsal fins. It shares a low vertebral number (29) with Economidichthys (29-31), while the other sand goby genera have 30-33 vertebrae. This trait and the high bodied otolith in correlation with isolated otolith finds (see below) were taken as main arguments for the generic placement of $E$. triangularis. Other characters diagnostic of Economidichthys, including those described by Bianco et al. (1987) and Economidis and Miller (1990) are not preserved in fossils (neuromasts and perianal organ). Recent species of the genus Economidichthys are restricted to the freshwaters of the Dinarids and Greece. The early occurrence of marine to brackish marine species of the genus in the Middle Miocene (Badenian and Sarmatian) of the 


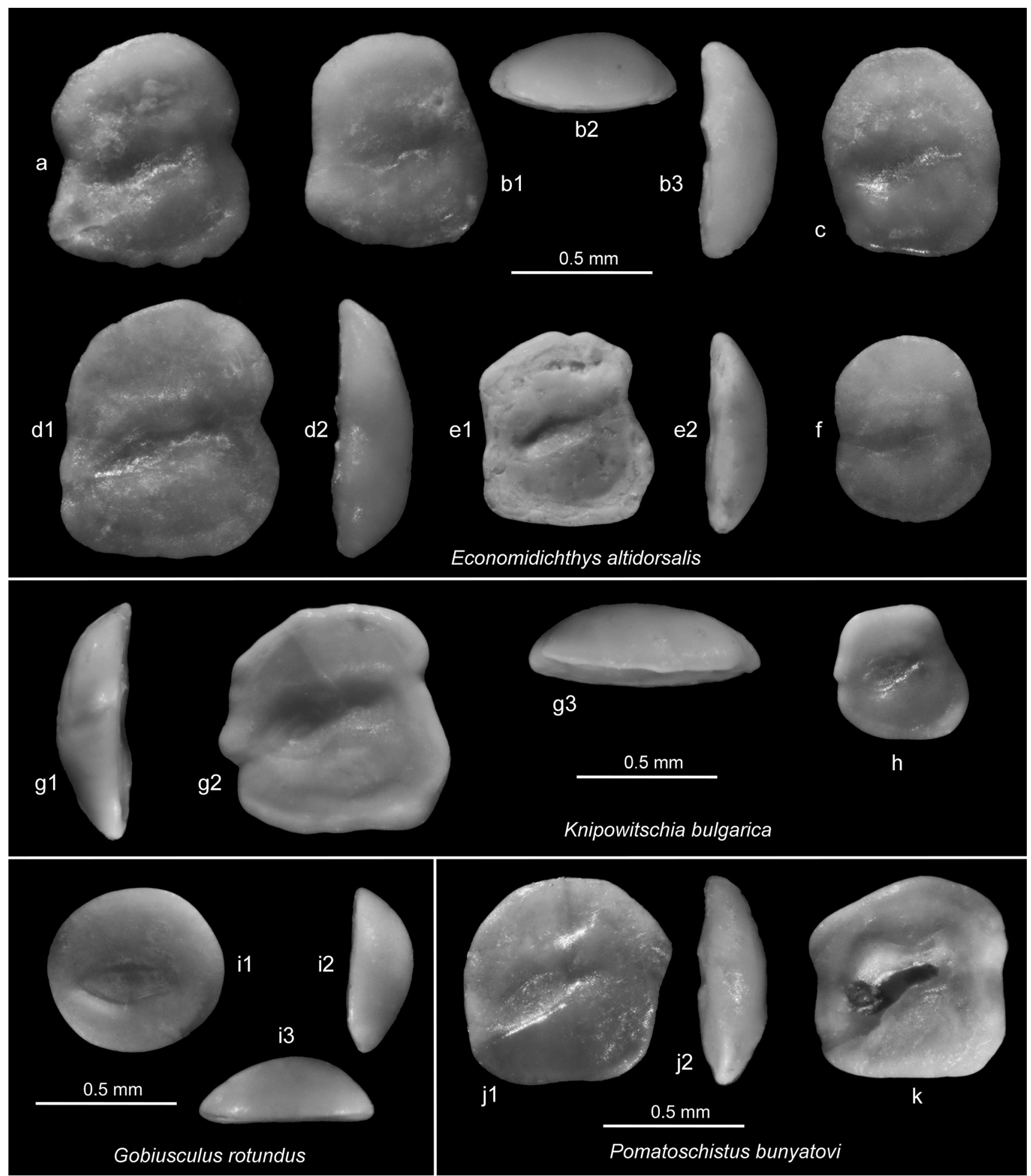


४Fig. 10 Otoliths of Economidichthys, Gobiusculus, Knipowitschia and Pomatoschistus. a-f Economidichthys altidorsalis n.sp., late Sarmatian s.s., Schildbach near Hartberg, Austria, a holotype, SMF PO 91755, b paratype, SMF PO 91756, b1 inner face, b2 dorsal view, b3 posterior view, c paratype, SMF PO 91759 (mirror imaged), d paratype, SMF PO 91757, d1 inner face, d2 posterior view, f paratype, SMF PO 91758 (mirror imaged); e paratype, SMF PO 91763, Sarmatian s.1., Persunari, Romania, e1 inner face, e2 posterior view; g, h Knipowitschia bulgarica n.sp., late Sarmatian s.l., Simeonovo B-7, Bulgaria, g holotype, UMG-X 8596 (mirror imaged), g1 anterior view, $\mathbf{g} 2$ inner face, $\mathbf{g 3}$ dorsal view, h paratype, UMG-X 8597; i Gobiusculus rotundus (Pobedina 1954), Tarkhanian, Goren Bliznak well C-2, 143.4-145.3 m, Bulgaria (mirror imaged), i1 inner face, i2 posterior view, $\mathbf{i} 3$ dorsal view; $\mathbf{j}$, $\mathbf{k}$ Pomatoschistus bunyatovi Bratishko, Schwarzhans and Reichenbacher 2015, j SMF PO 91771, late Sarmatian s.s., Kostel-1, 398.6-405.6 m, Czech Republic, j1 inner face, $\mathbf{j} 2$ posterior view, $\mathbf{k}$ refigured specimen from Schwarzhans, Bradić and Rundić (2015), early Sarmatian s.s., Barajevo-1, 20-25 m, Serbia

Paratethys is consistent with the recent molecular phylogenetic analysis by Malavasi et al. (2012), who placed Economidichthys occupying a basal position within the sand gobies. With its first appearance in late Badenian and possibly early Badenian, E. triangularis is indeed the earliest confirmed record of any Ponto-Caspian endemic goby known to date.

The correlation of the well-preserved articulated skeleton from Dolje with the otolith-based species first described by Weiler (1943) is somewhat hampered by the fact that both the originally present otoliths are not preserved. The right slab shows both saccular otoliths as clear, nearly round, partial impressions of the convex outer face and also two feeble small impressions of the utricular otoliths (Fig. 9d). The left slab shows one of the two counterparts of a saccular otolith with a delicate impression of the inner face. The outline is roughly triangular at a length to height ratio of about 1.0 with a feeble indication of a short, oval sulcus at the center (Fig. 9e). The imprint is not good enough for a detailed description. However, E. triangularis is the only Sarmatian taxon showing this regular triangular otolith outline and proportions. Otoliths of E. altidorsalis are higher, whereas Knipowitschia bulgarica has a reduced preventral angle, and other morphologically similar otolithbased species are already linked with other articulated skeletons, i.e., Aphia macropthalma, Protobenthophilus squamatus and Hesperichthys reductus n.gen. et sp. Therefore, we are confident that the skeleton of CNHM 231/232 can be securely associated with the otolith-based species E. triangularis (Weiler 1943).

Genus Gobiusculus Duncker 1928

Gobiusculus rotundus (Pobedina 1954)

(Figure 10i)

1954 Otolithus (Gobius) rotundus Pobedina.-Pobedina: pl. 2, fig. 4 .
1954 Otolithus (Gobius) rotundus tarchanicus Pobedina.Pobedina: pl. 3, fig. 1.

1956 Otolithus (Gobius) rotundus Pobedina 1954.-Pobedina: pl. 2, fig. 1.

1956 Otolithus (Gobius) rotundus tarchanicus Pobedina 1954.-_Pobedina: pl. 2, fig. 2.

1972 Otolithus (Clupea) cancasicus Suzin 1968.-Strashimirov: pl. 1, figs. 1-2.

1972 Otolithus (Gobius) rotundus Pobedina 1954.-Strashimirov: pl. 1, figs. 3-4, ?fig. 5-6.

1972 Otolithus (Gobius) rotundus tarchanicus Pobedina 1954.-Strashimirov: pl. 1, fig. 7-8.

1980 Gobius rotundus tchokrakensis Strashimirov.-Strashimirov: pl. 1, fig. 3.

2006 Gobius rotundus Pobedina 1954.-Djafarova: pl. 21, figs. 3-6.

2006 Gobius rotundus tarchanicus Pobdeina 1954.-Djafarova: pl. 22, figs. 4-7.

Material Eight Tarkhanian (early Badenian) otoliths. Seven otoliths from Goren Bliznak well C-2, Bulgaria; UMG-X 8546, two otoliths from 106.6 to 107.3 m; UMG-X 8593, four otoliths from 143.4 to $145.3 \mathrm{~m}$; UMG-X 8549, a single otolith from 158.45 to 158.65 m; UMG-X 8550, a single otolith from Dolen Bliznak well C-5, Bulgaria, $25 \mathrm{~m}$, Tshokrakian (early Badenian).

Description These otoliths are small, nearly circular in outline and reach sizes just slightly more than $0.5 \mathrm{~mm}$ in length. $\mathrm{OL}: \mathrm{OH}=1.05$ in the largest, figured specimen; $\mathrm{OH}: \mathrm{OT}=2.5$. The inner face is flat; the outer face is convex and smooth. The sulcus on the inner face is inframedian and slightly deepened. $\mathrm{OL}: \mathrm{SuL}=1.75$ in the largest, figured specimen. The outline of the sulcus is reduced with a pointed ostial tip, not much resembling the typical gobiid sole-shaped sulcus. It is widest slightly behind the middle and shows a rounded caudal termination. The ostial lobe is low. There is no subcaudal iugum. A dorsal depression is not recognizable. The weak ventral furrow runs close to the ventral rim of the otolith.

Discussion Otoliths of the genus Gobiusculus are certainly amongst the morphologically most reduced found within the gobiids. They are also very small and in many instances it is not clear whether a given specimen is a representative of Gobiusculus or an otolith of a larval stage of some other goby. In the case of the G. rotundus specimens studied here, only the 'largest' specimen of about $0.5 \mathrm{~mm}$ length can be confidently assigned, while all the other specimens of sizes of about $0.2-0.3 \mathrm{~mm}$ length might represent otolith of larval individuals. They are referred herein to $G$. rotundus primarily because of their occurrence in the same general area and stratigraphic interval. 
Gobiusculus rotundus is characterized by an extremely reduced otolith morphology, with the sulcus so much generalized that their recognition as a member of the Gobioidei can be difficult at times. Gobiusculus verus Schwarzhans and Wienrich 2009 from the Early to Middle Miocene of the North Sea Basin is similar, but differs in the more uniformly narrow and anteriorly not pointed sulcus, as well as the distinct ventral furrow being located half way between ventral rim of otolith and sulcus. Gobiusculus rotundus differs from the Recent G. flavescens (Fabricius 1779) in a slightly less compressed outline and the absence of a narrow subcaudal iugum (Härkönen 1986).

Gobiusculus rotundus (originally including two subspecies, which are not recognized herein) has been recorded regularly from the Tarkhanian and Tshokrakian of the Eastern Paratethys. There are no records from outside of the Eastern Paratethys. Also, there are no verified records from younger strata, i.e., Konkian or Sarmatian. Records in Djafarova (2006) from the Sarmatian of Azerbaijan are not figured and the specimens were not available for review. We, therefore, assume that G. rotundus represented a species possibly endemic to the fully marine environments of the Tarkhanian to Tshokrakian of the Eastern Paratethys that became extinct from the area as a consequence of the catastrophic Karaganian event.

Genus Hesperichthys Schwarzhans, Ahnelt, Carnevale and Japundžić n.gen.

Type species Hesperichthys reductus Schwarzhans, Ahnelt, Carnevale and Japundžić n.sp.

Etymology From hesperis $($ Latin $)=$ westerly, referring to the occurrence in the western part of the former Paratethys, e.g., in the Central Paratethys and western part of the Eastern Paratethys.

Diagnosis A genus of the family Gobiidae, subfamily Gobionellinae characterized by the following combination of characters: $29(11+18)$ vertebrae; first dorsal fin with six spines, second dorsal fin with a single spine plus nine rays; anal fin with a single spine plus ten rays; last pterygiophore of first dorsal fin located between neural spines of the sixth and seventh abdominal vertebrae; vacant interneural spaces between neural spines of the vertebrae seven to 11; first pterygiophore of second dorsal fin between neural spines of the vertebrae 11 and 12; dorsal pterygiophore formula $3-311100001$ or $3-12111 \ldots$; first anal-fin pterygiophore opposite to the first pterygiophore of second dorsal fin; a single epural; two anal-fin pterygiophores in front of first haemal spine; body scaled on trunk at least backwards to the pelvic fin base; head naked; scales mostly cycloid, more than 31 scales along lateral line; second dorsal fin long-based ( $27 \%$ of SL); pectoral and
Fig. 11 Hesperichthys n.gen. a-k Skeletons and otoliths of Hesperichthys reductus n.gen et sp., early Sarmatian s.s., Dolje, Croatia, a-c, $\mathbf{g}$ holotype, CNHM 149, a photograph of the articulated skeleton, b detail drawing of abdominal vertebrae column and associated fins, c detail drawing of suspensorium and opercular series, $\mathbf{g}$ drawing of extracted right otolith, g1 inner face, $\mathbf{g} 2$ anterior view, paratype, CNHM 271, d detail drawing of dentary, e photograph of partially preserved articulated skeleton, $\mathbf{f}$ otoliths in situ, f1 photograph, f2 drawing; $\mathbf{h}-\mathbf{k}$ isolated otoliths of Hesperichthys reductus n.gen. et sp., h SMF PO 91770, Sarmatian s.s., Gbely well 358, 20.8-21.9 m, Slovakia, h1 inner face, $\mathbf{h} 2$ dorsal view, $\mathbf{h} 3$ posterior view, i-k UMGX 8594, early Sarmatian s.1., Galatin, Bulgaria, i1, j1 inner face, i2, j2 dorsal view, $\mathbf{j} \mathbf{3}$ posterior view; $\mathbf{l}-\mathbf{n}$ isolated otoliths of Hesperichthys hesperis (Schwarzhans, Bradic and Rundic 2015), I holotype IGOTBAB4/1, Sarmatian s.s., Barajevo-4, 10-12 m, m paratype IGOTBAB $1 / 3$, Sarmatian s.s., Barajevo-1, 15-20 m, n paratype IGOTBAB1/4, Sarmatian s.s., Barajevo-1, 20-25 m, 11 anterior view, $\mathbf{1 2}$ inner face, $\mathbf{1 3}$ dorsal view

pelvic fins elongate, pectoral-fin length measuring about $27 \%$ of SL; anterior end of the subopercle with distinct hook; postmaxillary process absent; otolith with rounded outline; sulcus short, deep, nearly uniformly oval in shape with poorly distinguished ostium and cauda and with low ostial lobe; subcaudal iugum long and mostly wide, below entire cauda and occasionally extending upwards into cauda.

Discussion The absence of a postmaxillary process and the broad gap between the first and second dorsal fins with four vacant interneural spaces characterizes Hesperichthys within the group of sand gobies/Pomatoschistus lineage. It also differs from the other genera of the group, except Economidichthys in having a low vertebral count. Other characters separating Hesperichthys from other genera of the sand gobies are the long pectoral fin, as well as the long base of the second dorsal fin. The otoliths exhibit a reduced morphology with a rounded outline and a sulcus, which is small and with a rather regular outline as compared to the typical sole-shaped outline generally found in gobiid otoliths.

A character requiring some special comments is the dorsal pterygiophore formula, which seems to vary between either $3-3111 \ldots$ and $2-12111 \ldots$ or $3-12 \ldots$ This variation is primarily due to the variable position of the first pterygiophore of the first dorsal fin. In the case of the holotype of Hesperichthys reductus, the situation is complicated because of the dorsal-ventral compression with the fish exposed in dorsal view (Fig. 11a). This led to some distortion of the position of the third abdominal vertebra and its neural spine relative to the first dorsal-fin pterygiophore (Fig. 11b). As a result, the pattern would be 3-3111 or, alternatively, 2-12111, in both cases very unusual. The paratype lacks the posterior part of the skeleton, including most of the first dorsal fin even though the preserved portion shows the typical sand goby initial pattern $3-12 \ldots$ (Fig. 11e). 
a
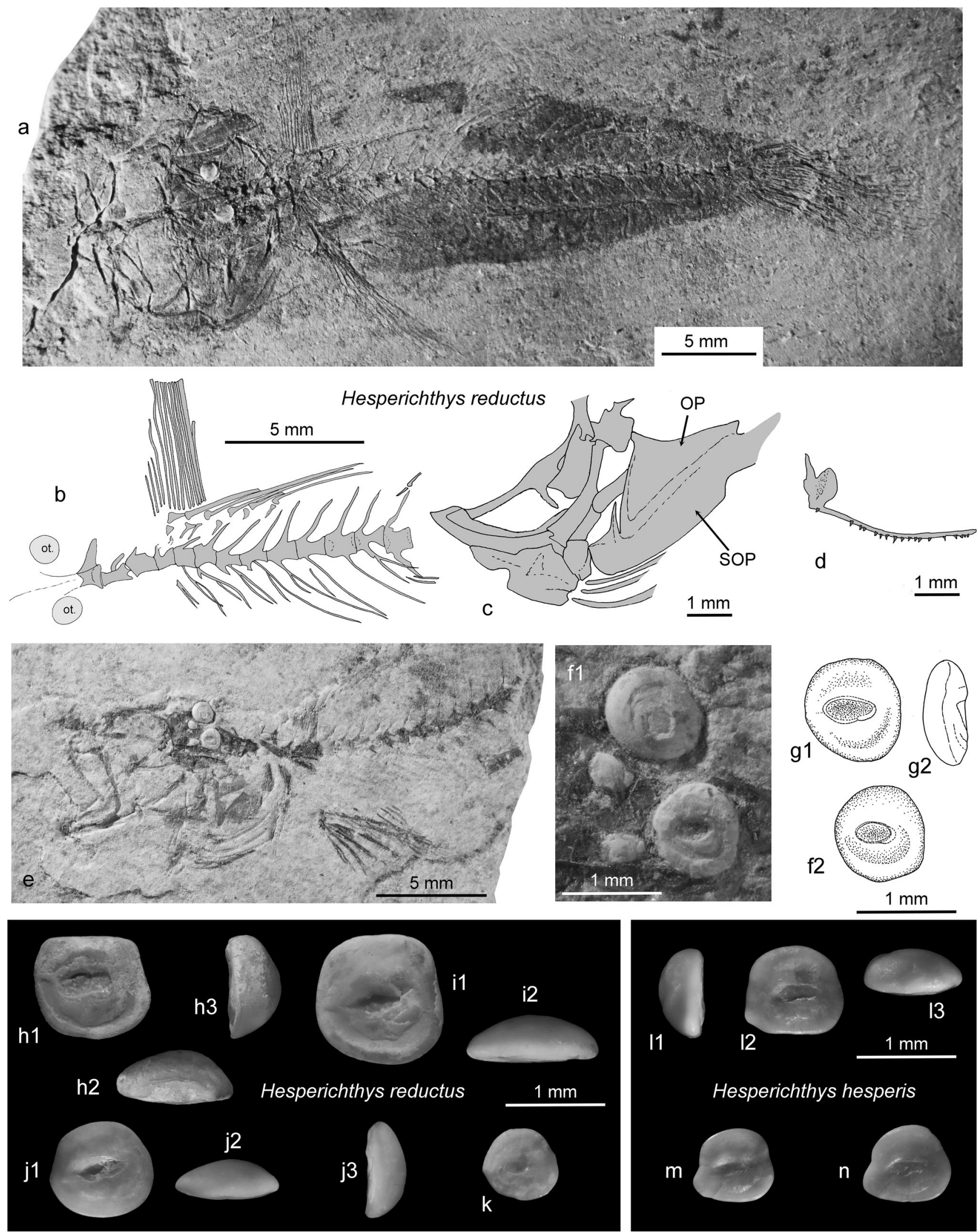
Schwarzhans et al. (2015) described the otolith-based species Hyrcanogobius hesperis from the late Volhynian (late Sarmatian s.s.) of Serbia and compared it to otoliths of the Recent $H$. bergi Iljin 1928, which is endemic to the Caspian Sea. It was considered as an indication of the presence of another endemic Ponto-Caspian gobiid to extend back in time until the Sarmatian. With the find of Hesperichthys reductus this species must be re-assigned to the same genus, as Hesperichthys hesperis. This shows that the otolith pattern with the long and widened subcaudal iugum in combination with the rounded otolith outline and the small sulcus, which was thought to be diagnostic for Hyrcanogobius, apparently has evolved more than once within sand gobies. Thus, we now interpret Hesperichthys as an example of the rapid evolution and diversification of gobies in the Paratethys after it became separated from the world oceans during Middle Miocene.

Species Two Sarmatian s.l. species : Hesperichthys reductus n.sp., based on a complete and an incomplete articulated skeleton with otoliths in situ from the early Sarmatian s.s. of Dolje, Croatia and isolated otoliths of the same species found in various locations of early to late Sarmatian s.l. age in Austria, Bulgaria and Romania; Hesperichthys hesperis (Schwarzhans, Bradić and Rundić 2015) from the late Sarmatian s.s. of Serbia.

Hesperichthys reductus Schwarzhans, Ahnelt, Carnevale and Japundžić n.sp.

(Figure 11a-k; Table 5)

?Gobius tenuis Weiler 1943._Paghida: pl. 2, fig. 1.

Holotype CNHM 149, a partially complete articulated skeleton with both saccular otoliths in situ, one of which extracted, from Dolje, Croatia, Sarmatian s.s. (Volhynian), $34.7 \mathrm{~mm}$ SL, Fig. 11a-c, g.

Paratype CNHM 271, an incomplete articulated skeleton preserved lacking the caudal portion of the axial skeleton, with both saccular and utricular otoliths in situ, the right otolith exposed from the inner face, from Dolje, Croatia, Sarmatian s.s. (Volhynian) Fig. 11d-f.

Referred material 16 isolated otoliths (Fig. 11h-k). UMG-X 8594, five otoliths from Galatin, Bulgaria, Volhynian to Bessarabian (early Sarmatian s.l.); UMG-X 8535, seven otoliths from Koshava well C-179, 181 m, Bulgaria, Bessarabian (middle Sarmatian s.1.); UMG-X 8595, two otoliths from Simeonovo B-7, Bulgaria, early Chersonian (late Sarmatian s.1.); SMF PO 91769, a single otolith from Wildon, Styria, Austria, early Sarmatian s.s.; SMF PO 91770, a single otolith from Gbely, well 358, 20.8-21.9 m, Slovakia, Sarmatian s.s..

Etymology From reductus (Latin) = secluded, sequestered, referring to the endemic nature of the fish in the Paratethys.
Diagnosis See genus diagnosis for skeletal characters. Otoliths: OL:OH $=0.95-1.05$; outline rounded with smooth rims; inner face flat; outer face strongly convex; sulcus very small, deepened, very little inclined; $\mathrm{OL}: \mathrm{SuL}=2.0-2.3$; ostium not discernable from cauda; moderately broad subcaudal iugum extending below entire cauda and around caudal tip.

Description Counts and measurements are reported in Table 5.

Neurocranium The specimen in Fig. 11a has a dorsoventrally compressed skull. The two frontals occupy most of the skull roof; anteriorly, the narrow frontals are slightly forked and articulate with the posterior part of the mesethmoid. The lateral ethmoid forms the anterior border of the orbit and has a large base and extends laterally into a narrow process. The parasphenoid extends anteriorly through the orbit. The sphenotic, posteriorly followed by the pterotic, is preserved ventral to the left frontal, forming part of the posterior border of the orbit.

Jaws The premaxilla has a pointed ascending process separated from the ovoid articular process by a distinct notch; the alveolar process is narrow; there is no postmaxillary process (Fig. 11d). The premaxillary teeth are conical and small. The maxilla is elongate and not distinctly expanded posteriorly. The dentary and anguloarticular are only partially visible.

Opercular series The opercle is triangular and the subopercle is distinctly hook shaped (Fig. 11c). The posterior end of the interopercle is seen immediately anterior to the subopercle, and is partially covered by the preopercle.

Suspensorium. Of the suspensorium, the hyomandibula (Fig. 11c), quadrate, symplectic and metapterygoid are clearly recognizable. The palatine has a T-shaped articular head.

Hyoid and gill arches A triangular posterior ceratohyal and an indeterminate number of branchiostegal rays are recognizable (Fig. 11e).

Axial skeleton The vertebral column consists of 29 $(11+18)$ vertebrae (Fig. 11a). The neural and haemal spines are long, narrow and pointed, and originate on the anterior part of the centra except for the last six haemal spines anterior to the urostyle. Pleural ribs articulate with the vertebrae three to 11 , in many cases associated with epineurals.

Caudal skeleton The caudal skeleton is not preserved in the available specimens. The caudal fin is rounded. There are 17 principal caudal-fin rays. 
Table 5 Counts and measurements of Hesperichthys reductus n.gen. et sp. and comparison with the extant Hyrcanogobius bergi Iljin 1928 and the aggregated extant genus Knipowitschia (extant data after Miller 2004)

\begin{tabular}{|c|c|c|c|c|}
\hline & \multicolumn{2}{|c|}{ Hesperichthys n.gen. reductus n.sp. } & \multirow[t]{2}{*}{ Hyrcanogobius bergi } & \multirow[t]{2}{*}{ Knipowitschia spp. } \\
\hline & HT-CNHM 149 & PT-CNHM 271 & & \\
\hline SL (mm) & 34.7 & & $<37$ & $<50$ \\
\hline Otolith in situ & Yes & Yes & & \\
\hline \multicolumn{5}{|l|}{ Meristics } \\
\hline Precaudal vertebrae & 11 & 12 & ? & $11-12$ \\
\hline Total vertebrae & 29 & & $?$ & $30-33$ \\
\hline D 1 & VI & $\mathrm{V}+$ & VI (VI-VII) & VI (V-VII) \\
\hline D 2 & $\mathrm{I}+9$ & & $\mathrm{I}+7-9$ & $\mathrm{I}+6-9$ \\
\hline A & $\mathrm{I}+10$ & & $\mathrm{I}+7-9$ & $\mathrm{I}+7-10$ \\
\hline Pectoral & 14 & & $15-18$ & $15-19$ \\
\hline D1 last ray between NS & NS6-NS7 & & NS6-NS7 & NS6-NS7 \\
\hline Empty neural spines & NS7-NS11 & & NS7-NS9 & NS8-NS19 to NS7-NS10 \\
\hline D2 first PT between NS & NS11-NS12 & & NS9-NS10 & NS9-NS10 to NS10-NS11 \\
\hline Caudal principle & 17 & & & 15 \\
\hline $\begin{array}{l}\text { Dorsal pterygiophore } \\
\text { formula }\end{array}$ & $\begin{array}{l}3-311100001 \text { or } \\
2-1211100001\end{array}$ & $3-12 \ldots$ & 3-1221001 & $3-1221001$ to $3-12201001$ \\
\hline Anal PT1 opposite to & $\mathrm{D} 2 / \mathrm{I}$ & & $\mathrm{D} 2 / 3$ & $\mathrm{D} 2 / 3$ \\
\hline $\begin{array}{l}\text { Postmaxillary process on } \\
\text { PMX }\end{array}$ & $\mathrm{nv}$ & Absent & Absent & Absent \\
\hline EPU & $1 ?$ & & 1 & 1 \\
\hline $\mathrm{AP}$ & 2 & & $?$ & 2 \\
\hline SOP anterior-ventral shape & Hook-like & & Hook-like & Hook-like \\
\hline \multicolumn{5}{|l|}{ Scales } \\
\hline On head & Naked & & Naked & Naked \\
\hline On body & $\begin{array}{l}\text { Body at least from pelvic } \\
\text { base }\end{array}$ & & $\begin{array}{l}\text { Back and abdomen } \\
\text { naked }\end{array}$ & $\begin{array}{l}\text { Predorsal and anterior back } \\
\text { naked }\end{array}$ \\
\hline Type & Mostly cycloid & & Ctenoid & Ctenoid \\
\hline Scales along lateral line & $31+$ & & $23-31$ & $30-33$ \\
\hline Scale size $(\mathrm{mm})$ & $\sim 1.0$ & & & \\
\hline \multicolumn{5}{|l|}{ Morphometrics (\% of SL) } \\
\hline Head length & 29.3 & & $26-32$ & $23.5-29$ \\
\hline Max. body height & $\mathrm{nm}$ & & $16.5-21$ & $17.5-24$ \\
\hline Orbit diameter & $\mathrm{nm}$ & $(7.4)$ & $6-7$ & $6.5-7.5$ \\
\hline D1 length & 12.3 & & & \\
\hline A length & $\mathrm{nm}$ & & & \\
\hline $\mathrm{PL}=$ pectoral length & 27.4 & & & $16-22$ \\
\hline Predorsal to D1 & 34.9 & & $34-39.5$ & $34.5-40$ \\
\hline Predorsal to D2 & 58.0 & & $52.5-55$ & $52.0-60.5$ \\
\hline Preanal & 60.0 & & $54-57.5$ & $55.5-65$ \\
\hline Base of D1 & 9.7 & & $8.5-10.5$ & $7-11$ \\
\hline Base of D2 & 27.1 & & $13.5-18.5$ & $13-18$ \\
\hline Base of A & $24.0(?)$ & & $12.5-15.5$ & $12.5-16$ \\
\hline Distance of D1 to D2 & 6.1 & & & $6.5-13$ \\
\hline
\end{tabular}


Median fins Two dorsal fins and a single anal fin are clearly recognizable. There is a distinct and long gap between both dorsal fins (Fig. 11b). The first dorsal fin contains six spines and originates above the third vertebra and terminates dorsal to the seventh vertebra. The second dorsal fin originates above the 11th vertebra (Fig. 11b). The anal fin consists of a single spine plus ten rays; it is characterized by two prehaemal pterygiophores, starting immediately ventral to the origin of the second dorsal fin (Fig. 11b). Four vacant interneural spaces are present between the seventh and tenth vertebrae.

Paired fins and girdles The pelvic fins are very long (Fig. 11a), with the longest fin rays extending posteriorly to the origin of the anal fin. In both specimens, six fin elements are recognizable. In the second specimen (Fig. 11e), the spine of the left pelvic fin is not visible but the five fin rays plus the fifth fin ray of the right side. Because the fin rays increase in length towards the center of the pelvic disc, the posterior margin of it is obviously rounded, at least not emarginated. Part of the right pectoral fin is preserved in the specimen of Fig. 11a. It contains 14 rays and very long, about $27 \%$ of SL. The supracleithrum is elongate with rounded ends immediately anterior to the supratemporal.

Otolith (sagitta) The otoliths are compressed and thick, reaching a length of slightly more than $1 \mathrm{~mm}$. $\mathrm{OL}: \mathrm{OT}=2.0-2.7$. The outline is regularly rounded without prominent angles, but sometimes with rounded pre- and postdorsal angles while the dorsal rim in between is nearly flat. All rims are smooth and show no incisions on the anterior or posterior rims.

The inner face is flat. The sulcus is small, short, moderately narrow, deep, and centrally positioned. The sulcus inclination is not measurable. The ostium is only slightly wider than cauda. There is a long, moderately wide subcaudal iugum below the entire cauda, which turns upward behind the cauda, and is often dorsally expanded to partly cover the cauda. There is no recognizable dorsal depression. The ventral furrow is wide, distinct, and runs moderately far from the ventral rim of the otolith. The outer face is distinctly convex and smooth.

Discussion Otoliths of Hesperichthys reductus differ from other subcircular gobiid otoliths occurring in the Sarmatian, including Aphia macrophthalma, Benthophilus? ovisulcus, Pomatoschistus bunyatovi and from the Tarkhanian/Tshokrakian Gobiusculus rotundus in having a deep sulcus and a long and dorsally expanded subcaudal iugum. It resembles $H$. hesperis (Schwarzhans, Bradić and Rundić 2015) from the Sarmatian of Serbia, from which it differs in having a more compressed and rounded outline (OL:OH $=0.95-1.05$ vs $1.05-1.15)$, deeply curved ventral rim (vs somewhat flattened) and long and dorsally expanded subcaudal iugum (vs short and indistinct and not dorsally expanded). Otolith specimens of $H$. hesperis are figured herein for comparative purposes (Fig. 111-n).

Genus Knipowitschia Iljin 1927

Knipowitschia bulgarica Schwarzhans, Bradić and Bratishko n.sp.

(Figure 10g-h)

Holotype UMG-X 8596, an otolith from Simeonovo B-7, Bulgaria, early Chersonian (late Sarmatian s.1.) (Fig. 10g).

Paratypes UMG-X 8597, three otoliths, same data as holotype (Fig. 10h).

Etymology Referring to Bulgaria.

Diagnosis OL:OH = 1.0. Broad dorsal rim, with distinct postdorsal angle instead of projection. Preventral angle broadly rounded, reduced, projecting less than obtuse predorsal angle. Very broad, rounded, and markedly expanded postventral angle. Sulcus wide, deep, inclined at $15^{\circ}-20^{\circ}$. OL:SuL $=1.6-2.2$. Indistinct, narrow subcaudal iugum.

Description The otoliths are small, high bodied, reaching up to about $0.85 \mathrm{~mm}$ in length (holotype $0.85 \mathrm{~mm}$ ); $\mathrm{OH}: \mathrm{OT}$ about 3 . The outline of the otolith is approximately trapezoidal. The dorsal rim is broad, straight or slightly curved, highest at the obtuse postdorsal angle. The predorsal angle is slightly depressed, obtuse or rounded, and there is no or only an incipient postdorsal projection. The ventral rim is flat, anteriorly curving into a broad preventral angle. The anterior rim is nearly vertical, but broadly rounded with a preventral angle set slightly backwards. The posterior rim is inclined towards dorsal at an angle of $65^{\circ}$ $75^{\circ}$, and is straight or with a faint concavity above the level of the cauda. There is a very broad, rounded, and distinctly projecting postventral angle.

The inner face is flat. The sulcus is moderately long, wide, deepened, inclined at about $15^{\circ}-20^{\circ}$. It is positioned slightly supramedian, with a narrow, rather indistinct subcaudal iugum. $\mathrm{CoL}: \mathrm{CoH} \max$ (holotype) equals 2.0, CoL: $\mathrm{CoH}$ min (holotype) equals 5 . The ostium shows a low to moderate lobe. The sulcus is sole-shaped in the holotype. The dorsal field is high and with an indistinct depression. The ventral field shows a broad ventral furrow relatively close to the ventral rim of the otolith and curving through the postventral expansion. The outer face is moderately convex and smooth.

Discussion The most striking character of Knipowitschia bulgarica is the nearly trapezoid outline with the broad postventral expansion and the reduced preventral angle. The development of the preventral angle in combination with the wide, sole-shaped sulcus distinguishes it from 
other small Sarmatian gobiid otoliths such as Protobenthophilus squamatus or Economidichthys altidorsalis or E. triangularis. Knipowitschia suavis is widely distributed in the late Badenian and early Sarmatian of the Paratethys and one of the very few species also known from the time equivalent SE-Mediterranean (Schwarzhans 2014; Bratishko et al. 2015). Knipowitschia bulgarica differs from $K$. suavis in the narrower postdorsal region, the reduced preventral region and the indistinct subcaudal iugum (vs long distinct subcaudal iugum extending towards the rear rim of the cauda).

Knipowitschia bulgarica is only known from the early late Sarmatian (early Chersonian). Within the genus Knipowitschia, it clearly resembles K. panizzae (Verga 1841) (see Schwarzhans et al. 2015 for figures), from which it differs in having a broader sulcus and the lack of an angle at the posterior rim at about the level of the cauda.

\section{Genus Pomatoschistus Gill 1864}

Pomatoschistus bunyatovi Bratishko, Schwarzhans and Reichenbacher 2015

(Figure 10j, k)

1992 "genus Gobiidarum” sp. 1.-Radwanska: pl. 35, figs. 1-2, text-fig. 146.

2015 Pomatoschistus bunyatovi Bratishko, Schwarzhans and Reichenbacher.-Bratishko, Schwarzhans, Reichenbacher, Vernihorova and Ćorić: figs. 10.13-10.17.

2015 Pomatoschistus bunyatovi Bratishko, Schwarzhans and Reichenbacher 2015.-Schwarzhans, Bradić and Rundić: figs. 7.14-7.16; (see there for further synonymies).

Material SMF PO 91771, a single otolith from well Kostel1, 398.6-405.6 m, Czech Republic, Podivín, late Sarmatian s.s. (Fig. 10j).

Discussion Pomatoschistus bunyatovi was originally described from the Konkian of Kazakhstan and was widely distributed throughout the Central and Eastern Paratethys during the late Badenian and Sarmatian, and possibly also during the early Badenian. It is clearly defined by the otolith outline being dorsally wider than ventrally and characterized by a steeply inclined sulcus $\left(15^{\circ}-25^{\circ}\right)$ with a much wider ostium than cauda. A specimen from Serbia (Fig. 10k; see Schwarzhans et al. 2015) is figured for comparative purposes.

\section{The cradle of the Ponto-Caspian gobies}

\section{The data base and its assessment}

The Gobiidae are the dominant and most diverse group of teleosts in the Sarmatian otolith record of the Paratethys (e.g., Weiler 1943, 1949, 1950; Pobedina 1954, 1956; Suzin 1968; Brzobohaty and Stancu 1974; Strashimirov 1984, 1985a, b; Djafarova 2006; Bratishko et al. 2015; Schwarzhans et al. 2015). Although they seem to be less common in the Sarmatian skeletal record (Steindachner 1860; Kramberger 1882; Carnevale et al. 2006), this review demonstrates that they are highly diverse and still relatively common. Such a discrepancy in abundance could be related to the fragile nature and small size of goby fish bodies, two factors that might prevent the fossilization of articulated skeletons, while conversely their role as small preys of larger fish would support their abundance in the otolith record.

The late Badenian and Sarmatian gobiid records of the Paratethys, therefore, consist of 15 otolith-based and nine skeleton-based species of which at least two documented herein are currently not recorded as isolated otoliths. This results in an overall account of at least 17 gobiid species regarded herein as valid. This already impressive list is still incomplete, primarily because of a large collection of middle Sarmatian otoliths from the Crimea awaiting description (by Bratishko and Schwarzhans), which contains numerous further gobiid representatives. Moreover, the material described by Djafarova, Pobedina and Suzin certainly contains several additional nominal gobiid species but is currently not available for review, which would be necessary for a comprehensive evaluation of these relevant data (see also extensive discussion of the situation in Bratishko et al. 2015). Suzin's publication (1968) unfortunately does not fulfill the rules of the ICZN, article 13.1.1, and consequently the taxa reported therein cannot be used. The material described by Weiler was reviewed in Bratishko et al. (2015). As pointed out above, only a portion of the mostly unpublished material collected by Strashimirov was available for review, even if it improves significantly our assessment. With these caveats in mind, the actual Sarmatian gobiid community in the Paratethys might have been about twice as diverse as currently recognized.

The spatial distribution of all these species, however, is remarkably variable. The four Sarmatian localities recording articulated gobiid skeletons have not yielded a single common species among any of them. Of the two localities studied herein, Dolje is the richest with four species while Belgrade added a single specimen belonging to a fifth species. Although otoliths are generally more common in the studied localities, we have not observed more than five different species in any of the Bulgarian, Romanian or Austrian localities of Sarmatian age. There were also five gobiid species among the nearly 2000 specimens described by Bratishko et al. (2015) from the slightly earlier Konkian of Kazakhstan, and six gobiid species have been recorded from the Konkian to early Sarmatian of Serbia (Schwarzhans et al. 2015). The 
unpublished collection from the middle Sarmatian s.l. of the Crimea appears to be the most diverse as far as gobiid otoliths are concerned with possibly up to 12 species. There are several widely spread otolith-based species such as Economidichthys triangularis, Hesperichthys reductus, Pomatoschistus bunyatovi or Proterorhinus vasilievae, but others have so far only been found in a single locality, i.e., Benthophilus? ovisulcus, Economidichthys altidorsalis and Hesperichthys hesperis. This indicates that the gobiid species flock in the Sarmatian included more generalized and widely distributed species and others which probably were adapted to more restricted environments or geographic areas, similar to the extant Ponto-Caspian gobies (Miller 2003, 2004). Miller lists 34 goby species from the Caspian Sea and its tributaries, and 45 when including also the Black Sea and its tributaries, of which 17 species belong to the endemic tadpole goby genus Benthophilus (mostly in the Caspian). It appears that the Sarmatian Sea may have been only slightly less species rich than the present Caspian Sea, but the wealth of goby diversity captured so far spreads over a time interval of about 5 myr from Konkian to late Sarmatian s.l. There are clear indications of evolutionary lineages within certain groups, for instance Aphia, Knipowitschia and possibly also Ponticola and Benthophilus, indicating that some of the diversity observed has a stratigraphic component (Figs. 12, 13).

\section{The phylogenetic context}

Gobioid saccular otoliths are morphologically distinctive, easily recognizable for the sole-shaped sulcus located on the center of the inner face and the outline of the otolith, which ranges from quadrangular to nearly rectangular to almost triangular or rounded. However, taking into account that the Gobiidae is the most diverse marine teleost family, the diversification of the general aspect of the gobiid otoliths is constrained from a morphological point of view. Nolf (1985) claimed that "numerous fossil otolith-based species of gobiids have been described, but many are based on eroded specimens or atypical juveniles" and concluded that "combined with our (then) very poor knowledge of Recent gobiid otoliths, this results in a chaotic gobiid otolith paleontology". However, much progress has been achieved since, thanks among the others to the works of Brzobohaty et al. (2007), Nolf and Cappetta (1980), Nolf and Cavallo (1995), Reichenbacher (1988, 1998), Schwarzhans (2010, 2014) and Steurbaut (1984), resulting in a much more stable taxonomy of gobiid otoliths from the Neogene of the Atlanto-Mediterranean Basins of Europe, despite the problems of associating fossil gobiid otoliths with extant gobiid genera in large part caused by the potentially multiple homoplasies emerging in the shaping of the otolith morphology. The situation for post-early Badenian/Tarkhanian Paratethyan otoliths was still chaotic (as described by Nolf in 1985) until very recently, in large part due to the lack of knowledge of otoliths of Recent endemic Ponto-Caspian gobies, which became significantly resolved through the generous support of E. Vasilieva of ZMMGU (Moscow) to one of us (WS). The availability of an adequate otolith coverage of Recent Ponto-Caspian gobies had an immediate impact on the taxonomic works of Bratishko et al. (2015) and Schwarzhans et al. (2015) and revealed the presence of several Ponto-Caspian gobiid lineages back into the Konkian and Sarmatian s.l. of the Paratethys.

The finding of otoliths in situ in five different gobiid species from the Sarmatian of the Central Paratethys described herein represents an important test of the systematic hypotheses proposed based on isolated otoliths in these two publications, and it supports the hypotheses based on isolated otoliths, but also provides a much more complex and diverse picture. Our observations are consistent with the analyses of gobioid skeletons with otoliths in situ by Reichenbacher et al. (2007), Brzobohaty and Gaudant (2009), Gierl et al. (2013) and Gierl and Reichenbacher (2015). All of these works document the relevance of integrated studies of articulated skeletons and otoliths found in situ in providing an enhanced assessment of the phylogenetic position of fossil fishes, and, particularly, in this case, that of fossil gobies.

The Benthophilus lineage may be considered the main endemic Ponto-Caspian gobiid lineage and it is represented by articulated skeletons related to both the subgroups of the lineage, the neogobiin and benthophilin subgroups. Interestingly, both subgroups are represented by "primitive" extinct genera (i.e., †Proneogobius and †Protobenthophilus) considered to be the sister group to all extant members of their respective subgroups (Fig. 12). Proneogobius looks morphologically intermediate between the Atlanto-Mediterranean Gobius, which is known by otoliths since at least Early Miocene, and the basal extant member of the neogobiin subgroup, Neogobius. The intermediate position is best exemplified by the intermediate number of vertebrae with Gobius having 27-28 vertebrae, Neogobius 31-34 vertebrae and Proneogobius 29-31. Isolated otoliths do not provide a conclusive taxonomic information in this case and could have been interpreted as a species of Gobius because of the presence of a distinct subcaudal iugum or alternatively a species of Neogobius because of the shape of the dorsal rim. Protobenthophilus shares certain putative synapomorphies with modern benthophilin genera, i.e., the anterior end of the subopercle without hook, narrow first dorsal-fin base, which is shorter than the gap between the first and second dorsal fin, low number of precaudal vertebrae, low second dorsal- and anal-fin ray counts, and 


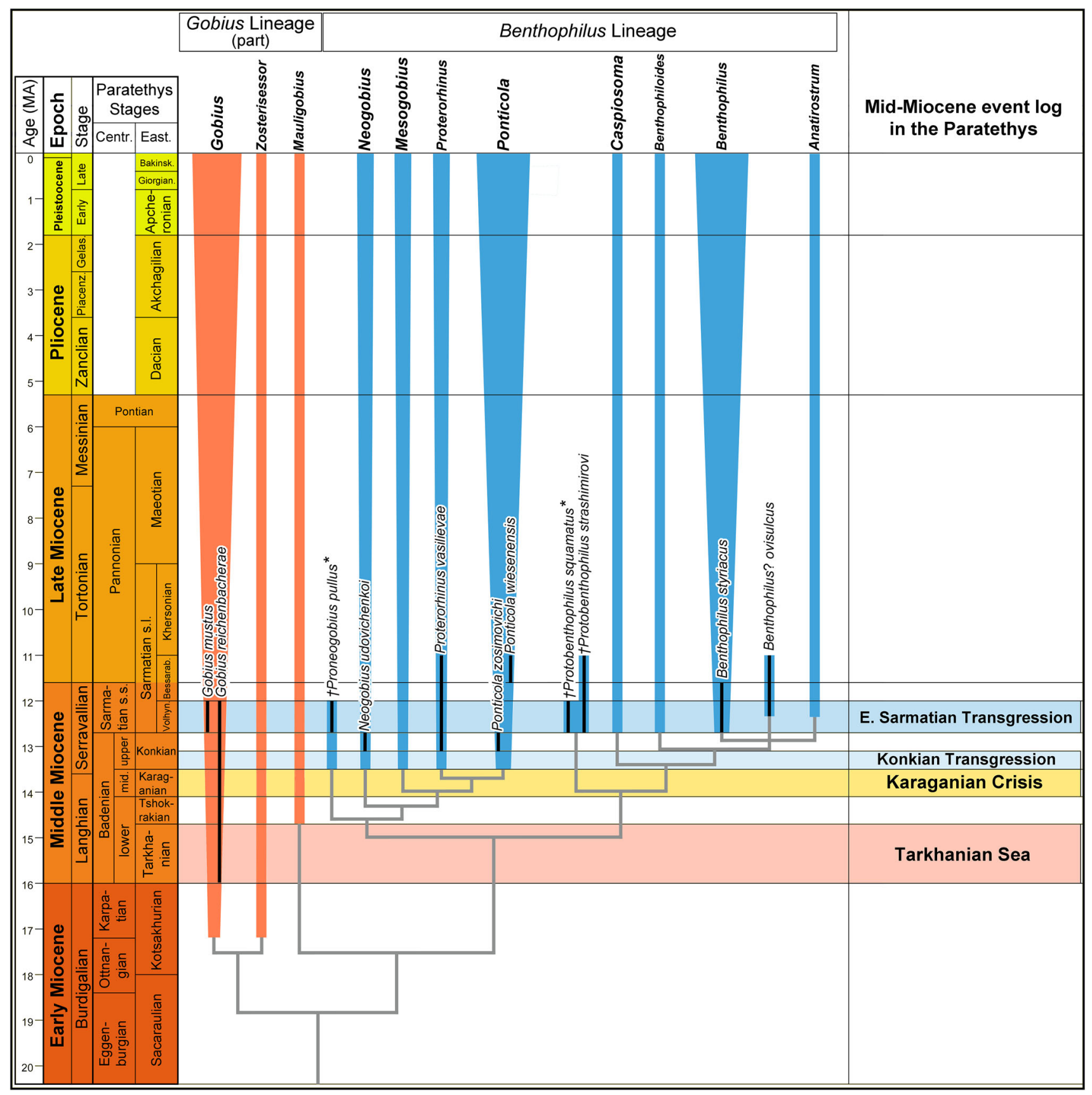

Fig. 12 Phylogenetic relationships of part of the Gobius lineage and the Benthophilus lineage with fossil species ranges included, based on Agorreta et al. (2013) and Neilson and Stepien (2009). Dichotomies

otolith pattern with a short, poorly structured sulcus and without subcaudal iugum and postdorsal projection. The absence of free dorsal pterygiophores and a rather continuous body squamation of unaltered ctenoid scales, however, are distinctly plesiomorphic characters and suggest that Protobenthophilus is close to the basal divergence of the 'bethophilin' subgroup. Both characters seem to suggest an origin of the Benthophilus lineage not long before the Sarmatian. The origin and diversification of the depicted represent minimum divergence times estimated based on fossil records. Entries annotated by asterisk denote articulated skeletons with otoliths in situ; others are based on otoliths

neogobiin and benthophilin subgroups are likely linked to the segregation of the Eastern Paratethys during Tshokrakian and Karaganian, even though the presence of some of the more modern lineages is already indicated by otoliths during Konkian times (Neogobius, Ponticola and Proterorhinus), and Sarmatian (Benthophilus). Benthophilus is characterized by a specialized otolith pattern already in the middle Sarmatian (Benthophilus? ovisulcus), which cannot be linked to any of the persistent 


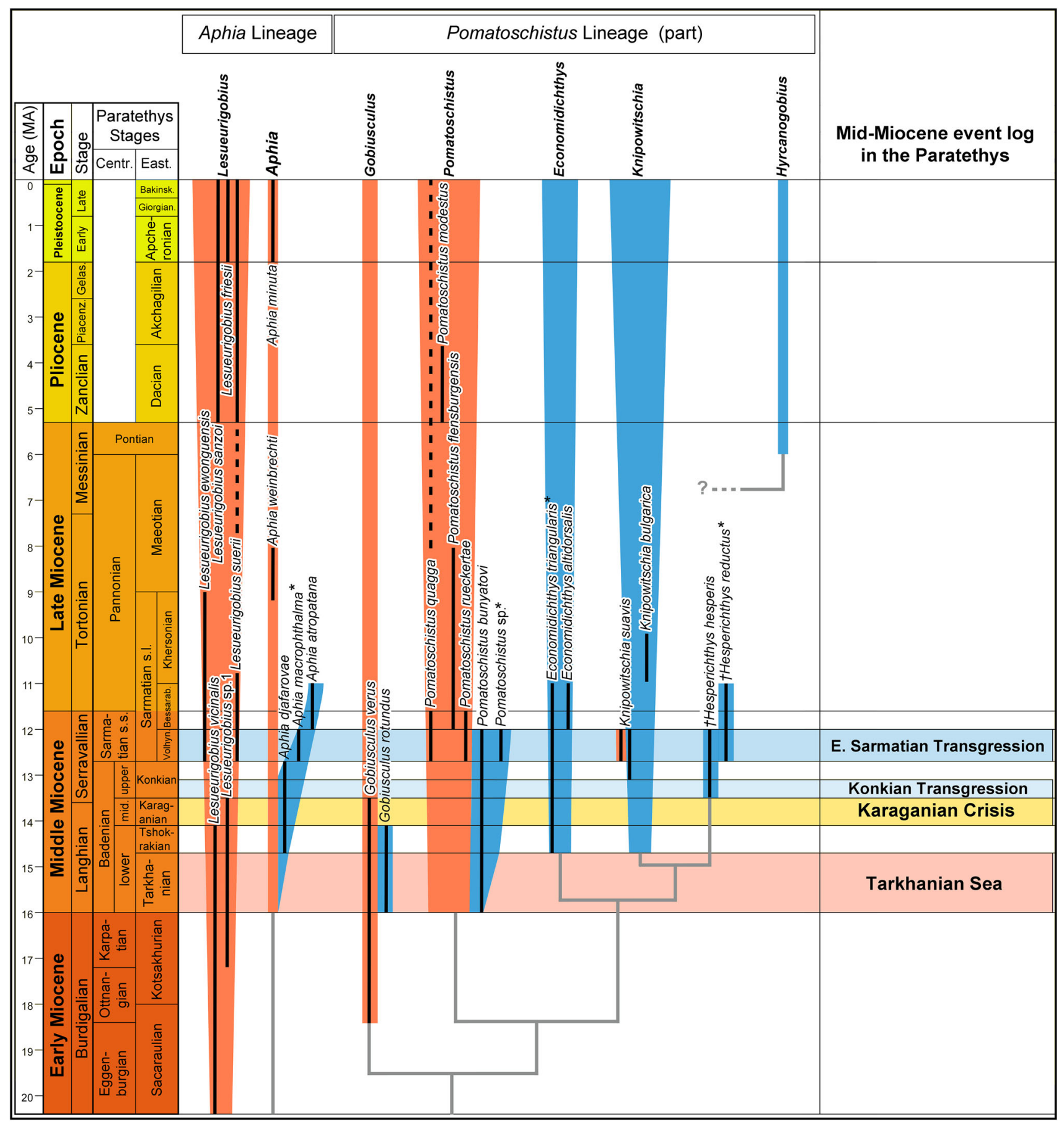

Fig. 13 Phylogenetic relationships of the Aphia lineage (Gobiinae) and part of the Pomatoschistus lineage (Gobionellinae) with fossil species ranges included, based on Agorreta et al. (2013). Dichotomies

benthophilin lineages from which otoliths are known; it may in fact represent an early specialized extinct offshot.

The other typical endemic Ponto-Caspian gobies are included in the large Pomatoschistus lineage (or sand gobies), which also contains Atlanto-Mediterranean members and freshwater species in Italy, the Balkans and Turkey. Pomatoschistus was related to the Gobionellidae (here depicted represent minimum divergence times estimated based on fossil records. Entries annotated by asterisk denote articulated skeletons with otoliths in situ; others are based on otoliths

in subfamilial ranking as Gobionellinae) by Thacker (2013) and, subsequently, placed in a much expanded $P o$ matoschistus lineage within the Gobionellinae by Agorreta et al. (2013), both implying a relationship with primarily Indo-Pacific gobies instead of Atlanto-Mediterranean ones. The record of otoliths of the Pomatoschistus lineage (sensu Agorreta et al. 2013) in Europe is well established since 
Early to early Middle Miocene and comprises primarily the genera Deltentosteus, Gobiusculus and Pomatoschistus. This early occurrence would indicate a putative migration from an Indo-Pacific stock at a time when there was still ample shallow water connectivity through the ArabianPersian gap. Genera such as Deltentosteus and Pomatoschistus have quite distinctive otoliths, which can be found in shallow water sediments of the Early and Middle Miocene of nearly all European basins. The endemic Ponto-Caspian (and freshwater balkanid) gobies appeared in the Tshokrakian to Sarmatian of the Paratethys, i.e., during the initial period of the break-away of the Paratethys during the Middle Miocene. Economidichthys was the first to appear and is now confirmed by an articulated skeleton from Dolje assigned to E. triangularis, a species originally described based on otoliths (Fig. 13). In addition to certain characters diagnostic of the Pomatoschistus lineage like the lack of a postmaxillary process, dorsal pterygiophore formula starting with 3-1231 and characterized by three free interneural spaces between first and second dorsal fins, it shares a reduced number of vertebrae (29) with Economidichthys (29-31), while other genera of the sand gobies have 30-33 vertebrae. Schwarzhans (2010) associated Economidichthys triangularis otoliths with the dwarf reef goby genus Trimma because of the overall similar outline of the otolith and because Recent Economidichthys otoliths were then unknown, highlighting the risk and danger of misleading homoplasies in goby otoliths. Nowadays, Economidichthys is known from two endemic freshwater species in the rivers and lakes of the Balkans. The fossil finds indicate that the Recent freshwater endemism clearly descended from a former marginal marine to brackish stock. The subsequent endemic sand goby genera to appear are Knipowitschia and the extinct $†$ Hesperichthys (Fig. 13). Both these genera were formerly recorded by isolated otoliths only, and Hesperichthys was then considered to represent a species of a lineage leading to the extant Caspian endemic Hyrcanogobius (Schwarzhans et al. 2015) because of the peculiar reduced sulcus morphology and the widened subcaudal iugum extending onto the cauda, which the fossil species Hesperichthys hesperis shares with the Recent Hyrcanogobius bergi. A second species of that group is described here based on articulated skeletons with otoliths in situ (Hesperichthys reductus) leading to the recognition of a separate fossil sand goby genus, named Hesperichthys. The high number of second dorsal-fin and anal-fin rays, as well as the wide gap between the two dorsal fins with four free interneural spaces, defines an apomorphic character state that is not matched by any of the extant sand gobies. This shows that the highly specialized otolith pattern, which was considered as diagnostic for Hyrcanogobius, apparently has evolved independently within sand gobies. Hyrcanogobius can be considered as a more recent specialized taxon of the Knipowitschia stock in the Caspian Sea and Hesperichthys may represent an extinct early specialized branch. In conclusion, the fossil 'sand goby' records show that the explosive radiation of Paratethyan endemics occurred at about the same time in the Pomatoschistus and Benthophilus lineages, possibily triggered by the same mechanisms (see below). Moreover, it shows that, like in the Benthophilus lineage, the early radiation does not match up entirely with the extant Ponto-Caspian endemic fishes, but instead that several extinct branches appeared in the course of the seemingly complex and rapid evolution of these fishes.

A further emergence of endemics is documented in the Aphia lineage during the Tshokrakian to Sarmatian of the Paratethys. The Aphia lineage was defined by Agorreta et al. (2013) to contain the paedomorphic genus Aphia and the deeper water genus Lesueurigobius. Both are European Atlanto-Mediterranean genera not present in the PontoCaspian Basin today. Otoliths of Lesueurigobius are common throughout the Miocene of the Atlanto-Mediterranean basins of Europe with a variety of species appearing since the Late Oligocene (Nolf and Brzobohaty 1994). The earliest verified records of the genus Aphia consist of otoliths of A. djafarovae Bratishko, Schwarzhans and Reichenbacher 2015 from the Konkian of Kazakhstan (Bratishko et al. 2015) and the late early and middle Badenian (Tshokrakian to Karaganian equivalents) of Poland recorded by Radwanska (1992) as "genus Gobiidarum” sp. 3. It seems to form the basis of a lineage also including $A$. macrophthalma, described herein based on an articulated skeleton with otoliths in situ and that appears to terminate with the middle Sarmatian A. atropatana (Djafarova 2006) in the Eastern Paratethys (Fig. 13). The earliest known representative of the genus within its classical AtlantoMediterranean area of distribution is A. weinbrechti Schwarzhans 2010 from the Late Miocene of the North Sea Basin. Aphia macrophthalma differs from the Recent $A$. minuta in having a lower number of second dorsal- and anal-fin rays, and the dorsal pterygiophore insertion pattern with two vacant interneural spaces anterior to the second dorsal fin and an ossified sixth pterygiophore. We, therefore, consider the Aphia djafarovae-macrophthalma-atropatana lineage as a branch-off from a largely unknown lineage linked to the Recent A. minuta, and as an example of a further endemic evolution of a gobiid group during the early phases of geographic separation of the Paratethys during the Middle Miocene.

\section{The biogeographical context}

The comparison with fish faunas from outside the Paratethys is somewhat hampered by the fact that coeval otolith 

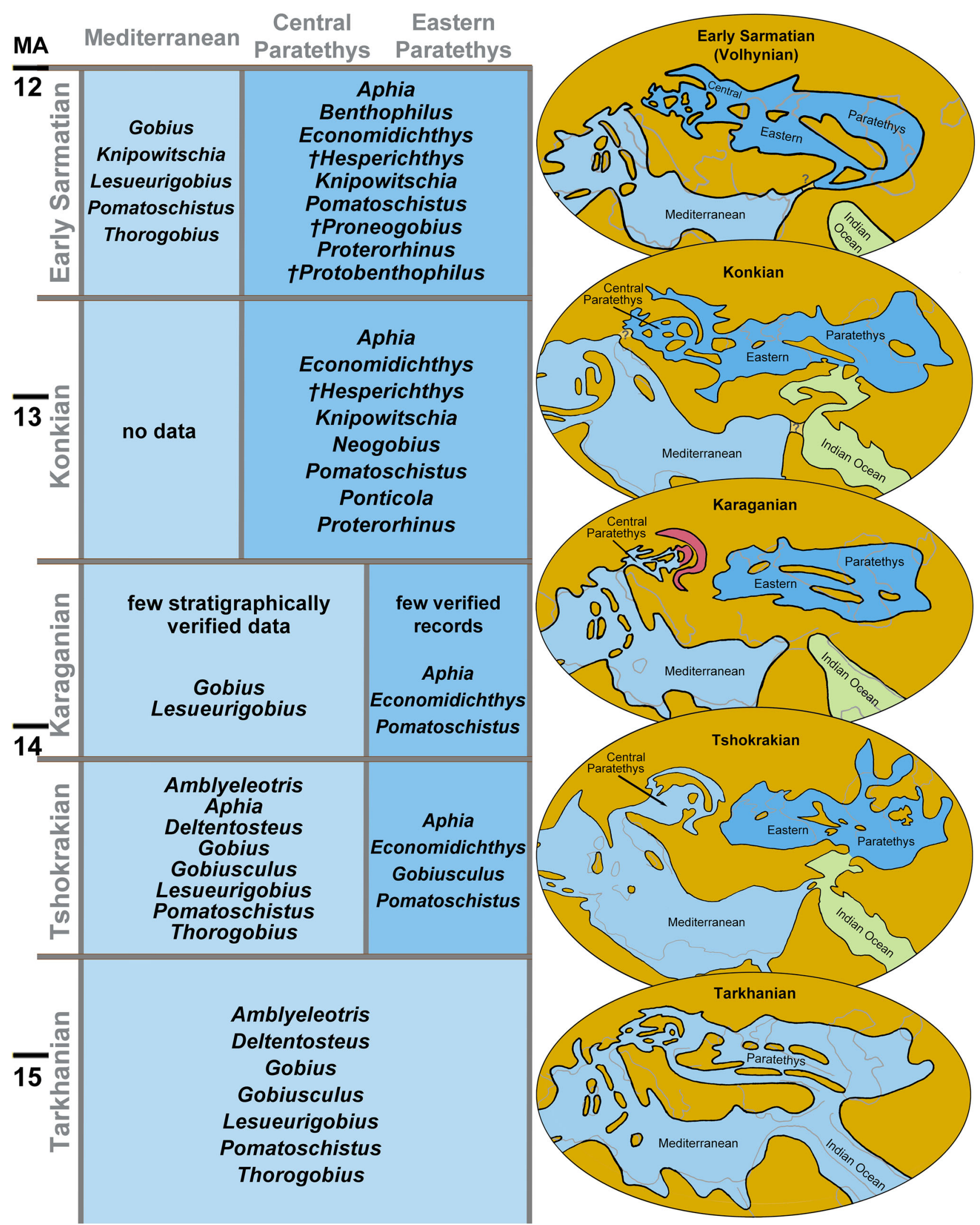
4Fig. 14 Paleogeographic event chart of the Paratethys and adjacent seas during the Middle Miocene based on Rögl (1999) and Popov et al. (2004), and development of the gobiid faunal composition, primarily based on otoliths, in the Mediterranean (light blue) and Paratethyan (dark blue) paleobioprovinces. Light green denotes a putative Indian Ocean paleobioprovince (no otoliths known from this time interval); dark pink represents evaporitic sedimentation in secluded basins of the Central Paratethys during middle Badenian (Karaganian equivalent). Alternative sea connections during Konkian and early Sarmatian are annotated with a '?' and are briefly discussed in the text

(and fish) assemblages in the Mediterranean reflect deep water environments largely devoid of gobies, except for the rich near shore otolith-based faunas from Catalunya, Spain (Hoedemakers and Battlori 2005) and the Karaman Basin in Turkey (Schwarzhans 2014). Other otolith assemblages suitable for correlation are further away in the AtlantoMediterranean area, including the Aquitaine Basin of France (Steurbaut 1984) or the North Sea Basin (Schwarzhans 2010) and are subject to more or less pronounced geographical and/or climatic variations. Another aspect of uncertainty is related to the necessity of comprehensive revisionary studies of Miocene otolith assemblages of the Eastern Paratethys (see above and Bratishko et al. 2015). Only a few records contained in the publications by Pobedina, Strashimirov and Djafarova (see above) can be verified and are useful at this stage. Finally, the stratigraphic resolution of many of the otolith assemblages from outside of the Eastern Paratethys is less detailed and not suitable for an accurate comparison, either because such high resolution could not be achieved or because detailed stratigraphic notes were not recorded during the otolith sampling. In a few instances, the sampled locations can be re-calibrated using modern biostratigraphic works, particularly in the Central Paratethys (see Bratishko et al. 2015). The provenance and relevance of the underlying data for the biogeographical evaluation are discussed for each of the time slices as follows. The paleogeographic reconstructions and selection of time slices are based on Rögl (1999) and Popov et al. (2004) with minor modifications discussed in the text. The Eastern Paratethyan stratigraphic nomenclature is used for guidance because of the key role of this basin in the development of the Ponto-Caspian Sea.

The Tarkhanian Sea (Early Langhian = early lower Badenian) represents the last stage of a wide and unrestricted marine connectivity between the Mediterranean, Paratethys and Indian Ocean (Rögl 1999) (Figs. 12, 13, 14). Short intervals of seclusion of the Eastern Paratethys occurred already during the Kotsakhurian (Late Burdigalian, =part of Ottnangian and Karpatian) (Vakarcs et al. 1998, Rögl 1999). Bannikov (2010) listed skeletal records from the preceeding Sakaraulian, which does not contain gobies, and there are no fossil otolith data from the
Sakarulian or Kotsakhurian known from the Eastern Paratethys. Tarkhanian otoliths have been recorded by Pobedina (1954), Strashimirov (1972) and Djafarova (2006) from the Eastern Paratethys. They are difficult to interpret without review, but seem to contain many species also known from the Central Paratethys, including several gobies of the genera Gobius, Gobiusculus and Pomatoschistus. Otoliths described from the Central Paratethys usually lack stratigraphic detail (except for Radwanska 1992) having been recorded from early Badenian and, therefore, not distinguishable as Tarkhanian or Tshokrakian. The main references from the Central Paratethys are those of Schubert (1906), Nolf (1981), Brzobohaty et al. (2007), Nolf and Brzobohaty (2009) and (for the Gobiidae) Schwarzhans (2010). A large otolith-based fauna from Spain described by Hoedemakers and Battlori (2005) ranges stratigraphically from Late Burdigalian to Langhian. It seems that these faunas show much similarity supporting an unrestricted faunal exchange across the area at the time. Gobies are represented by the ubiquitous genera Deltentosteus, Gobius, Lesueurigobius, Pomatoschistus and Thorogobius (as Priolepis in Brzobohaty et al. 2007). A potential Indo-Pacific element is indicated by otoliths interpreted as representing Amblyeleotris in Schwarzhans (2010) (as "genus Gobiidarum" sp. 2 in Radwanska (1992), ?Yongeichthys in Hoedemakers and Battlori (2005) and as Oxyurichthys in Brzobohaty et al. 2007).

Popov et al. (2004) showed the Eastern Paratethys as separated from the Central Paratethys in the subsequent Tshokrakian stage (Middle Langhian $=$ lower Badenian) (Fig. 14). The otolith knowledge from the Eastern Paratethys is poor from that time interval. Data contained in Strashimirov (1980) and Djafarova (2006) are in need of a substantial review. However, they seem to indicate the presence of some "new" goby taxa, including Economidichthys triangularis. Aphia djafarovae probably occurred in both the Central and Eastern Paratethys (as "genus Gobiidarum" sp. 3 in Radwanska (1992)).

The Karaganian Crisis (Late Langhian $=$ middle Badenian) represents a pivotal event in the paleogeographic evolution of the Eastern Paratethys, which became completely separated from the adjacent oceanic systems at that time (Fig. 14). A reduction of water salinity occurred across the Eastern Paratethys. The reduced water circulation led to the establishment of a hydro-sulphidic zone in the deeper parts of the sea and pushed the fish fauna into the upper, brackish layers of the pelagic zone (Mikerina and Pinchuk 2014; Baykina and Schwarzhans 2016). In the words of Kovác et al. (2007), "no Tshokrakian genus survived the Karaganian crisis". Fish skeletons and otoliths are rare from the Karaganian. Baykina and Schwarzhans (2016) mention a clupeid, an atherinid, a mugilid, and a bothid but no goby. Strashimirov 1981 figured a few 
Karaganian otoliths; among them possibly is an atherinid (as Trigla miocenica Pobedina 1954 and Clupea suzini Pobedina 1954), a bothid ("Rhombus" corius Chalilov 1946) and a gobiid (as Hymenocephalus quadratus Strashimirov 1981). Djafarova (2006) also figured bothid and gobiid otoliths from the Karaganian of Azerbaijan. Among several specimens that cannot be evaluated without a detailed revision, she figured otoliths which appear to be typical representatives of Economidichthys triangularis (which possibly was a Tshokrakian survivor). In the Central Paratethys, the Karaganian roughly corresponds to the middle Badenian salinity crisis (Kovác et al. 2007). Only the Pannonian Basin remained under normal marine conditions connected to the Mediterranean (Rögl 1999) via a western connection. Detailed and verified otolith data are scarce for this time interval in the Central Paratethys (see discussion in Bratishko et al. 2015), but as far as known they do not seem to differ fundamentally from the early Badenian associations. As far as the gobiids are concerned, at least Gobius and Lesueurigobius were present in the Central Paratethys while no such records are confirmed from the Eastern Paratethys. Despite all the obvious caveats in the reliability of the available otolith data, we interpret the sparse information at hand as an indication of a first establishment of a new, biogeographically separated (non Atlanto-Mediterranean) fish fauna in the Eastern Paratethys and we speculate that it might represent the first pulse for the evolution of the endemic Ponto-Caspian gobies.

The Konkian (Early Serravallian $=$ upper Badenian) begins with a basin-wide transgression across the entire Paratethys. An interchange of the fish fauna is clearly evident from the known otolith assemblages (Bratishko et al. 2015). The connections of the Paratethys with the adjacent oceans have been extensively discussed by Rögl (1999), Popov et al. (2004) and Bratishko et al. (2015). Options include connections to the Mediterranean in the west and to the Indian Ocean and the SE Mediterranean through a southern seaway (Fig. 14). From a teleost perspective, the correlation with the faunas of the adjacent seas is limited with the Mediterranean and totally absent with the Indian Ocean. In the Mediterranean, a rich shallow water otolith-based fauna has been recently described from the Karaman Basin in SE Turkey, not far from one of the inferred connecting seaway (Schwarzhans 2014). This Serravallian fauna is probably younger than late Badenian/ Konkian and rather equivalent to the early Sarmatian (Landau et al. 2013). In any case, it is rich in gobies and does not show any similarity with the Konkian otolith assemblages of the Eastern Paratethys in Kazakhstan (Bratishko et al. 2015), except for a single speciesKnipowitschia suavis. The same is true for the early Sarmatian (Late Serravallian) fish fauna of the Paratethys, being a time interval that was characterized by a renewed transgression throughout the Paratethys after a brief regressive phase during late Konkian. Two gobiid genera are recognized during this time interval from the Mediterranean and the Paratethys-Knipowitschia and Pomatoschistus. However, there is only one shared species (Knipowitschia suavis), while Pomatoschistus is represented with different species in either sea. The composition of the gobiid assemblage of the Karaman Basin seems to be inherited from the earlier Langhian/early Badenian Atlanto-Mediterranean fauna (Gobius, Lesueurigobius, Pomatoschistus and Throgobius)(Fig. 14). The Central and Eastern Paratethys, on the other hand, were populated by several gobiid genera which are related to the extant Ponto-Caspian lineages, which are not reported from lower Langhian deposits of the region and which are not found in the Mediterranean (except Knipowitschia and Pomatoschistus). These observations confirm a fundamental faunal turn-over from Tshokrakian to Konkian/early Sarmatian in the Paratethys and contradict in our view any postulated connections of the Central or Eastern Paratethys to the Mediterranean during the same time interval (see also Bratishko et al. 2015).

The link between the paleogeographic development of the region and the changes in the composition of the gobiid assemblage in the Central and Eastern Paratethys document that the Konkian/Sarmatian Sea acted as a cradle for the endemic evolution of modern Ponto-Caspian gobies. It pushes back the origin of these lineages of fishes to the earliest Miocene segregation events of the Paratethys, well before the assumed origination times usually discussed in many phylogenetic studies (Economidis and Miller 1990; Miller, 1990, 2003, 2004; Huyse et al. 2004; Neilson and Stepien 2009), being consistent with the results discussed by Thacker (2015). Not all the observed endemic lineages persisted until today, and much remains to understand about the structure and composition of gobiid assemblages in this basin before we start to properly decipher the evolution of this amazing group of fishes, certainly the most successful in the rapidly changing environments of the Ponto-Caspian Sea.

\section{Conclusions and outlook}

The present study reveals an unexpected richness of fossil gobiid diversity based on articulated skeletal remains. The presence of otoliths in situ in many of the specimens provides a tremendous opportunity to connect the contemporaneous otolith-based gobiid assemblage and adds new insight into an important phase of gobiid evolution in a dynamic basin. 
1. The otolith bearing articulated skeletons confirm the previous allocation of the isolated otoliths in general terms, but they also exhibit many additional characters that facilitate a much more detailed phylogenetic assessment of the combined data. The resulting phylogenetic picture is more complex than that which could be possibly restored based on isolated otoliths only. On the other hand, a large proportion of the isolated otolith finds of the region are now effectively calibrated, thereby leading to the recognition of a much wider diversity than the skeleton finds indicate. Finally, they provide a much more detailed insight into the spatial and chronological evolution of the taxa involved.

2. The skeleton and otolith-based data presented herein show that all major endemic Ponto-Caspian gobiid lineages were already present in the Paratethys during the early Sarmatian. This involves the two subgroups of the Benthophilus lineage (neogobiin and benthophilin subgroups) and genera of the Pomatoschistus lineage (Economidichthys, Knipowitschia and the extinct 'early endemic' Hesperichthys). The origin of the endemic Ponto-Caspian gobies, therefore, is older than previously considered in most ichthyological literature which had no paleontological data available at the time.

3. A rapid faunal turn-over of the Paratethyan gobiid assemblage is observed from an Atlanto-Mediterranean composition in the Langhian to a PontoCaspian composition in the Serravallian (Konkian and Sarmatian). This turn-over coincides with a major reorganization of the Ponto-Caspian Basin that transformed into a marginal inland sea with only rare transient connections to the world oceans and which was subject to dramatic and rapid environmental changes. These geological and ecological changes were favorable for the gobiids and apparently promoted the evolution and radiation of a broad endemic Ponto-Caspian stock.

In summary, we would like to promote additional studies of fish skeletons with otoliths in situ since we believe that linking of the two, hitherto mostly independent data sets will greatly contribute to our understanding of teleost evolution. It would also make otoliths a more useful tool through their calibration with additional characters necessary for a more comprehensive analysis of the fishes. We are aware of further articulated skeletons with otoliths in situ primarily from the Sarmatian of the Paratethys, and the study of these will become future volumes of our ongoing project. We are convinced that there will be many more of these opportunities awaiting discovery and description and we hope that our study will inspire colleagues to venture more into this field of paleoichthyological research.

Acknowledgments We thank Ms. E. Vasilieva (Moscow, ZMMGU) for making available to one of us (WS) a very comprehensive collection of Recent Ponto-Caspian gobies for otolith extraction, without which this study would have been impossible to perform. Ms. Vasilieva also took great care to make sure that all fishes were accurately identified from which otoliths were extracted. Further comparative extant otolith material was made available by J. Nielsen and P. Møller (Copenhagen, ZMUC). We are also most thankful to S. Strashimirov (Sofia), son of the late B. Strashimirov, and Ms. D. Sinnyovska (Sofia, UMG) for tracing material collected by B. Strashimirov in the 80's and for making it available for review. Alan Lord and Ms. C. Franz (Frankfurt/Main, SMF) kindly made available material collected by Weiler in the 40's and 50's. Ms. E. Koleva-Rekalova (Sofia, Bulgarian Academy of Sciences) kindly provided important geographical and stratigraphical information to many of the samples collected by B. Strashimirov. Finally, we would like to thank Ms. B. Reichenbacher and C. Gierl (Munich, LMU) for their constructive exchange of views during an early stage of our study. The research of GC was supported by grants (ex-60 \% 2014 and 2015) from the Università degli Studi di Torino. We thank C. Thacker (Los Angeles) and R. Brzobohaty (Brno) for their constructive criticism of our manuscript.

Open Access This article is distributed under the terms of the Creative Commons Attribution 4.0 International License (http://crea tivecommons.org/licenses/by/4.0/), which permits unrestricted use, distribution, and reproduction in any medium, provided you give appropriate credit to the original author(s) and the source, provide a link to the Creative Commons license, and indicate if changes were made.

\section{References}

Agoretta, A., San Mauro, D., Schliewen, U., Van Tassell, J. L., Kovaćić, M., Zardoya, R., \& Rüber, L. (2013). Molecular phylogenetics of Gobioidei and phylogenetic placement of European gobies. Molecular Phylogenetics and Evolution, 69, 619-633.

Ahnelt, H. (2003). The postcranial skeleton of the benthophiline gobiids Anatirostrum and Benthophilus (Teleostei: Gobiidae). Folia Zoologica, 52(2), 213-221.

Ahnelt, H., Abdoli, A., Naderi, M., \& Coad, B. W. (2000). Anatirostrum profundorum: a rare deep-water gobiid species from the Caspian Sea. Cybium, 24(2), 139-159.

Anđelković, J. (1969). Fosilne ribe iz donjeg sarmata teritorije Beograda. Glasnik Priroda muzeja (in Serbian), A(24), 127-154.

Anđelković, J. (1989). Tertiary fishes of Yugoslavia. A stratigraphical-paleontological study. Palaeontologia Jugoslavica, 38, $1-121$.

Arambourg, C. (1927). Les poissons fossiles d' Oran. Vol. 2. Matieriaux pour la carte geologique de l' Algerie 1re serie Paleontologie, 6, 1-298.

Bannikov, A. (2010). Fossil vertebrates of Russia and adjacent countries. Fossil Acanthopterygian fishes (Teleostei, Acanthopterygii) (pp. 1-244). Moscow: Russian Academy of Sciences, Borissiak Paleontological Institute, Geos (in Russian).

Baykina, E. M., \& Schwarzhans, W. (2016). Description of Karaganops n. gen. perrata (Daniltshenko,1970) with otoliths in situ, an endemic Karaganian (Middle Miocene) hering (Clupeidae) in the Eastern Paratethys, Swiss. Journal of Palaeontology. doi:10.1007/s13358-016-0115-4. 
Bianco, P. G., Bullock, A. M., Miller, P. J., \& Roubal, F. R. (1987). A unique teleost dermal organ in a new European genus of fishes (Teleostei: Gobioidei). Journal of Fish Biology, 31, 797-803.

Birdsong, R. S., Murdy, E. O., \& Pezold, F. L. (1988). A study of the vertebral column and median fin osteology in gobioid fishes with comments on gobioid relationships. Bulletin of Marine Science, 42(2), 174-214.

Brandl, W. (1931). Die tertiären Ablagerungen am Saume des Hartberger Gebirgsspornes. Jahrbuch der Geologischen Bundesanstanstalt Wien, 81, 353-386.

Brandl, W. (1953). Neue geologische Beobachtungen im Tertiärgebiet von Hartberg. Mitteillungen des Naturwissenschaftlichen Vereins der Steiermark, 1953, 108-111.

Bratishko, A., Schwarzhans, W., Reichenbacher, B., Vemihorova, Y., \& Corić, S. (2015). Fish otoliths from the Konkian (Miocene, early Serravallian) of Mangyshalk (Kazakhstan)-testimony of an early endemic evolution in the Eastern Paratethys. Paläontologische Zeitschift, 89, 839-889.

Brzobohaty, R., \& Gaudant, J. (2009). Gobius brevis (AGASSIZ, 1839), a gobiid fish with otoliths in situ (Pisces, Teleostei) in the Karpatian (Lower Miocene) of the Vienna Basin. Annalen des Naturhistorischen Museum in Wien, 111A, 245-256.

Brzobohaty, R., Nolf, D., \& Kroupa, O. (2007). Fish otoliths from the Middle Miocene of Kienberg at Mikulov, Czech Republic, Vienna Basin: Their paleoenvironmental and paleogeographic significance. Bulletin de l'Institut royal des Sciences naturelles de Belgique, Sciences de la Terre, 77, 167-196.

Brzobohaty, R. \& Stancu, J. (1974). Die Fischfauna des Samatien s. Str. In: Papp, A.- Marinescu, F.- Seneš, J.: M5, Sarmatien s. str.. Chronostratigraphie und Neostratotypen, 4, 492-515.

Carnevale, G., Bannikov, F. A., Landini, W., \& Sorbini, C. (2006). Volhynian (early Sarmatian s.l.) fishes from Tsurevsky, North Caucasus (Russia). Journal of Paleontology, 80, 684-699.

Chalilov, D.M. (1946). Kakraganskie i konkskie sloi severo-vostochnogo Azerbaijana (Karaganian and Konkian Beds of northeastern Azerbaijan). Doklady Akademii Nauk Azerbaijanskoy SSR, 2, 275-277 (in Russian).

Chalupova, B. (2008). Sarmatská rybia fauna z vrtu TPM-23B Smolenice (dunajská panva, Slovensko). Mineralia Slovaca (in Slovacian), 40, 53-58.

Dillon, A. K., \& Stepien, C. A. (2001). Genetic and biogeographical relationships of the invasive round (Neogobius melanostomus) and tubenose (Proterorhinus marmoratus) gobies in the Great Lakes versus European populations. Journal of the Great Lakes Research, 27, 267-280.

Djafarova, J. D. (2006). Otolity neogena Azerbaidjana (Neogene otoliths of Azerbaijan) (pp. 167). Baku: Nafta-Press (in Russian).

Economidis, P. S., \& Miller, P. J. (1990). Sistematics and freshwater gobies from Greece (Teleostei: Gobiidae). Journal of Zoology, $221,125-170$.

Fabricius, J. C. (1779). Reise nach Norwegen mit Bemerkungen aus der Naturhistorie und Ökonomie (pp. 1-388). Hamburg: Carl Ernest Bohn.

Friebe, J. G. (1994). Gemischt siliziklastisch-karbonatische Abfolgen aus dem Obere Sarmatium (Mittleres Miozän) des Steirischen Beckens. Jahrbuch der Geologischen Bundesanstalt, 137, 245-274.

Gierl, C., \& Reichenbacher, B. (2015). A new fossil genus of Gobiiformes from the Miocene characterized by a mosaic set of characters. Copeia, 103(4), 792-805.

Gierl, C., Reichenbacher, B., Gaudant, J., Erpenbeck, D., \& Pharisat, A. (2013). An extraordinary gobioid fish fossil from southern France. PLoS ONE, 8(5), e64117.

Härkönen, T. (1986). Guide to the otoliths of the bony fishes of the Northeast Atlantic (pp. 256). Danbiu ApS.
Harrison, I. J. (1989). Specialization of the gobioid palatopterygoquadrate complex and its relevance to gobioid systematics. Journal of Natural History, 23, 325-353.

Hoedemakers, K., \& Battlori, J. (2005). Fish otoliths from the Early and Middle Miocene of the Penedés (Catalunya, Spain). Batalleria, 12, 105-134.

Huyse, T., van Hout, J., \& Volckart, F. A. M. (2004). Paleoclimatic history and vicariant speciation in the „sand goby"group (Gobiidae, Telostei). Molecular Phylogenetics and Evolution, 32, 324-336.

Iljin, B. S. (1927). La table determinative des Gobiidae des Mers Noire et d'Azov. Information preliminare. Traveaux de l'Expedition pour l'exploration Des Mers Noire et d'Azov, 11, 128-143.

Iljin, B. S. (1928). Two new genera and a new species of Gobiidae from the Caspian sea. Reports of the Astrakhan Scientific Fishery Station, VI, 3, 1-13.

Iljin, B. S. (1930). Le systeme des Gobiides. Trabajos, Instituto Espanol de Oceanografía, 2, 1-63.

Jacobs, P., \& Hoedemakers, K. (2013). The round goby Neogobius melanostomus (Pallas, 1814) (Perciformes: Gobiidae), an invasive species in the Albert Canal (Belgium). Belgian Journal of Zoology, 143(2), 148-153.

Kessler, K. (1877). Les poissons vivant et se recontrant dans la region ichthyologique Aralo-Caspo-Pontique. Traveaux de'l Expedition Aralo Caspienne, VI, 1-360.

Kojumdgieva, E., \& Popov, N. (1988). Lithostratigraphy of the Neogene sediments in Northwestern Bulgaria (in Bulgarian, English abstr.). Palaeontology, Stratigraphy, Litology, 25, 3-26.

Kojumdgieva, E., Stanicheva, M., \& Dikova, P. (1982). Oporno profili po sondashi ha neogena ot severozapadna Bulgaria. Paleontology, Stratigraphy. Litology (in Russian), 16, 49-60.

Koken, E. (1891). Neue Untersuchungen an tertiären Fisch-Otolithen II. Zeitschrift der deutschen geologischen Gesellschaft, 43, 77-170.

Koleva-Rekalova, E. (2000). Sarmatian (Bessarabian) carbonate tempest Cape Kaliakra, North-East Bulgaria. Compts rendus de l'Academie bulgarie des Sciences, 53(5), 70-75.

Kováč, M., Andreyeva-Grigorovich, A., Bajraktarević, Z., Brzobohaty, R., Filipescu, S., Fodor, L., et al. (2007). Badenian evolution of the Central Paratethys Sea: paleogeography, climate and eustatic sealevel changes. Geologica Carpathica, 58(6), 579-606.

Kramberger, D. (1882). Die jungtertiare Fishfauna Croatiens. Beiträge zur Paläontologie Österreich Ungarns und des Orients, 2, 94-135.

Landau, B. M., Harzhauser, M., Islamoglu, Y., \& Marques da Silva, C. (2013). Systematics and palaeobiogeography of the gastropods of the middle Miocene (Serravallian) Karaman Basin, Turkey. Cainozoic Research, 11-13, 3-584.

Lombarte, A., Chic, O., Parisi-Baradad, V., Olivella, R., Piera, J., \& Garcia-Ladona, E. (2006). A web-based environment for shape analysis of fish otoliths. The AFORO database. Scientia Marina, $70,147-152$.

Malavsi, S., Gkenos, C., Leonardos, I., Torricelli, P., \& McLennan, D. A. (2012). The phylogeny of a reduced'sand goby' group based on behavioural and life history characters. Zoological Journal of the Linnean Society, 165, 916-924.

McKay, S. I. \& Miller, P. J. (1997). The affinites of European sand gobies (Teleostei, Gobiidae). Journal of Natural History, 31, 1457-1482.

Medvedev, D. A., Sorokin, P. A., Vasil'ev, V. P., Chernova, N. V., \& Vasili'eva, E. D. (2013). Reconstruction of phylogenetic relations of Ponto-Caspian gobies (Gobiidae, Perciformes) based on mitochondrial genome variation and some problems of their taxonomy. Journal of Ichthyology, 53(9), 702-712. 
Mestermann, K., \& Zander, C. D. (1984). Vergleichende osteologische Untersuchungen an Pomatoschistus-Arten (Gobioidei, Pisces). Zoologisches Jahrbuch der Anatomie, 111, 501-542.

Mikerina, T. B., \& Pinchuk, T. N. (2014). Distribution and source of dispersed organic matter in the Karaganian-Konkian-Sarmatian deposits of the Eastern Paratethys. Geology, Geography and global Energy, 4(55), 20-33.

Miller, P. J. (1981). Gobiidae. In FAO species identification sheets for fishery purposes, Vol. II (pp. 1-8). Eastern Central Atlantic.

Miller P. J. (1990). The endurance of endemism: the Mediterranean freshwater gobies and their prospects for survival. Journal of Fish Biology, 37(A), 145-156.

Miller, P. J. (2003) (ed.). The freshwater fishes of Europe, Mugilidae, Atherinidae, Atherinopsidae, Blenniidae, Odontobutidae, Gobiidae 1 (pp. 404). Wiesbaden: AULA Verlag.

Miller P. J. (2004) (ed.). The freshwater fishes of Europe, Gobiidae 2 (pp. 477). Wiesbaden: AULA Verlag.

Neilson, E. M., \& Stepien, A. C. (2009). Escape from the PontoCaspian: Evolution and biogeography of an endemic goby species flock (Benthophilinae: Gobiidae: Teleostei). Molecular Phylogenetics and Evolution, 52, 84-102.

Neseka, A. M., \& Bogutskaya, N. G. (2009). Fishes of the Caspian Sea: zoogeography and updated check-list. Zoosystematica Rossica, 18(2), 295-317.

Nolf, D. (1981). Révision des types d'otolithes de poissons fossiles décrits par R. SCHUBERT. Verhandlungen der Geologischen Bundesanstalt in Wien, 2, 133-183.

Nolf, D. (1985). Otolithi Piscium. In Schultze, H. P. (Ed.), Handbook of Paleoichthyology, Vol. 10 (pp. 145). England: Fischer.

Nolf, D. (2013). The diversity of fish otoliths, past and present. Brussels: Royal Belgian Institute of Natural Sciences.

Nolf, D., \& Brzobohaty, R. (1994). Fish otoliths from the Late Oligocene (Eger and Kiscell Formations) in the Eger area (northeastern Hungary). Bulletin de l'Institut royal des Sciences naturelles de Belgique, Sciences de la Terre, 64, 225-252.

Nolf, D., \& Brzobohaty, R. (2009). Lower Badenian fish otoliths of the Styrian and Lavanttal basins, with a revision of Weinfurter's type material. Annalen des Naturhistorischen Museum in Wien, 111 A, 323-356.

Nolf, D., \& Cappetta, H. (1980). Les otolithes de téléostéens du Miocène de Montpeyroux (Hérault, France). Palaeovertebrata, 10(1), 1-28.

Nolf, D., \& Cavallo, O. (1995). Otolithes des poissons du Pliocène Inférieur de Monticello d'Alba (Piemont, Italie). Rivista Piemontese di Storia naturale, 15, 11-40.

Paghida, N. (1962). Otolitele din Buglovianul Podisului Moldavenesc. Analele siintifice ale Universiatii "Al. I. Cuzci” din Iasi, sectiunea IIb (Stiinte naturale), Geologie-geografie (in Romanian), 8(2b), 13-20.

Pobedina, V. M. (1954). Iskopaemye otolity ryb miocenovyh otlozheniy Azerbaijana i ih stratigraficheskoe znachenie (Fossil fish otoliths from the Miocene deposits of Azerbaijan and their stratigraphical significance). Izvestia Akademii Nauk Azerbaidjanskoy SSR (in Russian), 10, 23-37.

Pobedina, V. M. (1956). Spravochnik po mikrofaune sredne- i verkhnemiocenovykh otlozhenii Azerbaidjana. In: V.M. Pobedina, A.G. Voroshilova, O.I. Rybina, Z.V. Kuznetsova (Eds.), Baku: Azerbaidjanskoe gosudarstvennoe izdatelstvo neftyanoi nauchno-tekhnicheskoy literatury (in Russian), 1-191.

Popov, S. V., Rögl, F., Rozanov, A. Y., Steininger, F. F., Shcherba, I. G. \& Kovac, M. (eds.) (2004). Lithological-paleogeographic maps of Paratethys. Courrier Forschungs-Institut Senckenberg, $250,1-46$.

Rado, G. (1968). Etude des otolithes sarmatiens de Copacel-Chijic (Bassin du Crisul Repede). Travaux du museum d'histoire naturelle "Grigore Antipa” 8(2), 581-585.
Radwanska, U. (1992). Fish otoliths in the Middle Miocene (Badenian) deposits of southern Poland. Acta Geologica Polonica, 42, 141-328.

Reichenbacher, B. (1988). Die Fischfauna der Kirchberger Schichten (Unter-Miozän) an der Typuslokalität Illerkirchberg bei Ulm. Suttgarter Beiträge zur Naturkunde, Serie B, 139, 1-53.

Reichenbacher, B. (1998). Fisch-Otolithen aus dem Karpat des Korneuburger Beckens. Beiträge zur Paläontologie von Österreich, 23, 325-345.

Reichenbacher, B., Gaudant, J., \& Griesemer, T. W. (2007). A late Burdigalian gobiid fish, Gobius brevis (Agassiz, 1839), in the upper Hydrobia Beds in the middle Upper Rhine Graben (W. Germany). Paläontologische Zeitschrift, 81(4), 365-375.

Rögl, F. (1999). Mediteranean and Paratethys. Facts and hypotesis of an Oligocene to Miocene paleogeography (short overview). Geologica Carpathica, 50(4), 339-349.

Rojo, A. L. (1985). Osteologia del chanquentes, Aphya minuta (Risso, 1810) (Pisces: Gobiidae). Boletino del Institut Espagnol del Oceanography, 2(1), 165-179.

Schubert, R. J. (1906). Die Fischotolithen des österr.-ungar. Tertiärs. III. Jahrbuch der kaiserlich-königlichen geologischen Reichsanstalt, 56, 623-706.

Schwarzhans, W. (1978). Otolith-morphology and its usage for higher systematical units, with special references to the Myctophiformes s. 1. Mededelingen van de Werkgroepvoor Tertiaire en Kwartaire Geologie, 15, 167-185.

Schwarzhans, W. (2010). The otoliths from the Miocene of the North Sea Basin (p. 352). Weikersheim: Backhuys publishers, Leiden and Margraf Publishers.

Schwarzhans, W. (2014). Otoliths from the Middle Miocene (Serravalian) of the Karaman Basin, Turkey. Cainozoic Research, 14(1), 35-69.

Schwarzhans, W., Bradić, K., \& Lj, Rundić. (2015). Fish-otoliths from the marine-brackish water transition from the Middle Miocene of the Belgrade area, Serbia. Palaontologische Zeitschift, 89(4), 815-837.

Schwarzhans, W., Carnevale, G., Bannikov, F. A., Japundžić, S. \& Bradić, K. (2016a). Otoliths in situ from Sarmatian (Middle Miocene) fishes of the Paratethys. Part I: Atherina suchovi Switchenska, 1973. Swiss Journal of Palaeontology. doi:10. 1007/s13358-015-0111-0.

Schwarzhans, W., Carnevale, G., Bratishko, A., Japundžić, S. \& Bradić K. (2016b). Otoliths in situ from Sarmatian (Middle Miocene) fishes of the Paratethys. Part II: Gadidae and Lotidae. Swiss Journal of Palaeontology. doi:10.1007/s13358-016-01145 .

Schwarzhans, W., \& Wienrich, G. (2009). Die Fauna des marinen Miozäns von Kevelaer (Niederrhein). Backhuys Publishers, Leiden, Margraf Publishers, Weikersheim, 5, 955-1185.

Simonović, P. (1996). Filogenetski odnosi evro-mediteranskih $i$ ponto-kaspijskih vrsta glavoča falange Gobii (Gobiidae, Perciformes) (p. 229). Doktorska disertacija: Univerzitet u Beogradu (in Serbian).

Stancu, J. (1970). Otolitele sarmatiene de la Soceni (BanatRomania). Dari de Seama ale Sedintelor 56 (1968-1968). Paleontologie (in Romanian), 3, 5-24.

Steindacher, F. (1860). Beiträge zur Kenntniss der fossilen Fischfauna Österreichs. Sitzungsberichte der kaiserlichen Akadademie der Wissenschaften, mathematisch-naturwissenschaftliche Classe, Abteilung 1(40), 555-572.

Steurbaut, E. (1984). Les otolithes de téléostéens de l'Oligo-Miocène d'Aquitaine (Sud-Ouest de la France). Palaeontographica, A, 186, 1-162.

Strashimirov, B. (1972). Otolity ot tarkhana na Severoistochna Bulgaria. Annuaire del'Ecole Supérieure des Mines et de Geologie (in Russian), Sofia 18(2), 301-313. 
Strashimirov, B. (1980). Otolithes du Tchokrakien de la Bulgarie nordorientale. Geologica Balcanica, 10(2), 61-70.

Strashimirov, B. (1981). Otolity ot karagana na Severoistochna Bulgaria. Palaeontology. Stratigraphy and Lithology (in Russian), 14, 19-28.

Strashimirov, B. (1982). Otolity ot badena na Bulgaria. Palaeont. Stratigr. Litol. (in Russian), 17, 13-37.

Strashimirov, B. (1984). Otolity ot dolnia sarmat na Severnaia Bulgaria. Palaentology. Stratigraphy and Lithology (in Russian), 20, 15-41.

Strashimirov, B. (1985a). Otolity ot srednia sarmat na Severnaia Bulgaria. Annual of the Highest Institute of Mining and Geology Sofia (in Russian), 31, 7-20.

Strashimirov, B. (1985b). Otolity ot gornia sarmat na Severozapadna Bulgaria. Annual of the Highest Institute of Mining and Geology Sofia (in Russian), 31, 21-36.

Suzin, A. V. (1968). Otoliths. In B. P. Zhizhchenko (Ed.), Micropaleontologicheskie metody stratigraficheskich postroeniy $v$ neftegazonosnych oblastiach (Micropalaeontological methods of stratigraphical researches in the oil and gas bearing regions) (pp. 74-77). Moskow: Nedra Press. (in Russian).

Thacker, C. E. (2013). Phylogenetic placement of the European sand gobies in Gobionellidae and characterization of gobionellid lineages (Gobiiformes: Gobioidei). Zootaxa, 3619(3), 369-382.

Thacker, C. E. (2015). Biogeography of goby lineages (Gobiiformes: Gobioidei): origin, invasions and extinction throughout the Cenozoic. Journal of Biogeography, 42, 1615-1625.

Thacker, C. E., \& Roje, D. M. (2011). Phylogeny of Gobiidae and identification of gobiid lineages. Systematics and Biodiversity, 9, 329-347.
Vakarcs, G., Hardenbol, J., Abreu, V. S., Wail, P. R., Várnai, P., \& Tari, G. (1998). Oligocene-Middle Miocene depositional sequences of the Central Paratethys and their correlation with regional stages. SEPM, Special Publication, 60, 209-231.

Verga, D. (1841). Descrizione di un Gobius frequente nelle lagune di Comacchio (Description of a very common Gobid in Comacchio lagoon). Atti della Terza Riunione degli Scienziati Italiani, 379.

Vrsaljko, D., Pavelić, D., Miknić, M., Brkić, M., Kovačić, M., Hećimović, I., et al. (2006). Middle Miocene (upper Badenian/ Sarmatian) Palaeoecology and Evolution of the Environments in the Area of Medvednica Mt. (North Croatia). Geologia Croatica, 59(1), 51-63.

Weiler, W. (1942). Die Otolithen des rheinischen und nordwestdeutschen Tertiärs. Abhandlungen des Reichsamts für Bodenforschung, 206, 1-140.

Weiler, W. (1943). Die Otolithen aus dem Jung-Tertiär SüdRumäniens. I. Buglow und Sarmat. Senckenbergiana Lethaea, $26,87-115$.

Weiler, W. (1949). Die Otolithen aus dem Jung-Tertiär SüdRumäniens; 1b. Ergänzende Tafeln zu den Otolithen des Buglow und Sarmat. Senckenbergiana Lethaea, 30(4/6), 291-293.

Weiler, W. (1950). Die Otolithen aus dem Jung-Tertiär SüdRumäniens; 2. Mittel-Miozän, Torton, Buglow und Sarmat. Senckenbergiana Lethaea, 31(3), 209-258.

Whitehead, P. J. P., Bauchot, M. -L., Hureau, J. -C., Nielsen, J. \& Tortonese, E. (1984-1986). Fishes of the North-eastern Atlantic and the Mediterranean (pp. 1473). Paris: UNESCO. 